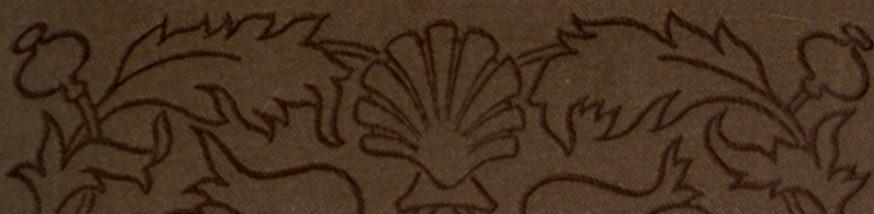

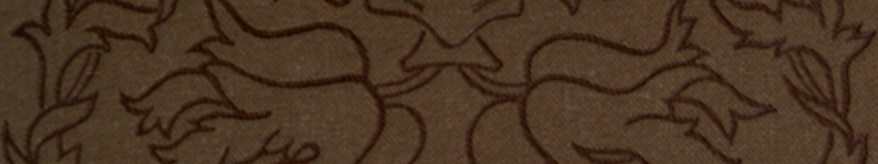

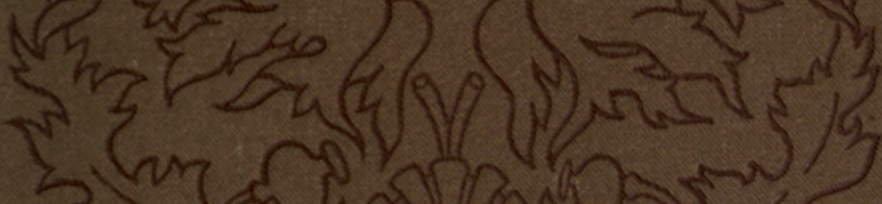
है SीP GLIMLSES
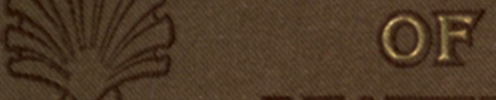
NATUURE
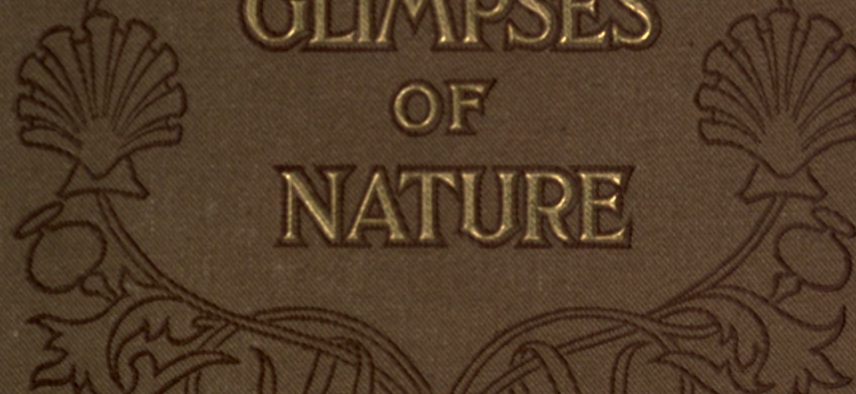

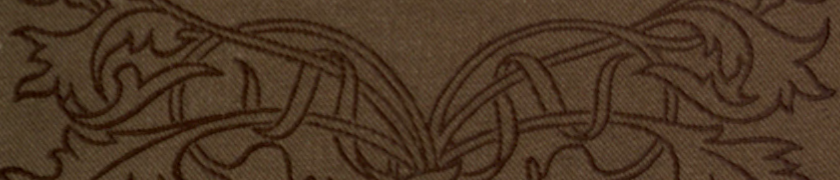

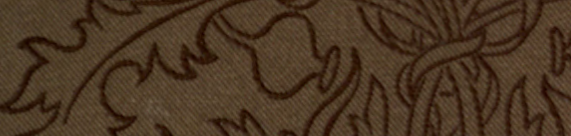

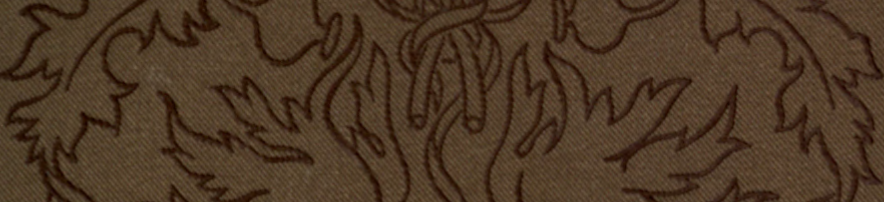
a का यकित है। 


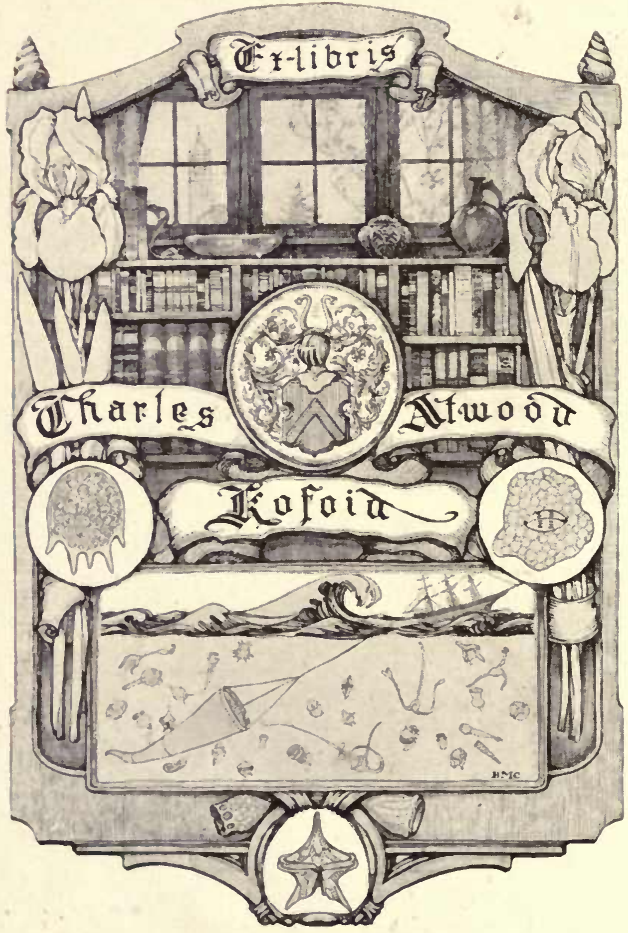




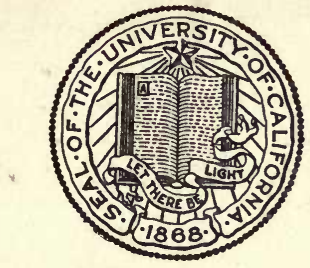

THE LIBRARY OF THE UNIVERSITY OF CALIFORNIA

PRESENTED BY PROF. CHARLES A. KOFOID AND MRS. PRUDENCE W. KOFOID 



\section{GLIMPSES OF NATURE}

BY

\section{ANDREW WILSON, F.R.S.E., F.L.S.}

LATELY LECTURER ON ZOOLOGY, EDINBURGH MEDICAL SCHOOL AND EXAMINER, FACULTY OF MEDICINE, UNIVERSITY OF GLASGOW COMBE LECTURER ON HEALTH

LECTURER TO THE GILCHRIST EDUCATIONAL TRUST

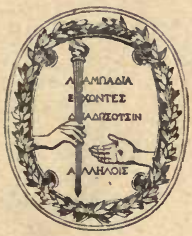

WITH THIRTY-FIVE ILLUSTRATIONS

NEW YORK

HARPER \& BROTHERS, FRANKLIN SQUARE I 89 I 

W5

Bial.

Lib.

TO

$L U A G$

BEST OF FRIENDS 



\section{PREFACE.}

THE papers which compose the present volume are reprinted from the Illustrated London News, to whose proprietors I have to acknowledge the courtesy which permits me to reproduce some of my contributions to its pages. The book really owes its origin to the suggestion of the late Mr. J. L. Latey, the genial editor of the News, whose memory will be kept green by many another contributor besides my humble self. Mr. Latey had frequently been asked if the papers entitled "Science Jottings" were likely to be reprinted, while I myself have also received numerous inquiries to the same effect. I trust, therefore, I may find myself in the happy position of an author whose book is anticipated in some quarters, and whose labours, despite their shortcomings, are certain of a welcome from the known friends, and still more from the many unknown friends, whom I am privileged to address week by week in the "Science Jottings" of the News. It is late in the day to apologise for presenting a series of popular science papers for public approval. May I add, however, that the articles 
included in this volume in no sense lay any pretensions to fulness of detail? They are intended to be suggestive rather than informatory; and as such, may perchance serve to whet the appetite of my readers for more solid and more extensive knowledge of the fair world in which we dwell. One can surely hope for no higher result for his labours, than that they may be instrumental in stimulating thought, and in inducing a closer acquaintance with Nature in her ever-varying moods and tenses-a study wherein the wisest of men have found comfort in sorrow, and a grateful relief from the ills and worries with which human existence is apt to be afflicted. 


\section{CONTENTS.}

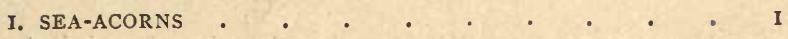

II. THE NIGHT LIGHTS OF THE SEA • • • . $~ 7$

III. BUILDERS IN THE SAND • • • • • • 12

IV. OYSTERS • . . . . . . . . . 18

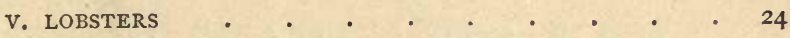

VI. SPIDERS • . . . . . . . . 30

VII. STARS AT LAMLASH • • • • • • 35

viII. A CUTTLE-BONE • • • • • • • • 42

IX. A CURIOUS COLONY . . . . . . . 49

X. A BIT OF SPONGE • • . . . . . . 54

XI. "THE KING OF FISHES" . . . . . . 60

XII. STARFISHES • . . . . . . . 65

XIII. SEA-URCHINS • • . . . . . . . 7 I

XIV. SOME MIXED RELATIONSHIPS. • . . . . 77

XV. A REMARKABLE HISTORY . . . . . . 83

XVI. A DISPLAY OF ENERgY . . . . . . . 88

XVII. SOME PLANT GROUNDLINGS • • . • • • 94

XVIII. SOME CURIOUS WAYS OF PLANTS . . • • . 99

XIX. THE FERTILITY OF NATURE . . . . . . 104

XX. DANDELION DOWN • . . . . . . . IO9

XXi. THE Mistletoe BOUGH. . . . . . . II4

XXII. HOLLY BERRIES . . . . . . . . 120 
XXIII. SOME MICROSCOPIC FRIENDS

XXIV. SOME MICROSCOPIC MUMMIES . . . . . I3O

XXV. THE WORKERS OF THE BODY . . . . . I35

XXVI. GERMS : GOOD AND BAD . . . . . . I40

XXVII. A CONFUSING CASE • . • • • . . I45

XXVIII. FLIES • • • . . . . . . . I50

XXIX. A GOOD STARVE. . . . . . . . I55

XXX. OTHER SENSES THAN OURS . . . . . I60

XXXI. SOMETHING NEW ABOUT THE EAR . . . . I65

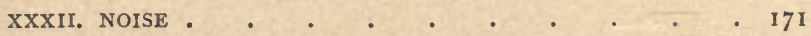

XXXIII. THE PROBLEM OF LIFE . . . . . . I76

XXXIV. WHAT IS MESMERISM? . . . . . . I $\mathrm{I}$

XXXV. THE CASE OF COLONEL TOWNSHEND . . . I 86

XXXVI. THE SPLEEN + . . . . . . . . I9I

XXXVII. THE TONGUE AND SPEECH. • • • . . 196

XXXVIII. TOWN LIFE AND ITS EFFECTS . . . . . $20 I$

XXXIX. A RAINY DAY • • . . . . . . 206

XL. THE LESSONS OF A QUARRY . . . . . $2 I I$

XLI. THE STORY OF THE ISLANDS . . . . . 216

XLII. THE IIFE OF ISLANDS • • • • • . 221

XLIII. A CORNER OF KENT . . . . . . . 226

XLIV. THE INROADS OF THE SEA . . . . . 231

XLV. THE GROTTOES OF HAN . . . . . 236

XLVI, COAL AT DOVER. . . . . . . . 242 


\section{ILLUSTRATIONS.}

FIG.

PAGE

I. Balanus porcatus : an Acorn-shell, seen from top . $\quad$ - 2

2. Balanus Hameri : a Sea-Acorn viewed from the side . . 3

3. Development of Crustaceans • . . . . . 5

4. Noctiluca . . . . . . . . . . 10

5. Terebella and its tube. . . . . . . . . I3

6. Sabella and its tube, showing the plume-like gills . . . 16

7. Dahlia Wartlet Anemone (Tealia crassicornis) . . . 19

8. Joints of Lobster's Body . • . . . . . 26

9. Diagram of Lobster . • • • • • • • 25

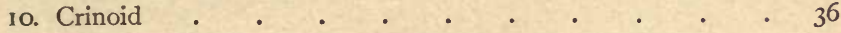

II. Rosy Feather Star, and stalked young • • • • • 39

12. Cuttlefish shells • • • • • • • • • 43

13. Octopi or "Devil-fishes" . . . . . . . 44

14. Pearly Nautilus Shell . . . . . . . 46

15. Spirula and its shell . . . . . . . 47

16. A "Sea-fir" . . . . . . . . . 50

I7. Sea-fir, largely magnified, showing cups and egg-capsule . $5^{\text {I }}$

18. Development of a Sponge (Olynthus) . • • • 55

19. Starfishes . . . • • • • • 67

20. An Echinus climbing on glass of an aquarium . . 73

21. Gall insect (Cynips kollari) . • • • . . 79

22. Galls on oak-leaf: "spangles" and "button galls" . . 8I

23. Fern-frond: Woodsia ilvensis . . . . . 97

24. Dandelion Down . . . . . . . . 110

25. Mistletoe (Viscum album) flower and fruit . . . . II6

26. White Corpuscles of the Blood . . . . . . 127

27. Rotifer: Male . . . . . . . 132 
FIG.

28. Rotifer: Female

29. Saccharomyces cerevisice

30. Bacillus anthracis

3I. Volvox

32. The Common House-fly (enlarged)

33. The Ear in Vertical Section

34. The Inner Ear

35. Cave into which the Lesse disappears .

132

I4I

I43

I47

- 153

- 166

I69

238 


\section{GLIMPSES OF NATURE.}

\section{I. \\ Iea $=\mathfrak{H}$ corns.}

Yesterday, as I came from my dip in the sea, I had to scramble barefooted over a ledge of rock to the safe haven wherein I had deposited the suits and trappings of the outer man. The surface of the rock, which appeared so smooth viewed from a distance, was, in reality, a veritable place of torture, for it was studded with small sharp shells, contact with which rendered my scramble somewhat of a penitential pilgrimage in its nature. The candid friend who heard my plaint was immediately prepared with a hundred questions regarding not only the nature of these shells, which encrust the rocks everywhere, but concerning the "use" or uselessness of such minute and feeble folk in the world at all. There is much difficulty experienced at times in replying to commonplace questions. What the shells are, is a matter easily enough disposed of; what use they may subserve in the world at large, is a point not so easily determined.

After all, is this question of "use" really one which need concern us greatly in our studies of life? 
I trow not; for it surely indicates by no means a lofty conception of things if we are perpetually to speak and think of living beings as we should talk of the items in a store. Each organism, like the smith in "The Fair Maid of Perth," fights for its own hand in the struggle for existence. If in the course of its fight, it aids or opposes the interests of other living things, it will receive benefit or incur failure in a meed corresponding to its own ways and means. This is really the true philosophy of natural history study. To "consider the lilies" as if they were mere contrivances for human ends and "uses" is a tolerably small-minded fashion of regarding the children of life. To know something of their histories, structure, and relationships, and thereby to learn how life jogs along its primrose way (or the reverse), is in itself an education worth much seeking after and much painstaking care.

A truce to philosophy, however. On a piece of stone close by I discern a colony of these encrusting shells. Into the pool I drop the stone and its tenants.

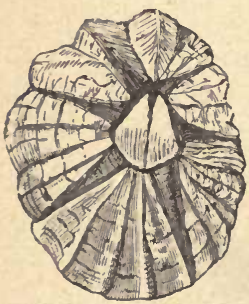

Fig. 1.-Balanus porcatus : an AcornShell, seen from the top.

Watch what happens. The upper end of each little shell (fig. I) uncloses, as does a trap-door, and forth issues a set of "feelers," which remind you of delicate feathery plumes. Now, backwards and forwards in the water wave these plumes, expanding to the full in their outward movement, and then gracefully folding inwards, as a preliminary to their next and succeeding sweep.

These plumes, moreover, you would find, on microscopic examination, to be abundantly provided with 
hairs, converting them into veritable brushes, which, like the proverbial broom of Mrs. Partington, are really employed in sweeping the waters. You can guess the use of these plumes, though you may not so readily arrive at a first conception of their nature. They are the commissariat officials of the sea-acorn's economy-for under this name you must know the shells which encrust the rocks, stones, and oysters everywhere. By aid of its "feelers," the sea-acorn sweeps into its mouth the food-particles on which it lives.

A most effective brush must these plumes constitute, seeing that they number some twenty-four in all, each of the original twelve being double in nature. It is more than probable that these organs, forming what has been named the "glass hand" of the sea-acorn, also serve for breathing purposes, although inside the shell we certainly light upon structures believed to represent gills. Still, from their incessant waving in the clear water, and from the obvious opportunity thus afforded of bringing the blood of our

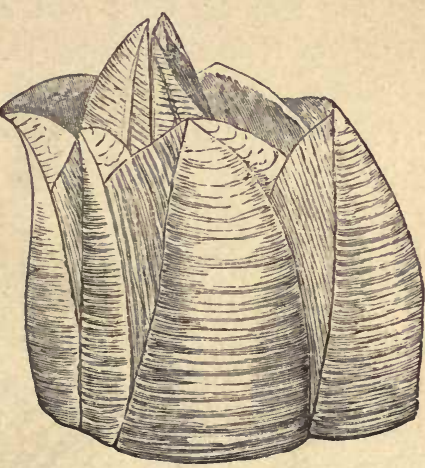

Fig. 2.-Balanus Hameri : a SeaAcorn viewed from the side.

acorn in contact with the vivifying oxygen of the sea, we may assume with safety that the plumes of the "glass-hand" play a part, at least, in renewing the vital fluid of the miniature frame.

I tap lightly on the stone which contains our colony of sea-acorns, and in a moment you observe 
each set of plumes is withdrawn, while the trap-doors of the shell are closed with something which reminds you of a defiant snap. This observation, then, proves to us that the acorn possesses means for maintaining relations with the outer world-or, in plain language, that it includes a nervous system among its personal belongings. If you could dissect the body completely, you would find comprised within the shell a perfect digestive system for the assimilation of food. We cannot presume to gauge perfection of organs by the standard of size in the world of life, and the seaacorn race illustrates this contention in an apt fashion. Nor can you argue that simplicity of structure always means lowness of origin, for the history of how your sea-acorn came to be what it is, proves the necessity for our looking backward as well as forward in the matter of living histories.

Sea-acorns are in reality poor relations of the barnacles which you have seen coating the sides of ships in the graving-dock. The barnacle possesses a stalk, while the acorns want that appendage; and therein lies the principal difference betwixt the races. But both acorn and barnacle in turn show relationships to other and widely different animals. That crab which you see perambulating in the pool in his own lop-sided fashion is an aristocrat of the barnacle class. So also is the lobster, and the shrimp, and the other shelled animals with legs. How do I know this? you inquire. Listen, and you shall be more than satisfied with the correctness of my statement.

The sea-acorn in due season develops eggs, and these are liberated from the parent-shell and sent forth into the world of waters to start life on their own account. Each egg develops at first into a 
widely different animal from the acorn itself. In the days of its infancy the sea-acorn appears as a minute oval body, possessing a single eye. A shell covers its back; a tail appears; and from the front of the body there grows a pair of feelers, while from its sides project two pairs of legs. Internally a digestive system soon appears; and, thus provided, the young acorn swims merrily through the sea. Then comes the moulting stage.

Increase of growth is impossible to a shelled animal
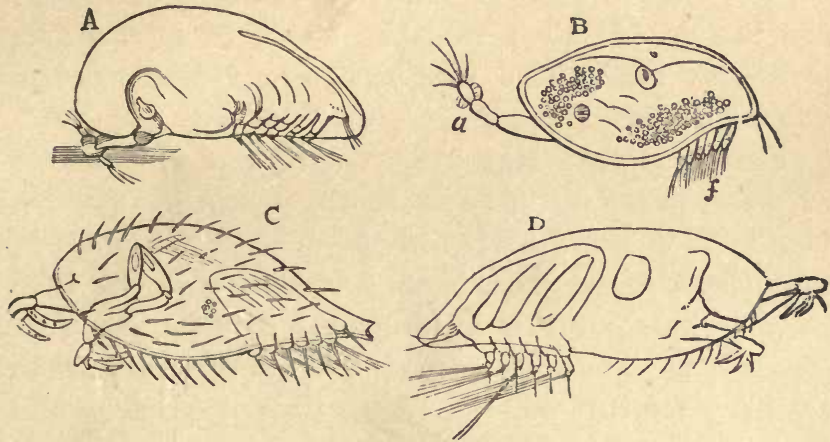

Fig. 3.-Development of Crustaceans.

$\mathrm{A}$ and $\mathrm{B}$ are stages in Barnacle development : $\mathrm{C}$ and D are stages in the development of a lower member (Sacculina) of the Crustacean class.

unless the old shell be changed for a new one. Hence the reason for the moults which the infant animal exhibits. By-and-by, a further stage is reached when the young acorn attains a still more perfect shell composed of two distinct halves or pieces. The front pair of feelers ( $a \mathrm{~B})$ have increased in size ; but the two original pairs of legs have been cast off, and are replaced by six pairs of short, jointed feet. The tail also develops swimming appendages; and two 
eyes succeed the Cyclopean and earlier state of things.

In this condition, the young acorn exactly resembles certain of the adult water-fleas; and it is also to be noted that in the course of their own development the crab and lobster tribes exhibit stages which parallel the condition of the acorn just described.

Then the days of its youth come to an end. The feelers grow large and strong; and a cement is poured out from them which fixes the hitherto free-swimming body to rock or shell (fig. 3, A.) The eyes disappear, and the double shell vanishes away, to become replaced by the conical limy structure you see before you on the stone.

Last of all, the legs are changed into the plumes or glass-hand of the adult acorn, which, to use the words of a great naturalist, is thus only a kind of degenerate crab, fixed head downwards as we have seen in its shell, and kicking food with its legs into its mouth. Thus we learn that to know an animal in reality we must understand its becoming as well as its being. The sea-acorn's history, in this sense, is a lesson which holds good and true of all other living things. 
II.

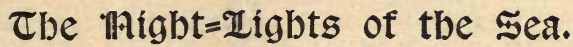

IT is a calm, clear night, this, on which the good ship Adelaide lies at Parkeston Quay, Harwich, blowing off her superfluous energy in the shape of clouds of steam, while waiting for the Rotterdam contingent of passengers, who are being hurried down at sixty miles an hour speed from Liverpool Street. Presently, there is a flash of light seen now and then along the fen-sides which mark the near approach to Harwich, and with a muffled roar the great engine, followed by a goodly array of carriages, comes to rest under the full glare of the electric lights of the station. Then the carriage-doors open, and the vehicles belch forth their crowds, who hurry down the wooden slope to the quay-side.

Forward go the passengers for the "Ankwork's package," as Mrs. Gamp named the prototype of the fine Antwerp steamer of to-day. The Rotterdam boat lies aft on the quay. As I step on board and survey that crescent moon overhead, which a short time before at Claygate, in the garden of Surrey, was a full orb, and, as I contemplate the still clouds and the calm sea, I prophesy an even keel for the Adelaide on her coming voyage to the land of dykes. In truth, it is a lovely night; and when we have 
cast off our ropes and hawsers, and go half-speed ahead round that curve in Harwich Bay towards the open sea, one may well be excused if even a rhapsody on the moonlit sea flowed from lip or pen.

The whole seascape is a nocturne in moonlight. The twinkling lights of Harwich show up the darker background of hill and church spire in true Rembrandt fashion. Out in the bay the yachts and ships sleep peacefully on the bosom of the deep, and the rays of each twinkling lantern rise and fall with the swell. Away beyond, in the sea whither every dip of our paddles carries us fast, there are seen the lightships, each with its twinkling eye that gleams luminous for a moment and then vanishes away with the regularity of an unvarying mechanism.

The deck is still and quiet, although there is noisy clatter of knives and forks in the saloon below. On the steamer's bridge you can discern three or four dark figures - those of our guides through the deep. Soon things settle down to a still more monotonous state than before. Save for the throbs of the engines, and the occasional rattle of the steam steering gear, all is at rest, and the good ship ploughs her way easily over the calm waters of the sea.

One may sit on the paddle-box on this autumn night revelling in the beauty of the seascape around. Far away, the lightships continue their mechanical illumination of the deep; but as you glance over the ship's side into the sea you become aware that the lights of man's contriving are not the only illuminations which meet the eye to-night. Watch the waves which spring into existence as the bow of the steamer ploughs the main. A long crest of foam passes away at a wide angle from the bow, and loses itself in the 
wash of the paddles behind. What is that strange gleam of light which ever and anon you see tipping the foam-crest with a weird effulgence and an uncanny gleam?

As the moon passes behind a cloud, and the night grows darker for the obscuring of the Queen of Night, this strange light on the waves literally glows with its fiery sheen. You are fortunate to-night in that you can see this "phosphorescence of the sea," as it is named, in all its splendour. Look how every fleck of spray seems tinged with a radiance as of jewelled kind. Flashes of lambent fire play among the foam, and now and then a long ripple of flame shoots along the whole course of the wave that rushes aft from the bow.

Suppose you could lift a bucket of water from the sea to-night, and that in your deck-cabin you had your microscope in full array, let us endeavour to see what such a scrutiny of the waves would tell us about the cause of the phosphorescence of the deep. The water would be seen to be alive with animalcules, each the mere fraction of an inch in length. Closely studied, each animalcule - the Noctiluca by name-is in shape not unlike a bean. It is curved or convex on its outer margin, while on the inner side it is concave and deeply indented.

On the hollowed side it bears a single tentacle or "feeler," which is in active movement. Of structure or organisation this Noctiluca possesses little or none. It is an animalcule belonging to one of the lowest grades of animal life. Its substance consists of that life-matter of which, under the name of protoplasm, you have heard so much in days gone by. It is a little living speck, and nothing more. Here and 
there it seems to exhibit spaces and gaps in its substance, and you may discover traces or beginnings of definite tissues in the soft mass whereof it consists.

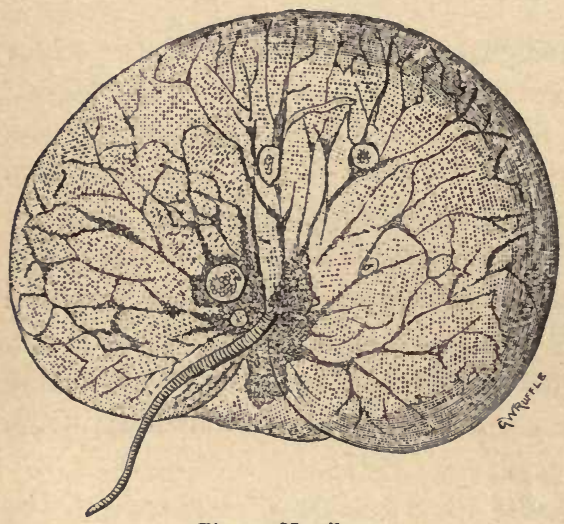

Fig. 4.-Noctiluca.

This, then, is the Noctiluca, which emphaticallyconst it utes the "night-light" of the sea.

Swarming in myriads in the waters of the ocean, these animalcules, under favourable conditions of heat and other phases relating to their vital activity, give forth the strange weird gleam you see shooting along the crest of the waves. You can recall Coleridge's lines with apt force, when on this quiet night you sit and watch the play of phosphorescence on the sea :-

Beyond the shadow of the ship, I watched the water-snakes ;

They moved in tracks of shining white,

And when they neared the elfish light

Fell off in hoary flakes.

Beyond the shadow of the ship, I watched their rich attire; Blue, glossy green, and velvet black, They coiled and swam, and every track Was a flash of golden fire.

How and why these and other animals exhibit a phosphorescent light is a problem towards the solution of which science has, at least, advanced within reasonable distance. The Noctiluca is undoubtedly the cause 
of the diffused phosphorescence of the sea. The myriads of animalcules give to the ocean the appearance of a universal effulgence. But other animals are solitarily phosphorescent. Jelly-fishes, and their neighbours, the "Venus's girdles," show such a light. Some fishes also possess phosphorescent qualities; and, as regards insects, our familiar glow-worm has only to be named to call to mind an analogous example of light-producing powers. The why and wherefore of the phosphorescence lies in a nutshell.

You have only to hark back to a great and leading principle in science to find the clue to the mystery. That one force of Nature can be transformed into an equivalent of another force, is plain language of science. Fire a bullet at a target. When the bullet hits the mark its motion has become transformed into an equivalent of heat. Similarly out of motion you may get electricity, and out of electrical motion of another kind you may get light. So is it with life and living structures. So much of vitality, or life-force, goes to produce motion, and so much in particular cases (that of our Noctiluca included) to produce light. Just as by the discharge of its nerve-force into its electrical organ, a species of skate produces electricity, and gives you a powerful shock; so your animalcule, transforming a modicum of its life-force in a special fashion, gives you "the night-light of the sea."

But it is time to draw rein to these thoughts. Here is the lightship close on our starboard bow. "To rest we repair," as the old song has it; yet the animalcules will not cease their phosphorescence, even when the faint rays of the morning have brightened "more and more into the perfect day." 


\section{III.}

\section{Jouilders in the sand.}

THE near approach of the winter season is heralded this morning by the chill east wind and the thin ice which coats the pools left by the receding tide a few hours gone by. To-day we are strolling along a sandy flat of Scottish sea-coast, not far removed from that engineering triumph, the Forth Bridge itself. Pleasant memories of bygone days revive in the mind when we approach the "Shell-bed" - as the sandy stretch is termed. One constant feature of the beach has won for it the familiar "Ferry" name. The sea-line at high-water mark is always indicated by a clear, glistening line of shells, whole and broken alike, torn from the sandy depths below, and brought up by the play of the waves. I presume the tides and currents of the bay cast up the shells on the beach and favour the formation of this unbroken and uniform line of shell-débris.

Beyond this high-water mark you come upon the sand-dunes of the coast. The tough grasses which find a home and habitation in the sand bind the loose wind-blown particles together, and thus aid in the work of land-making. The "Shell-bed" on the Firth of Forth reminds me of a pleasant prospect in scenes far removed from this Scottish estuary. 
Away in Devonshire, and stretching from Dawlish towards Exeter, is such another sandy beach as that which lies before us this winter morning. Only, the Devonshire coast wants that background of pines that stands out so prominently against the light brown of the sand. But for the funereal setting of its firs and pines, and for the hills of Fife in the foreground, the Dawlish prospect might be regarded as being closely imitated on these northern shores.

We descend from the shelly ridge towards the lower confines of the beach. In a moment or two, we find ourselves amid the damp sand which, cut into miniature valleys by the rills from the land, betokens the recent $\mathrm{ebb}$ of the sea. As we walk over the yielding sand we see the burrows of the Solens or "razor-shells," whose cast-off products litter the shore at the high-water line. Your "razor-shell" is a skilful burrower, and by means of his fleshy foot contrives to mine swiftly and effectively below the surface of the sand, so that pursuit and capture, save by means of the fisherman's iron hook, is a sheer impossibility.

As we traverse the beach nearer still to the sea, we notice the débris thrown out by the worms, which after airing themselves amid

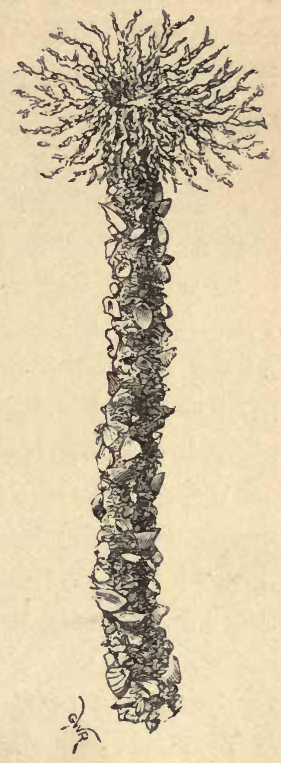

Fig. 5.

Ter ebella and its tube. the waves when the tide is in, turn tail and tunnel downwards. They are, in reality, living tunnel- 
makers, for they pass the sand through their bodies as they work below, and hence you see the internal casts of their digestive systems in the familiar "sandworms," or coils, which litter the shore. These are the "fairy ropes" of the children.

The old legend of Michael Scott, wizard par excellence, tells us how, having engaged the Evil One as a servant, he found it a condition of his own safety to keep his diabolical servitor fully employed. The proverbial mischief into which idle hands are said to fall, was therefore averted by Michael the Wizard setting his fiend to weave ropes out of the sea-sand; and the futile labours of his Satanic Majesty, adds the legend, are to be seen after every receding tide.

There, in the distance, is a fisherman digging in the sand for bait. When you look into his can you see a wriggling mass of green and brown worms, each with a big thickened head and a narrower body. This is the lobworm, dear to the hearts of sea-fishers. Along the sides of its body you see the gills existing in the shape of curious tufts, which are really complex loops of blood-vessels, wherein the impurities of worm-organisation are got rid of, and its blood purified by exposure to the oxygen of the sea. But the "lob" is not an architect in any sense. Scan the sand around you, and notice that, rising from its smooth surface, your eye can detect numberless feathery-like tufts.

You borrow the fisherman's spade, and remove at one operation half-a-dozen or more of these tufts. Then when you single them out from among the mass with your fingers you see that each tuft is really the top of a tube, and that inside this tube 
dwells a worm-tenant which is doing its best to escape into the sand by the lower end of its dwellingplace.

This is the Terebella, a worm which ranks among the most common of all the architects of the sand. Look at the tube closely (Fig. 5). Its composition is varied enough. It consists of a series of odds and ends in the way of particles, and the heterogeneous materials of the tube account for the rugged appearance of the structure. The bulk of this worm's house is built of grains of sand, but you also note how it has seized upon pieces of broken shells, and even minute pebbles as building-stones. These materials are all duly glued together by means of a natural marine cement, which resists the action of the water, and defies the damp to disintegrate the tenement of the Terebella.

The tuft at the top of the tube, which is modelled in sand, is really the outer investment or covering of the gills and feelers which the head of the worm bears. The gills are plume-like, and the feelers, or tentacles, act as purveyors in the commissariat department. They sweep food-particles into the mouth, and possibly filter from the sea or sand around, the matters necessary for the nutrition of the wormframe.

But in our shovelful of sand there are wormtubes of another description. You now disinter a tube of smoother and more regular aspect than those of the Terebella. This second tube is composed of sand particles alone, cemented together to form a symmetrical structure, which impresses us by contrast with the rougher build of the Terebella's dwellingplace. The smooth tube (Fig. 6) is the abode of 
the Sabella, another familiar worm-architect of our sandy shores. I know of nothing more beautiful than the plume-like gills of the Sabella-worm. They spring from its head-extremity, together with its

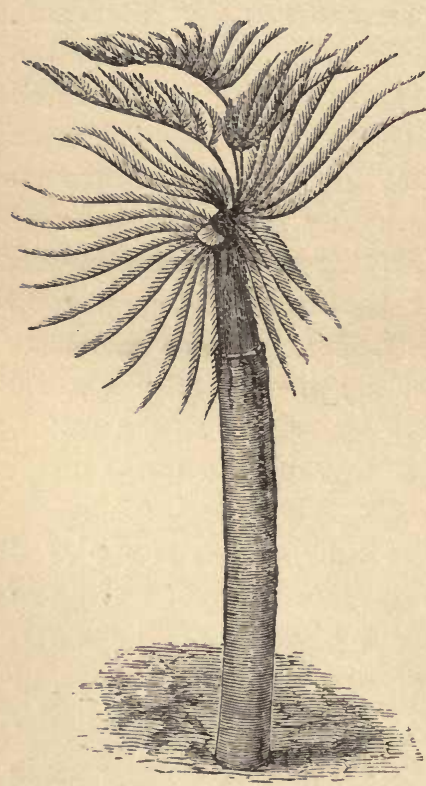

Fig. 6. - Sabella and its tube, showing the plume-like gills feelers, in curved array, and present us with truly feathery sprays, wherein the blood of the animal courses in closely-placed vital streams, to be exposed to the air contained in the native water of the worm.

Extremely sensitive are these gills and tentacles, as you may demonstrate in the case of yet another worm-architect. On this stone $I$ have picked up is a hard, dense tube of carbonate of lime, or, in plain language, hard chalk.

This is the Serpula's habitation. I place the stone and its tube in this rock pool. In a moment you see the beautiful gillplumes to be protruded from the tube, and to wave backwards and forwards in the water. This is the respiratory act or breathing-play of these animals, and the slightest touch sends the gills into the tube. Worm susceptibilities have been offended by the prying curiosity of humanity, and a natural plug (which is merely a thickened tentacle) closes up the mouth of the Serpula-tube until such time as its denizen, 
recovering from its fright, once more spreads its gillplumes abroad in the pellucid pool.

The worm-architects teach us a lesson in "habit" as applied to living nature. Each species adheres to its own way of life and materials - the Terebella to its shells and particles; the Sabella to its sand alone; and the Serpula to its limy investment. There is "more than meets the eye" in these persistent and regular building habits - more, perchance, than the mind can explain as things are. But at least we may discover that what we call "habit" in anything, is but a name for the regular repetition of ways, tendencies, and methods, which, at first of chance character, have become stereotyped to form the fixed history of living things. 
IV.

\section{Oysters.}

THAT window in the oyster-shop has always had a strange fascination for me, and I never contemplate the bivalves in its tanks without a sigh of regret that so much in the way of complex anatomy should glide over the human throat without exciting even a quiver to mark its sense of the social barbarity to which it has been subjected. It is curious, too, to note how different are the feelings with which we of these islands regard two nearly related molluscs-the oyster and the snail.

For the former we pay down cheerfully our twoand-six or three-and-six per dozen on Mrs. Driver's counter, while the dainty, vegetable-feeding snail (costing us, as imported, nothing like such prices) is eschewed as a continental culinary and gastronomic eccentricity. I suppose it always will be so in the matter of our food. We are terribly insular in a dietetic sense. I do not aspire to the free ideas of John Chinaman, who despises nothing which is edible, and to whom a rat or a dog may come with equal relish as does his trepang or bird's nest (for soup); but I do contend we might enlarge our daily bill of fare with great advantage to health and pocket alike. 
In my many journeyings to and fro over the surface of the earth it is my lot to sojourn frequently at hotels. I find the British waiter has invented a shibboleth which in the matter of breakfast is repeated over the length and breadth of the land. Inquire what there may be ready to offer you for the first meal of the day, and you are answered at hotel No. I, "Chop-fish-steak -ham-and-eggs, sir!" At hotel No. 2 it is, "Fish-chop-steak-ham-and-eggs, sir!"

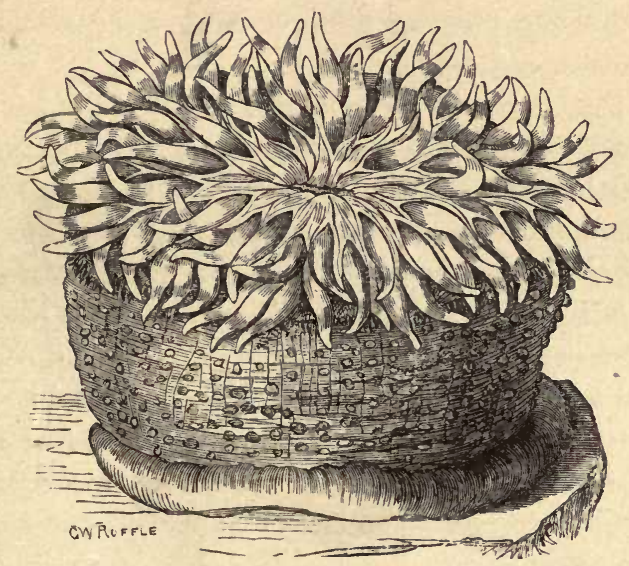

Fig 7.-Dahlia Wartlet Anemone (Tealia crassicornis).

At No. 3 it varies like the same old chimes-" Steakfish-chop-ham-and-eggs, sir!"-and so on, from Land's End to John o' Groat's, the refrain ceaseth never.

What this plaint of mine has to do with oysters may not, I confess, be apparent all at once; but my logical position is, luckily, secure. I contend that, as we have gone out of our (edible) way, ages ago, to devour the mollusc, we should progress a little 
further on the same (dietetic) lines. Why not enlarge and extend the British bill of fare? Here is a topic for my friend Mr. James Payn. The oyster must have been "a great departure" in its time. Imagine the attitude of the solid and eminently respectable Britisher who first swallowed an oyster. It was, in truth, a great feat; it led to a great innovation in food delicacies, and I trust it may be repeated in the case of many of the products of marine zoology as yet limited to the aquarium. The late Mr. Gosse used to relate how once upon a time he cooked and ate a sea-anemone.

In the days of my youth, fired with a strong emulation to imitate my masters in science, I went and did likewise. The experiment was not a success. The anemone (fig. 7) was tough, and required a nice sauce hollandaise, say, to make one fancy it was only cod-fish after all. Unfortunately I had to cook the animal myself (the head of the kitchen in those days refused to "mess about," as she put it, with "such filthy things"), and there were no directions in any of the estimable manuals of the culinary art at my command whereby I might be guided in my attempts in food-reform.

Later on I may "return to my anemone;" but it will be rather in a literary than in a culinary sense, I fear. You get nice fresh cuttlefish on the Mediterranean borders, and it tastes like nicely-done tripe. Everybody has had (or thinks he has enjoyed) frogs' hind-legs in Paris; but "you can never be sure," as the comic song has it, unless you go to the Halles Centrales and buy your frogs nicely skewered on those little bits of wood, each looking for all the world like a monkey on a stick. Anyhow, I always 
take mine oyster as a proof that once upon a time we did make a step in the direction of a fuller menu; and when one thinks of the endless reiteration of the "beef, pork, mutton," and of the "chop-fish-steakham-and-eggs, sir!" I can only hope (without being a Sybarite) that when we next enlarge our dietary I may be there to see-and to partake likewise.

Our oyster is designated, somewhat unfeelingly, I confess, in natural history text-books, "a headless bivalve." Whether it ever possessed a head or not, the sequel doth not show. I can certainly hie back, if you will, in oyster-history, and trace for you its development; but even in its early days there is no appearance of a head. Hence it is an inferior creature in this sense to your snail or whelk, which not only possesses a head, but contrives to see a good deal of the world in the course of its somewhat laboured peregrinations.

The oysters lying in Mrs. Driver's tank this morning are gaping widely enough. You might almost think they had died in the night; but when you tap the shell ever so lightly you notice how it closes with a somewhat leisurely but highly determined motion. Now, this observation proves two things to the inquiring mind. It shows, first of all, that the bivalve exhibits a quick appreciation of the "tapping at its garden-gate;" in other words, it is provided with a very distinct nervous system. Then, secondly, you observe that it possesses a powerful nuscle wherewith the shell is closed.

Look at the empty valve or shell from which you have just removed its tenant. You notice the oval impression on the inside of the valve showing where the muscle was attached, and you observe on the other and 
companion valve, the neighbour-impression. Between the two valves of the shell, then, there stretches this strong band of muscular fibres; so strong that it requires the deft hand of the oyster-opener to detach them. This muscle which closes the valves and kecps them shut is called the "adductor;" and while our oyster has but one, the mussels themselves possess two. It is a voluntary muscle this of the oyster, and quite as much at the command of the animal as your own biceps is placed under your behest.

But the adductor muscle of the oyster is not an organ which is frequently in use. If the shell is closed by its action, how, you inquire, are the valves opened? Look once again at the empty shell. You observe at its beak or apex the remains of a brownish substance. That is the "ligament" of the shell. It is an elastic band, which is put on the stretch when the shell is closed by the adductor muscle. If that muscle relaxes, you see what will happen. The elastic ligament will come into play, and by that elasticity will keep the shell open.

Now, as an open shell is the oyster's natural condition, we can note in this contrivance a saving of power. The shell is kept unclosed by the purely elastic and mechanical action of the ligament. The oyster has no need to bother itself over this duty. But it is when the more unusual work of closing the shell has to be accomplished that the vital and muscular act comes into play. Then the muscle acts, and "shuts up shop," so to speak, without delay. Nature is always economical in her distribution of power, and our oyster is kept gaping without the expenditure of any vital activity.

I may not linger to-day to tell you of the gills of 
the oyster (otherwise the "beard"), with their countless cilia, which waft in currents of water perpetually for food and breathing, and as perpetually sweep out these currents laden with the waste of the molluscan body. But perchance I have said enough to convince you that the oyster-shop exhibits many interesting problems in science in the contents of its tanks; and to suggest that, as oysters contribute largely to the material nutrition of mankind, they may also be found not less wholesome when regarded from an intellectual point of view. 


\section{V.}

\section{Iobsters.}

TO-DAY, in the fishmonger's shop, I beheld a large box of lobsters which the early morning train had brought from the far north of Scotland. They were packed into the box with that total disregard of whatever feelings the lower animals may possess which characterises man in his dealings with life below his own, whether it is represented by fowls in hencoops or by pigs or sheep in railway trucks. The seething mass of blue-black bodies encrusted with the white spiral shells of worms that build limy tubes, was " a sight for to see," as the old ballad has it. Lobsterlife seems to take its troubles with equanimity. Beyond an occasional squirming of a tail or flap of a feeler, all was quiet within the box. One veteran crustacean, perched in a coign of vantage above the others, was working his jaws-one of many pairs-as if still under the delusion that he was cosily nestling under his rock in the sea, and baling out the refuse water from his gills by means of the scooplike spoon wherewith he is provided for the purpose in question.

His great black eyes, each resting on a short stalk, were staring vacuously at the prospect before him. Mentally regarded, that prospect was not a cheerful one. "Out of the box and into the pot" might well 
parallel the frying-pan and fire simile as applied to lobster-life. In a few hours after I saw that big crustacean, I doubt not he was popped into his funeral urn. As I write, his nice blue-black shell will have changed into the bright red of the boiled animal-a colour seen, by-the-way, in the lobster of a certain classic picture intended to represent the native products of the sea as obtained in the miraculous draught of fishes.

By to-morrow, nothing will be left of him but his shelly armour. He will have perished, as has many a higher creature, in the work of making life brighter and better-in so far as lobster-salad can be said to aid that desirable end-and so runs the world away, little recking of the wonderful amount of vital complexity which it consumes even in its most commonplace fare.

A certain great naturalist has used the lobster-kind as the text or peg whereon to hang a very instructive book of natural history science. In truth, I know of no better task for a would-be naturalist than the attempt to discover the ways and works of lobster-existence. From its head to its tail the familiar crustacean is a living wonder. That it is a poor relation of the crab is a plain fact; although why a "poor" connection may not be quite so evident as is the relationship itself. This matter resolves itself into a question of tail and no tail. Early in life, crabs and lobsters are tailed animals. Then your crab shortens the appendage just named and tucks it up under his bodywhich, by-the-way, is all head and chest.

The lobster keeps his youthful tail throughout life, but poses as a lower animal than the crab in consequence. He is nearer the groundlings of his race, in 
other words, because of his tail ; and the crab, conversely, is his more modified and better developed cousin, because he has a higher nervous system and a more elevated and compact type of body. Not alone in crustacean life is this matter of tails a vital question. From frogs up to man, the disappearance of the tail

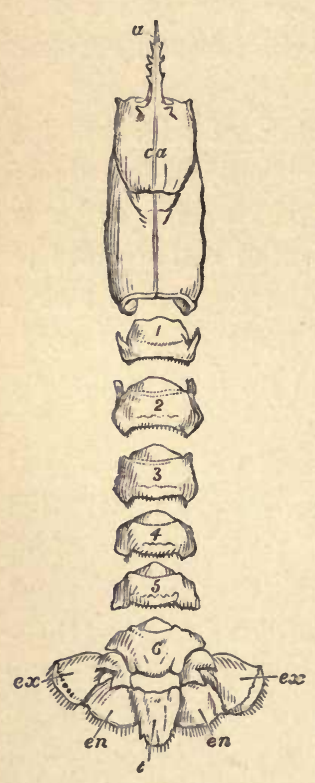

Fig. 8.- - Joints of Lobster's Body.

$\mathrm{C} a$ is the united head and chest : the numbers refer to the six joints of the tail ; the references $e x$ and $e n$ refer to the expanded appendages of the sixth joint forming the tail-fin ; and $t$ is the telson, or middle piece of the tail-fin. bears an important part in the history of the race. Heads are all very well in the race for superiority; but when there is a doubt at all in the matter of aristocratic position among the animal hosts, one may not go very far astray in crediting with a station of high degree, the being which has discarded his tail and, in a zoological sense, has come to the short-jacket stage of anatomical perfection.

That lobster of ours has in his body some twenty joints or segments, and there is not one joint which may not form food for reflection. Every joint is really a replica of every other joint, although, truly, you may require to dive into the intricacies of anatomy to trace out the likeness. Those six joints of his tail are, perhaps, the simplest of his frame. Below you observe that each possesses a couple of appendages called the "swimmerets," and to these appendages Mamma Lobster, as you may see, attaches her eggs, and constitutes 
herself a walking nursemaid by reason of this little piece of attention to maternal duties. Each pair of appendages is like every other pair; albeit, you find great variation in their shape and form. Those of the tail (ex en) exist each as a double-leaved structure set on a joint. If you look at the tail-fin, wherewith, aided by the big muscles of the tail, the lobster makes a forcible backward stroke in the water, you will discover that the fin consists simply of a pair of the swimmerets you see further forward on the body, broadened out, and having a little centrepiece $(t)$ set between them.

Go farther forward on the body and you come to the five pairs of walking legs. Now these legs, after all, are only altered swimmerets, in which the innermost leaf has grown big and foot-like, and has become encased in a limy shell. Further forward still, and you reach the "foot-jaws," which are half-way houses between jaws in front and legs behind. Then come the jaws proper, of which your lobster boasts three pairs. One pair is hard and thorny, the other two are softer in texture-but they are all really swimmerets, like those of the tail. Then in front of the jaws come the "feelers," and of these two pairs (fig. 9, $a b)$ exist. The lesser pair has two divisions, while the greater feelers, that project like huge horns, have only one division or part. These feelers, again, are only modified appendages, all corresponding to the simpler ones of the tail. Finally come the eyes; and the movable eye-stalks on which the eyes are set, correspond to the single joint by which the appendages elsewhere are attached to the body.

Now, if you ask me, "How one comes to all this certainty of knowledge?" I reply, because when the 
lobster is a mere baby, just out of his egg, or but little further advanced in his history, all the appendages resemble the swimmerets of the adult's tail. As he grows, those of the head change to form eye-stalks, feelers, and jaws; others become his foot-jaws, and others, again, his walking-legs; and only those of the tail retain their original form. It is not what things are, but what they have sprung from, that we trust to in science for the elucidation of their true nature; and the lobster is a good illustration of the manner in which many and varied organs of an animal's body arise out of one common stock-a feature which is repeated in the history of the whole animal.

Lobsters, thus, form a text, as I have said, for

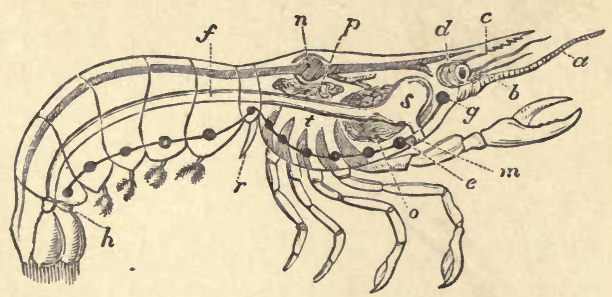

Fig. 9.-Diagram of Lobster.

teaching a great lesson in the value of watching an animal's development as a clue to its history. For the rest space fails me, at present, for the discussion of many interesting questions in crustacean life-as, for example, the inquiry, "How and what do lobsters see?" But of this matter more anon. Of gills (fig. $9, t)$ the lobster posseșses a full set, lying neatly packed away in the sides of his chest, and attached to the tops of his walking legs and foot-jaws.

A nervous system (fig $9, g, e$ ) he likewise possesses, lying on the floor of his body, like that of the insects, 
spiders, and centipedes, of which he is a distant connection. His digestive system, beginning at the mouth $(m)$, includes a stomach $(s)$, an intestine $(f)$, and a big liver. His heart $(n)$ he carries on his back. He has feelers and eyes, as we have noted; his ears exist at the foot of his lesser pair of feelers, and he possibly possesses a "nose" (physiologically regarded), for smelling functions, judging by his successful search after the "high" and odoriferous fish wherewith the lobster-traps are baited.

Altogether, the lobster is not to be despised as a lowly creature. Contrariwise; and, as his life is laid out for him, he possibly contrives to secure a full share of whatever corresponds in lower existence to the delights of higher or more sentient life. 


\section{VI. \\ કpioers.}

IN a corner of the kitchen window a very large specimen of the domestic spider has been engaged for a day or two past in constructing her domicile. I say "her," because, with whatever success in human life the female sex may fight the battle for equality with men, the question of woman's rights was solved in spider-life ages and ages ago. Your male spider is but a "puir body," as Northerners say when they express their sense of the inferiority of an acquaintance. Like certain human units (of the male sex) who are too much given to haunting their clubs, the male spiders are rarely seen "at home."

"The" sex is paramount in spider society, and, if any other argument were wanting to prove that "the grey mare is the better horse" among these spinners and weavers of lower life, one might find it in the fact that the ladies vastly exceed in size their husbands and male friends. There is yet another trait in the domestic life of the spider class which reveals a very curious phase of lower social history. Everybody has heard of those savage tribes (locality, South Seas, I believe) whose members deem it a bounden duty to brain their aged parents, and thus save the old folk from the trouble and bother of living on; while the economic 
side of this barbarous custom may, of course, also fall to be considered.

Something equally distressing has to be chronicled of the spiders. For it is certain that Madame Spider is, on the whole, a regular virago. She beats and mauls her husband, and, if police courts existed in spider society, the magistrates would have a busy time of it in the way of fines, imprisonments, and judicial separations. Not content with exercising marital authority, in the reverse order to that in which this species of command is usually exerted, Mrs. Spider has actually been known to make an end of her mate by slaying and, distressing to relate, by devouring him also.

One De Geer, who is quoted by Kirby and Spence, relates that he has seen the male spider "seized by the object of his attentions, enveloped by her in a web, and then devoured-a sight which," adds the sympathetic narrator, "filled him with horror and indignation." In a society where manslaughter or homicide seems to be the especial privilege of the female sex, we may cease to feel surprised at anything; and, having decried the vices, so we may extol the virtues of this curious race. Spiders, let us note, are not "insects," in any sense. People are too fond of calling everything an "insect" of whose rank in nature they are not quite certain.

From coral-polypes up to centipedes, all are "insects" to the uninstructed mind, and of course the spiders could hardly escape the imputation of being included in that class. But, while an insect has six legs, a spider has eight; and, while an insect has a pair of "feelers," a spider has none, as such. Again, in the absence of wings and in the manner of breathing, as 
well as in the fact that a spider's body is differently modelled from that of an insect, we see how rigidly the one group is marked off from the other. They are divergent branches of the same tree, no doubt, but their present-day distinctness is easy to be recognised. The spider in the kitchen is evidently a well-to-do member of her race. She is large and comely, and beautifully speckled and marbled with dark brown and yellowish white. Judging from her appearance, I should say she is a belle in arachnidan society, and, if one may deem that personal charms are enhanced by much activity and general liveliness, the spider in question must rank as a very Cleopatra of the tribe.

That geometrical web has given her a deal of trouble these last few days. I have watched her spin safetylines innumerable to keep the net from being displaced by the draughts of the kitchen window. It takes her only a minute or two deftly to fix a new cord, and she exemplifies to the full that expression of Pope's about "living along the line." How she spins her web it may be interesting to trace.

Like the silk-moth's caterpillar, or the mussel in the sea, which are also spinners and weavers, Madame Spider's silk-secretion exists within her body in a fluid state. It is made and secreted by certain silk-forming glands which end in the "spinnerets." These last are conical projections placed near the tail ; and comparative anatomy seems to teach us that the spinnerets really represent much-altered limbs. Each of these organs seems in its essential nature to be composed of a multitude of fine tubes, opening at the top of the spinneret. This, then, is the apparatus wherewith our spider weaves.

Let us see how the weaving is carried on. The 
silk, while within the glands, exists in a semi-fluid state; but when it is exposed to the air it becomes dried, or of a more tenacious consistence, and in this state is susceptible of being drawn out into a fine thread. Think for a moment what happens to melted wax or glue. So long as the heat is of sufficient amount, either substance remains fluid; but if we draw a little out of the pot on a piece of stick, exposure to the air hardens the wax or glue, and with a little dexterity we can produce the melted substance into a fine thread. This represents accurately enough how and why the semi-fluid silk of the spider becomes a dry thread when it is pressed out through the fine tubes of the spinnerets.

There yet remains the fact of the many threads which should issue from the spinnerets, and this fact is puzzling enough when you see that the spider really works with a single line. The single thread, however, is formed of the united strands which issue from the various spinnerets; yet, pause for a moment, to note the fineness of the spider's thread. You are accustomed in ordinary life to talk of "the gossamer thread" as the type of fineness; yet, what do you say. to the plain fact that this apparently single thread of utmost fineness is itself composed of hundreds of different threads?

Can the mind find a better illustration of the "indivisibility" of matter? I trow not; and when, in these latter days, we are given to talk and to think of atoms and molecules, and other ultimate forms of matter, it may be well if we give the spider's line a thought in passing as an illustration of life's success in dealing with the excessively thin and the marvellously fine. Other spiders than that of the kitchen 
window elaborate regular nests or tents, and use the silk-secretion as the lining thereof. The trap-door spider of Southern Europe will be familiar to many readers, and that strength as well as delicacy may be said to rank among the products of the race is easily proved, when we think of the tropical spiders which capture small birds in their "deceitful webs."

Our spider has been more than successful in her recent foraging expeditions. The autumn weather has chilled the flies, and has rendered them less active and easier prey than before. Madame Spider, from her dwelling-place, rushes along her web at the first intimation of an unintentional call from the fly world, and speedily her poison apparatus is brought into play for the extinction of the hapless victim.

The poison fangs of the spider are two curved hooks borne on what naturalists call the mandibles or big jaws. A poison gland supplies the virus, and our spider thus differs materially in this respect from a near relative, the scorpion, which carries its poison apparatus in its tail, and which, if report is to be believed, occasionally takes an insane fancy to commit suicide by plunging its own sting into its own back. Nothing so foolish ever happens in spider-life.

[Addendum.-As these pages are passing through the press, an observation has been published which seems to throw doubt on the generally received notion that the spider's thread is composed of many different strands. The observation requires confirmation, of course, but if correct, it will not lessen the interest which attaches to the spinning operations.] 


\section{VII.

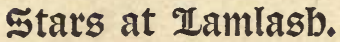

THIS quiet morning by the Clyde is the commencement of an ideal holiday of the lazy kind. Stretched on the greensward at Toward Point, one gives oneself up entirely to the dolce far niente style of existence, and to the dreams and fancies from which not even the most matter-of-fact life, so far as I can discover, is free. Active work is a thing of the past, and will be a thing of the future; for the present it is sufficient that books are closed awhile, lectures finished, and the gradgrind of life suspended.

In a few weeks we shall be back in the roar of the city : therefore, let us take the rest and content of things while we may. From Innellan we set out this morning, bent on a long stroll and on the exercise of our walking powers; but good resolutions melt away in the heat, and the grass at Toward is green and the air exhilarating; so we rest close by the lighthouse, and survey the prospect of hill and sea that never fails to charm, and rarely fails to convey a sense of graceful rest to the fagged city-dweller.

Quiet as it is at Toward, there is bustle enough not far away. Round the point at Rothesay, the Margate and Ramsgate of Scotland rolled into one, there is an eternal turmoil. Ardrishaig will be a 
busy place this day, with its vortex of tourists disembarking from the Columba's capacious decks, and embarking for the journey up the Kyles of Bute and onwards to Greenock and beyond. Tarbert you can see in your mind's eye, fussy and busy; and you can picture the Gaels on the Oban pier, pointing with their fingers, as if they all exhibited some maledictory frame of mind, to secure engagements for carriage of baggage from steamer to town. Inverary, too, will

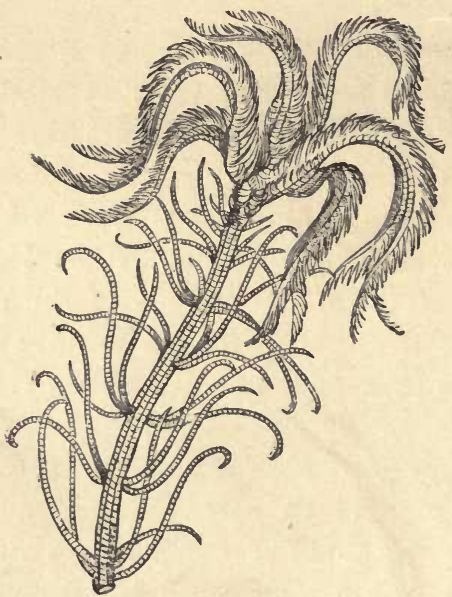

Fig. ro.-Crinoid.

not be behind in its bustle and stir when the Lord of the Isles comes alongside the pier; and little Strachur itself can put on a very respectable air of importance when from the steamer the tourists pour forth to coach it overland.

Other scenes, too, you can picture for yourself, as the steamers pass by in quick succession. The whitefunnelled Ivanhoe is off on her Arran trip, and the less ambitious Eagle will creep along the Bute coast, 
also Arran-bound. I see the latter vessel calling at Kilchattan Bay, and note how the fishermen at the pier are clearing their nets of the silvery herring they have taken in the night, and how the forepart of their boat has become a mass of fishes which will doubtless soon be packed in the boxes on the quay and dispatched to feed the city-dwellers far and near. Then I see Corrie nestling under Goat Fell and the hills around, the flag waving over its little hotel, and girls in bright lawn-tennis costumes staying their game till the steamer has passed.

Brodick also I see, with its castle perched on the hill-side; Lamlash, with its bay, and Holy Island sheltering it; and Whiting Bay too, with its big boats that ferry passengers to and from the steamer. Here, on this lazy day at Toward, one imagines these scenes clearly enough, and wishes it were possible to see them again, for the first time in all the beauty of a sunny day.

But there are "wells of content" at Toward, and there is wealth of thought enough-or oblivion of most things, if you prefer the latter-to be found here on this sweltering August day. The Clyde is like a lake, and the white-winged yachts are simply playing the rôle of "painted ships" this morning, and envying that beautiful steam-yacht-lilac-tinted, and neat and trim as a man-of-war-which has just rounded out of Rothesay Bay, and is making up the estuary at a speed of fifteen knots or so. Over yonder, the Cumbraes lie bathed in sunlight, and look like golden isles set in a sea of glass. It was a cleric dwelling on these islands who prayed that the Almighty might "bless especially the Greater and Lesser Cumbraes, and the adjacent islands of Great 
Britain and Ireland!" This is a local story, at least ; if true, I opine that clergyman, like the Kilbarchan weaver, must have prayed that he "micht have a gude conceit o' himsel'." And his prayer, doubtless, was abundantly answered.

You ask what is Lamlash famous for, and I reply, its bay; and its bay is in turn noted as being one of the settlements of a certain interesting member of the starfish group. Do you see that broken starfish which has been tossed up on the seaweed at our feet? Look at it attentively for a moment, and I will tell you the story of the Lamlash starfish. This fragment of starfish life which has been cast up at Toward is a "Brittle-Star."

It gets its name from the fact that it has a habit of parting as easily with its rays or arms as some people have of parting with their promises. Its body, you observe, is composed of a central part or disc, and the arms are mere appendages to this disc. This is very different from the case of the common starfish we dissected some weeks ago. There, the arms were part and parcel of the body, and the stomach and other organs ran into the rays, on the under-side of which you saw the hundreds of tube-feet. Here, in our brittle-star, the body is really represented by the central part, and the arms do not contain any prolongations of the organs or belongings of the body. Now, this brittle-star, like the sand-stars, finds itself placed in a class of its own, on account of these and other peculiarities of structure; and such a proceeding is as justifiable in its way as that which puts a snail in one division of the Gasteropod class, and a limpet in another.

Yet another kind of starfish, however, was known 
long ago to naturalists, and it is this third variety for which Lamlash Bay became famous. I observe that the bay is getting the credit of scarcity as regards its starfishes, but I sincerely hope this is not the case. Be that as it may, it is the "Rosy Feather Star" for which Lamlash became famous in its day and generation, and it will alway's be with this starfish in particular that the zoological mind will associate the pretty bay of Arran, with Holy Island as its outer bulwark and protection. The rosy feather star is not unlike that hrittle-star that lies at our feet, in respect of its

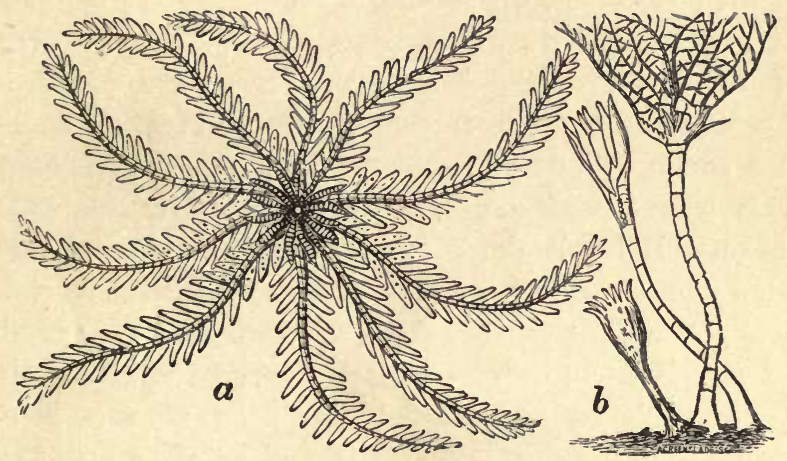

Fig. Ir.-Rosy Feather Star (a) and Stalked Young (b).

general appearance; but its colour is pink, as its name indicates, and its arms exhibit processes or appendages, as the term "feather" would imply. The organs are confined to the central body-disc, so that it is not by any means a near relation of the common five-fingered starfish which the waves so frequently cast up on the beach.

In the rocks we find the fossil-remains of curious starfishes set on stalks, and known as crinoids. Preserved as fossils, they are often popularly known 
as stone lilies or encrinites. It is the joints of their fossilised stalks, found by the thousand in some limestones, that Sir Walter Scott speaks of in "Marmion" as "Saint Cuthbert's beads." The crinoids are represented to-day by only a few living forms. Deepsea exploration added to their number, certainly, and dragged from the abysses several stalked starfishes which had been regarded as being wholly extinct. These typical crinoids (fig. I0), whether alive in the deep ocean to-day, or fossilised as remnants of farback populations of forgotten seas, spent the whole of their existence on stalks.

Yet, somewhere about I 840 or so-I am not sure of the exact date-Mr. J. V. Thompson found in the Cove of Cork a curious starfish set on a stalk, and which was duly named the Pentacrinus Europoens. This was a veritable treasure-find-in a zoological sense. If I mistake not, no living crinoid had then been found in European seas, although, afterwards, Sars brought to light another form dredged off the Lofoden Isles. Next in order came the curious fact that $\mathrm{Mr}$. Thompson's stalked starfish left its stalk at a given period in its life-history, and, lo and behold ! appeared before the eyes of naturalists as our old friend the rosy feather star, of Lamlash, and elsewhere.

So that the famous star of Lamlash is not an ordinary starfish at all. It is a crinoid, in fact-a member of the stalked starfish race, and a creature of aristocratic lineage, if we are to judge high life by "a lang pedigree." Compared with our rosy feather star, the starfishes of the beach are probably very modern beings, relatively speaking, although they too go far enough back in the geological record as fossils. The star of Lamlash differs from the deep-sea crinoids 
in that it spends part of its life (fig. I I $b$ ) only in the stalked state. Other crinoids spend the whole of their lives in this fixed condition. Here we find a link, perhaps, in the chain of causes which have wrought out starfish destinies.

Perhaps our modern brittle and other starfishes are derivatives of stalked forms; and the rosy feather star, in leaving its stalk, shows us how the free and unstalked life was evolved. This may be a statement I cannot prove, therefore I only suggest it as a likely theory, in view of the fact that one likes to be able to imagine why one starfish is stalked and another not. But the sun makes it too hot for philosophy to-day, and so we shall stroll back to Innellan to lunch, past the church which nestles in the trees at Toward, and onwards past the bright villas that make this corner of Clyde resemble a Naples nestling on the sea. 


\section{VIII.}

\section{ZA Cuttle=JBone.}

To-DAY, a friend who is by no means curiously inclined regarding science at large brought me an object which he alleged he had purloined from the cage of a canary bird in the house of an acquaintance. Curiosity had for once got the upper hand of him, and, after a hot discussion with the owner of the cage and bird regarding the nature of the object in question, my friend seized the article in question and bore it off in triumph for elucidation on my part.

The object was a plate of lime- to be strictly correct, of carbonate of lime, or, in plain language, chalk. It was of oval shape (fig I2), about four or five inches long, convex on one side and flattened on the other. More closely inspected, it was seen to be made up of layers of limy matter, superimposed one on the other. This object is familiar enough, as I assured my friend, in every bird-dealer's emporium. It is hung in the cages of birds that they may peck at it, and obtain therefrom the limy materials which are essential for their health, especially in reference to the laying of eggs and the due formation of the shell. The birdowner had assured my friend that the object was a "cuttlefish-bone;" and so, doubting the science of his acquaintance, he bore off the disputed article to me, 
thinking that a zoological opinion on the matter might be worth having.

Under the common name of the "cuttlefish-bone," it is perfectly true, the limy plate is sold. It still makes its appearance in pharmacy (being used for tooth powder) under that name: although it is not in any sense a bone, and, although a cuttlefish, one may add, is not a skeleton-possessing animal.
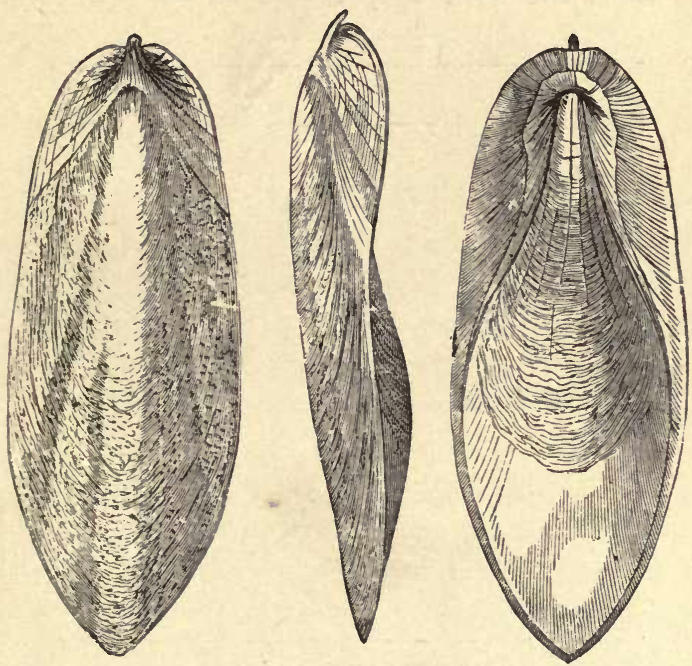

Fig. 12.-Cuttlefish Shells.

To begin with (as I informed my friend), he must first of all turn his attention to cuttlefishes at large. In the Brighton Aquarium or elsewhere he had seen the Octopus(fig. I 3); and on the sea-beach at Dawlish he had picked up the dead bodies of numerous Sepias, which are near cousins to the "devil fish" itself. Octopus and sepia are both very typical cuttlefishes, and the list might, of course, be greatly enlarged. There are 
the squids, or Loligos, with their arrow-shaped tailfins and their elongated bodies; and there is the Argonaut, or paper nautilus, and the pearly nautilus, with its distinct shell, familiar when polished to everybody as a drawing-room flower-vase.

This, then, was my first proceeding in the case of the "cuttlefish-bone" - so called-to instruct my friend in the nature and forms of the cuttlefishes. This done, the next step consisted in my reminding

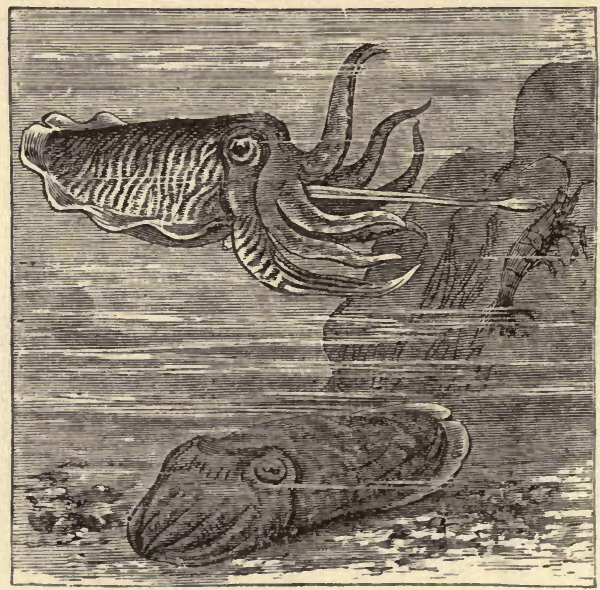

Fig. 13.-Octopi or "Devil-fishes."

him that these animals are Molluscs - that is to say, they are relatives of the snails, oysters, mussels, ct hoc genus omne.

In a word, cuttlefishes are "shell-fish," properly so designated. They stand at the head of the molluscan group, just as quadrupeds (including homo sapiens) stand at the top of the backboned type of animal life. This remark settles the position of the octopus and its 
neighbours in the animal scale, and shows that they are true shell-fish by right of birth and by all the lawful titles which a distinct zoological position can confer. Bones, it is true, they have none, for these structures are the exclusive possession of the backboned group; hence, if the limy plate found in the canary's cage proved (as prove it did) to be a cuttlefish belonging, it is clear that to call it a "bone" was a contradiction in terms.

The limy plate, in truth, is not a bone, but a "shell." Unlike a shell in every respect, it nevertheless duly represents, in the sepia-cuttlefish, the familiar structure we see in the snail or the oyster. We know this, first of all, because it is made by that part of the animal which in other molluscs, and also in other cuttlefishes, manufactures the shell. This is the outer layer, or integument of the body, which, in natural history language, we call the "mantle."

Whatever structures this layer forms and secretes are "shells," in the true sense of the term. The objects it manufactures, like the shell of the sepiacuttlefish itself, may be utterly unlike shells. As such, they may not be recognised at all; yet in their nature they are shells nevertheless. If we turn for a moment to two other cuttlefishes, we may be able to prove this assertion very easily.

There is a cuttlefish, extremely rare indeed as a living animal, but whose shells, as I have remarked, are common enough in drawing-rooms. This is the pearly nautilus (fig. I4). It is like the "last of the Mohicans," in that it is the sole survivor of a once large group of shell-possessing four-gilled forms. Its shell is of very perfect character. It is divided into compartments, each of which the animal successively 
inhabits. As it grows too big for its receptacle, it partitions off the old apartment, and adds a new chamber to its house, living in the last-formed and biggest of the rooms. Now, this perfect shell of the pearly nautilus is made by the "mantle," just as the shell of the snail or oyster is fabricated by that layer of the molluscan body.

Turn we now to the argonaut, or paper nautilus. Here, also, we find a shell ; but it is not a true shell, because it is not formed by the "mantle" of the

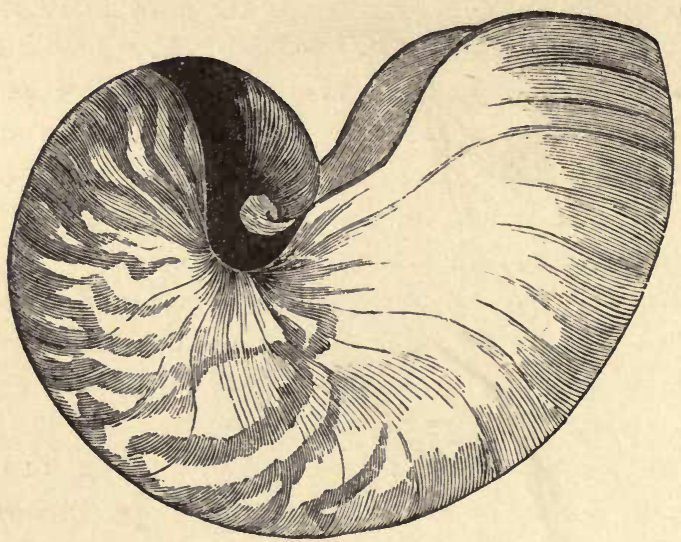

Fig. 14.-Pearly Nautilus Shell.

animal. The delicate papery shell of the argonaut is made by two of the arms of the animal, and therefore does not agree with the true shell of the other nautilus. Cuttlefishes, however, have undergone a very large amount of modification as living forms. To-day it is the sepias and the octopi and their kith and kin which swarm in the seas. They are active, free-swimming animals, which do not depend on a shell for protec- 
tion, as does the pearly nautilus of to-day, or as did the old extinct and fossil allies of the last-named animal. They are wary and agile in all their movements, and have apparently got rid of their shells entirely; just as the slug of the garden has relinquished his shell (seen in his young state), while his neighbour the snail has retained that possession of molluscan life.

Yet closer examination reveals that the sepia and octopus and other modern cuttlefishes have not wholly surrendered their shell-making instinct; for, lying on their backs, imbedded in their "mantles," we find shells of rudimentary description. This shell in the sepia is the "cuttle-bone" of the bird-shop and drug-store.

It is a lingering remnant of shells which, once upon a time, were very well developed in the ancestors of the sepia and its friends. It has dwindled away till it has become a mere plate of lime, bearing faint and feeble traces

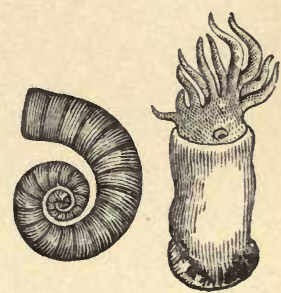

Fig. 15.-Spirula and its shell. of a once complex structure. In the squids or loligos, which are used so largely for bait by the Newfoundland fishermen, the shell has become degraded until it forms a mere horny " pen." So that what my friend purloined from the canary's cage is really a curious example of a shell that has gone to the wall in the struggle for existence, simply because it was not needed in the life and wants of the modern cuttlefishes.

This much is certain from ordinary natural history science alone. If, however, we were inclined to doubt the correctness of the inferences we have drawn, we should be able to find additional proofs in the shape 
of other cuttlefishes. The extinct belemnites are cuttlefishes in which the shell had become internal, while still retaining many of the characters of an outside shell.

In the little living spirula (fig. I5) the shell, we observe, is becoming internal. So that we have all the stages at command-showing us how an outside shell in these animals has become internal; how it has become further degraded; how it has attained to a yet more elementary structure; and, finally, how, being no longer needed by the animal, it makes its appearance in the guise of a mere plate of lime, gathered from the sea-beach to feed our birds with their mineral food under the name of the "cuttlebone." 


\section{IX.}

\section{$\mathfrak{z}$ Curfons Colony.}

THE fine weather tempted me the other day to visit an old haunt of mine situated on the shores of the Firth of Forth. This haunt, or "howf," to use the Scotch equivalent, is famous alike for zoological excursions (by sea), for its fishing industries, and last, though by no means least, for its fish dinners. A kind of Scottish Greenwich this, but with a prospect fair to see, and far exceeding the Thames in respect of its scenery and surroundings. Before you lie the blue hills of Fife; away to the east Inchkeith stands out on the bosom of the Firth; and North Berwick Law can be easily seen on a fine day, reminding you of an ancient Vesuvius which, once upon a time, may have belched forth fire and fury on the now quiet and respectable county of Haddington itself. Along the quaint High Street of Newhaven you meet with the fisher-folk. The women with their caps suggest the North of France at once to your mind; and the blue eyes and fair hair you meet with now and again tell their own story of Norse blood and of Viking invasion and settlement on the Eastern Scottish coasts.

To-day, Newhaven is dull and deserted. An air of melancholy seems to have marked the place for its own. A few ancient mariners loll on the pier-head 
and discuss the enormities and iniquities of steam trawlers in the monosyllabic and disjointed style of talk which characterises folk who spend most of their lives at sea. For your fisherman is a thoughtful soul, who dislikes being hurried over his talk, and who requires time to think out his ideas, and to express them in words. There is nothing doing to-day in the village, and I betake myself to the end of the pier, and enjoy the ozone and the fair prospect before me.

You are always certain to find food for reflection

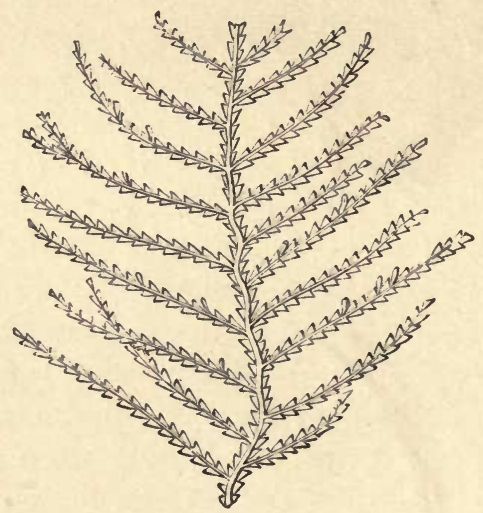

Fig. 16. -A "Sea-fir."

at Newhaven, however, if you are that way inclined. The pier to-day is littered with what I suppose the non-scientific mind would call seaweed. They lie in thick masses at one's feet as they have been stripped off the lines of the fishermen. Let us pick up a piece of this "seaweed" (fig. 16) and note its structure.

You observe it resembles a fir-tree in miniature. Its total length is about four inches, and you note that it grows rooted and fixed like any plant on 
oyster-shells and other objects. Little wonder that it is called a sea-plant, for its habits and its appearance certainly lend support to that view of its nature. Scan its structure, however, a little more closely by aid of this lens, and you observe that in place of leaves or flowers the branches bear hundreds of little cups set in each side. If you care to see what these cups are like when still more highly magnified, look at fig. I $7 a$. You perceive they are of definite shape, and do not agree with anything you recognise as belonging to the world of plants. In truth, this "sea-

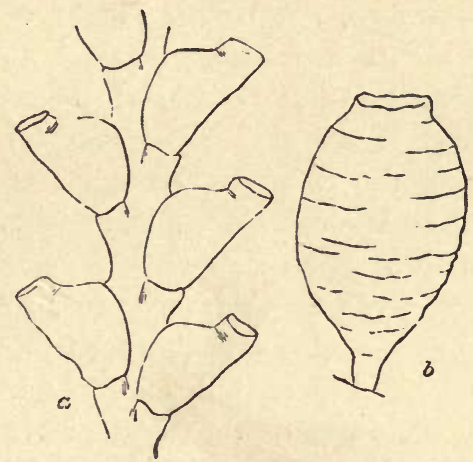

Fig. 17.-Sea-fir, largely magnified, showing its cups $(a)$; at $b$, one or its egg-producing capsules is shown.

fir" on which we have stumbled is not a plant at all. To cut short speculation, I may declare that it is a true and veritable animal, masquerading in the likeness of a plant.

To understand the constitution of the sea-fir you require to see one alive under the microscope. Then your gaze alights on a curious sight. You find that each of these cups or cells is tenanted by a living animal. Each unit of this colony is simple enough in structure. It consists of a tubular body, bearing 
a mouth surrounded by tentacles or feelers, used for purposes of food-getting. The mouth leads directly into the simple body; and the body, in its turn, opens below into the branch on which it is borne. Stem and branches are, in fact, hollow, and thus form a means of communication between all the units of the colony.

Our sea-fir is a compound or colonial animal, which numbers its members by the hundred. It is something more, however. It appears before us as a typical example of a co-operative society. For the colony is nourished, not by the labour of one, but by the work of all its members. Each little animal unit captures food and digests it, and then delivers this nutriment over to the general store or common fund, which is circulating always through the hollow stem and branches of the colony. From this common store each unit in turn draws its own supply.

There is perfect co-operation witnessed here. No wrangling and quarrelling, such as intervene in higher societies, exist. Lower life knows nothing of the overweening ambition of the twos or threes over the aims of the mass. There is no question or claim of precedence in the sea-fir democracy. All is harmony, equality; fraternity here; and the currents of sea-fir life roll onwards undisturbed by the passions of higher existence.

You are curious to know how this colony has come to be what it is. The story is a simple one. Look at fig. I 7 , and note the capsule marked $b$, which represents a growth that can be seen to appear in numbers on the branches. These are not ordinary cups or cells. They do not shelter ordinary units of the society. They are the cradles of the colony, and 
within them are developed the little masses of living matter which represent the eggs of the sea-fir. Sooner or later, these eggs are discharged into the sea. Each undergoes the special development of its race. It swims about freely for a time, like some errant animalcule.

Then it settles down, fixes itself to its oyster-shell, and we see growing out of the settled-down egg the likeness of one little member of the sea-fir state. By-and-by there begins a process of budding-as truly budding, indeed, as is seen in any plant. The result of this process is to produce other units like itself. The budding continues, and in due season we behold reproduced the connected branched colony with which we started.

That is the history of every sea-fir you may find. It arose from an egg which was developed in the eggcapsule of a pre-existing colony; and it grew to its vegetable form by its imitation of the ways of increase we see in every plant. This history might be indefinitely prolonged.

I might tell you of near neighbours of the sea-fir whose reproductive buds are represented by veritable free-swimming jelly-fishes, which mature the eggs from which in turn the colonies in due time spring. The main features of sea-fir life are unaffected by the complexities of its neighbours ; and to-day, on Newhaven Pier, you have at least learned one lesson in science-that animal life may closely imitate plantexistence in form and function, and that it is not always the higher life which most perfectly illustrates co-operation and that unity in which we are so strongly advised perpetually to dwell. 


\section{$\mathrm{X}$. \\ Zl JBit of জponge.}

THis morning, despite the promise of rain over-night, has broken with all the signs and symptoms of a bright July day. The Firth is bathed in sunlight, and the wavelets at full tide, are kissing the strand, making a soft musical ripple as they retire, and as the pebbles run down the sandy slope on the retreat of the waves. Beyond the farthest contact of the tide is a line of seaweed dried and desiccated, mixed up with which, in confusing array, are masses of shells, and such olla podrida of the sea.

Tossed up at our very feet is a dried fragment of sponge, which, doubtless, the unkind waves tore from its rocky bed. It is not a large portion of sponge this, but its structure is nevertheless to be fairly made out, and some reminiscences of its history gleaned, for the sake of occupying the by no means "bad halfhour" before breakfast. "What is a sponge?" is a question which you may well ask as a necessary preliminary to the understanding of its personality.

The questionings of childhood and the questionings of science run in precisely similar grooves. "What is it?" and "How does it live?" and "Where does it come from ?" are equally the inquiries of childhood, and of the deepest philosophy which seeks to determine 
the whole history of life. This morning, we cannot do better than follow in the footsteps of the child, and to the question, "What is a sponge?" I fancy science will be able to return a direct answer.

First of all, we may note that a sponge, as we know it in common life, is the horny skeleton or framework which was made by, and which supported, the living parts. These living parts consist of minute masses of that living jelly to which the name of protoplasm has
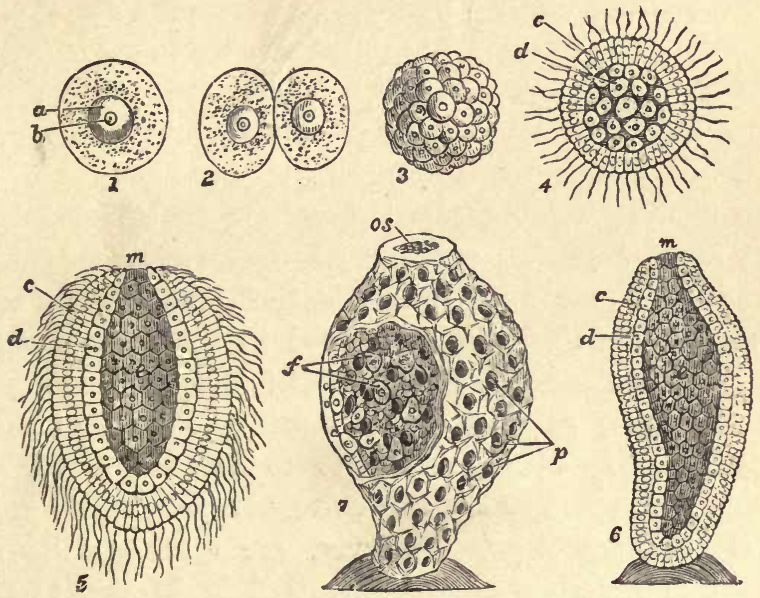

Fig. 18.-Development of a Sponge (Olynthus).

x, The egg; 2,3 , and 4 , the process of egg-division ; 5 and 6 , the gastrulastage; 7 , the perfect sponge.

been applied. This, in truth, is the universal matter of life. It is the onc substance with which life everywhere is associated, and as we see it simply in the sponge, so also we behold it (only in more complex guise) in the man. Now, the living parts of this dried cast-away sponge were found both in its interior and on its surface. They lined the canals that everywhere 
permeate the sponge-substance, and microscopic examination has told us a great deal about their nature.

For, whether found in the canals of the sponge themselves, or embedded in the sponge-substance, the living sponge-particles are represented each by a semiindependent mass of protoplasm. So that the first view I would have you take of the sponge as a living mass, is, that it is a colony and not a single unit. It is composed, in other words, of aggregated masses of living particles, which bud out one from the other, and manufacture the supporting skeleton we know as "the sponge of commerce" itself. Under the microscope, these living sponge-units appear in various guises and shapes. Some of them are formless, and, as to shape, ever-altering masses, resembling that familiar animalcule of our pools we know as the Amoba. These members of the sponge-colony form the bulk of the population. They are embedded in the sponge substance; they wander about through the meshes of the sponge; they seize food and flourish and grow; and they probably also give origin to the "eggs" from which new sponges are in due course produced.

More characteristic, however, are certain units of this living sponge-colony which live in the lining membrane of the canals. In point of fact, a sponge is a kind of Venice, a certain proportion of whose inhabitants, like those of the famous Queen of the Adriatic herself, live on the banks of the waterways. Just as in Venice we find the provisions for the denizens of the city brought to the inhabitants by the canals, so from the water, which, as we shall see, is perpetually circulating through a sponge, the members of the sponge-colony receive their food.

Look, again, at the sponge-fragment which lies before 
us. You perceive half-a-dozen large holes or so, each opening on a little eminence, as it were. These apertures, bear in mind, we call oscula. They are the exits of the sponge-dominion. But a close inspection of a sponge shows that it is riddled with finer and smaller apertures. These latter are the pores, and they form the entrances to the sponge-domain.

On the banks of the canal you may see growing plentifully in summer time a green sponge, which is the common fresh-water species. Now, if you drop a living specimen of this species into a bowl of water, and put some powdered indigo into the water, you may note how the currents are perpetually being swept in by the pores and out by the oscula. In every living sponge this perpetual and unceasing circulation of water proceeds. This is the sole evidence the unassisted sight receives of the vitality of the sponge-colony, and the importance of this circulation in aiding life in these depths, to be fairly carried out cannot readily be over-estimated.

Let us now see how this circulation is maintained. Microscopically regarded, we see here and there, in the sides of the sponge-passages, little chambers or recesses which remind one of the passing-places in a narrow canal. Lining these chambers, we see living spongeunits of a type different from the shapeless specks we noted to occur in the meshes of the sponge substance itself. The units of the recesses each consist of a living particle, whose free extremity is raised into a kind of collar, from which projects a lash-like filament known as a flagellum.

This lash is in constant movement. It waves to and fro in the water, and the collection of lashes we see in any one chamber acts as a veritable brush, 
which by its movement not only sweeps water in by the pores, but sends it onwards through the sponge, and in due time sends it out by the bigger holes, or oscula. This constant circulation in the sponge discharges more than one important function. For, as already noted, it serves the purpose of nutrition, in that the particles on which sponge-life is supported are swept into the colony.

Again, the fresh currents of water carry with them the oxygen gas which is a necessity of sponge existence, as of human life; while, thirdly, waste matters, inevitable alike in sponge and in man as the result of living, are swept out of the colony, and discharged into the sea beyond. Our bit of sponge has thus grown from a mere dry fragment into a living reality. It is a community in which already, low as it is, the work of life has come to be discharged by distinct and fairly specialised beings.

The era of new sponge-life is inaugurated by means of egg-development, although there exists another fashion (that of gemmules or buds) whereby out of the parental substance young sponges are produced. A sponge-egg develops, as do all eggs, in a definite cycle. It undergoes division (fig. I8); its one cell becomes many; and its many cells arrange themselves first of all into a cup-like form $(5,6$ and 7$)$, which may remain in this shape if the sponge is a simple one, or become developed into the more complex shape of the sponges we know.

In every museum you may see specimens of a beautiful vase-like structure seemingly made of spunglass. This is a flinty sponge, the "Venus flowerbasket," whose presence in the sponge family redeems it from the charge that it contains no things of beauty 
whatever. So, too, the rocks are full of fossil-sponges, many of quaint form. Our piece of sponge, as we may understand, has yet other bits of history attached to it which another day's talk may reveal. The breakfast bell warns us that science in another form (that of human nutrition) awaits our practical study. Meanwhile, think over the sponge and its ways, and learn from it that out of the dry things of life, science weaves many a fairy tale. 


\section{XI.}

\section{"The Thing of jisbes,"}

THIs morning, a walk through the woods will give us an appetite for breakfast, and start us fairly, perchance, on the spending of at least one holiday. I can promise you a fair prospect in so far as the walk itself is concerned, with something interesting at the end of our stroll. The woods this morning are redolent of balsamic odours, for which we have to thank the tall pines and firs that, like sable mourners draped in plumes, flank the pathway for half a mile or more.

Every leaf glistens with the jewels of the dew, and these "top lights," as an artist friend calls them, which the sunlight throws down from above, and from among the thick mass of overhanging foliage, make the vista before us seem almost interminable-such is the marvellous effect of light and shade cunningly interspersed. The bracken forms the undergrowth of the woods, and gives covert and concealment to the hosts of rabbits that swarm in the plantations around. Beyond the edge of the wood, parallel to the pathway we are treading, lies the frith.

You note this arm of the sea, appearing in all sorts of odd corners and ways, as you ramble through the fine old woods. Now and then, through some sudden crevice or break in the screen formed by leaf and stem, 
you may perceive the fair coast on the other side of the sea, lying bathed in sunlight. An open stretch beyond shows us a beautiful sandy patch of beach, and round the cliff there is another mile or two of sand. Nestling almost under the cliff is a solid, well-built cottage. Rows of stakes run out into the sea from the beach, and these bear a net which twice or thrice expands into pockets as the stakes depart from the straight line and assume a semicircular form.

Piles of stakes are stacked at the door of the cottage, nets hang about in profusion, and a coble or flatbottomed punt (with a prow) is drawn up on the beach close to the shelly margin which marks the highest lap of the tide. Long-shaped baskets made with strong osiers are packed and ready to be carted off to the nearest town. The baskets are stuffed apparently with the bracken fern that grows so profusely around; but a tail, sticking out beyond the fern-packing here and there, reveals the fact that the king of fishes is being sent off to the town, and that we are beholding the scene of his capture and of his ensnaring by the arts of man from his native depths.

The salmon fishery before us is an old institution. Capture here, smacks of the conventional. There is no play with rod and line, no hour or two of humouring your fish, of tiring him out, and of finally landing him triumphantly on the sward by aid of the lethal "cleek." Not in vain, however, do our sunburnt friends, the fishers, spread their nets out into the sea. Stake-nets and drift-nets capture the silvery fishes readily enough; and it would be difficult to say how many pounds' weight of salmon may be carried off to the city in a single day, after a big haul.

Be that as it may, one thing is certain - that the 
salmon is, of all our British fishes, the most notable, whether we regard it in its zoological or in its purely social phases. True, the herring runs the salmon very close indeed as a competitor for public favour. I have heard people, years after the event, recall to remembrance the flavour of the Loch Fyne herrings they had had served up to breakfast on board the floating palaces owned by Mr. MacBrayne of Clyde and Oban fame. Doubtless one may tıre very readily of salmon, for it is an oily fish withal; but it is certainly agreeable enough while the taste for it lasts, although your herring is always welcome, and, properly cookedthat is, split open and not fried whole-cannot possibly be excelled by any fish that swims.

However, these are desultory thoughts, and we will own the salmon the sovereign of the finny races, if you will. Like most royal personages, the salmon has a history; and it is astonishing that so little is popularly known of the fish and its biography. True, that history was for long a most debatable matter. The genealogy of the fish was by no means perfectly understood until within relatively recent years, owing chiefly to certain peculiarities which mark the manner of its becoming, and which characterise the fashion in which it spends the days of its youth.

From a tiny egg the salmon springs, like every other living animal of any respectability as regards rank in the living series. Laid in a kind of trench or furrow made in the gravel of the upper reaches of the rivers by the mother-fishes, the eggs are duly fertilised by the males, and then, covered up by the parents with gravel, the eggs undergo their preliminary stages of development. The spawning goes on in the late autumn and winter months, and may therefore be said 
to begin about the month of September, and to end about January.

Each river shows its own peculiarities, however, as regards the spawning season; but after a period, varying in duration from seventy to ninety, or even a hundred and twenty days or more, the young salmon fry hatch out, and appear as active little fishes, each with the yolk-sac of the egg still in process of absorption. A few weeks, however, see a marked change occur to the young salmon. It is then about an inch in length, its sides become marked by dark bands of very distinctive kind, and it is known to naturalists and fishers as the parr.

Long ago, there raged a hot controversy over the question, "Are parr the young of salmon?" Thanks to that actual observation which solves so many problems, and which would save so much discussion if it were only more frequently practised, this question can be affirmatively answered. Parr are salmon in the days of their infancy. Now, however, comes a striking fact in salmon history. The next change which the youthful fish undergoes is that of leaving off its parr-dress and appearing in the guise of the smolt. We now know that some of the parr don their smolt guise between thirteen and fifteen months after they are hatched; while others, and by far the greater proportion of the parr, do not become smolts until twenty-six months after they leave the egg.

Once having donned the smolt-dress, the salmon, now in the days of its youth, seeks the sea. Up to this period it has been a treshwater dweller. Between March and June the smolts hurry to the ocean. There we lose sight of them for a few months; but, when they reappear, we find that, as we say of our friends 
and neighbours after a holiday-season, their trip to the sea has worked wonders. They went to the sea, smolts, trifling in size : they return as grilse, weighing, it may be, four or five pounds, having, through the luxurious feeding they have enjoyed in the ocean, become young salmon, able to produce eggs.

For this purpose, indeed, the grilse has returned to its river, and many fishers hold that it never returns to any river save that which gave it birth. This, indeed, was Frank Buckland's own opinion: but one may venture to think that the returning grilse or salmon, while, as a rule, entering its native river, does not invariably choose its original waters. After spawning, the grilse goes back to the sea in the winter or spring, and, on its next visit to the river, appears before us as the salmon. Year by year it will increase in size, until it may attain the dimensions of the "forty-pounder" you heard the fishermen speak of the other day. Salmon have been caught weighing seventy pounds; but this was, no doubt, a giant of its tribe, such as we seldom see. 


\section{XII.}

\section{Itartisbes.}

"As there are stars in the sky, so there are stars in the sea," remarks an old writer, whose knowledge of things in general, if not very specific, was, at least, of a fairly wide nature. The remark occurred to my mind this morning when, during a stroll along the sea-beach, I came upon a familiar "five-ray" lying in a truly helpless condition on the sand. There is nothing more helpless-looking in nature, I should say, than a starfish cast up on the sandy beach by the unkind waves. Placed among rocks or near seaweed-clad pools, our sea-star is quite at home. Even if, like a helpless and floored turtle, he has been turned over on his back, he will contrive to right himself, and escape to his watery abode, or move with his slow and stately walk over the rocks. But he seems to feel that the sand is a disagreeable and shifty form of surrounding, and he makes little or no effort to bestir himself, but lies flaccid and limp until, perchance, the returning tide sweeps him off into the welcome depths.

My sea-star of this morning is lying face uppermost in the sun, and, if he could pant as does the higher animal, I have no doubt he would indicate his resentment in that familiar fashion. As it is, you can see the tube-feet, which exist in dozens in the grooves 
that run along his rays or arms, moving backwards and forwards, here and there, as if in protest at the treatment to which their owner is being subjected. Truly, an unkind fate has taken the star from its watery firmament and stranded it at our feet, which shows, in truth, that accidents and emergencies befall humble beings as well as creatures of high estate. There is some consolation, I think, even for mankind,

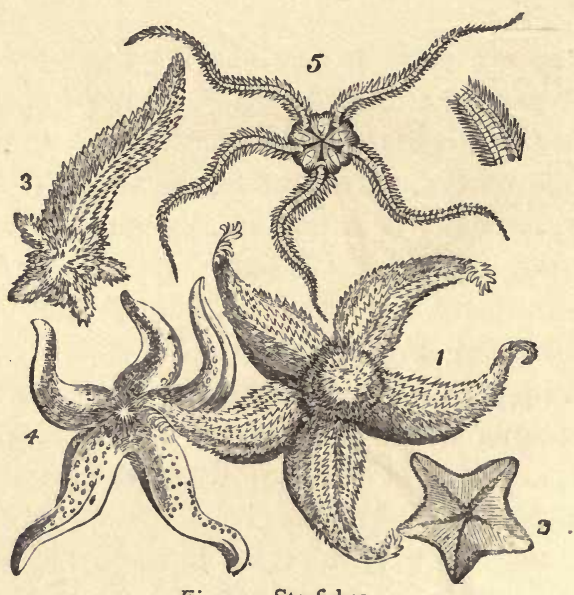

Fig. 19.-Starfishes.

x, The Common Starfish ; 2, A Cushion Star ; 3, A Starfish with one perfect ray and four new rays budding out ; 4, A Smooth Starfish; 5, A Brittle Star.

in the spectacle of untoward events troubling what mind even a starfish may be regarded as legitimately possessing.

Protriding from the starfish mouth, which exists in the very centre of its under-surface, we see a clear jelly-like mass. This is part and parcel of the stomach, which extends into the rays of the animal. It may be that our star is taking this rather inelegant 
mude of showing its disgust at the contretemps which has beset it this morning; but, all the same, this protrusion of the stomach may be the result of a habit of the animal. If you were to ask any of the fishermen - who, as becomes the ways of nautical persons, are promenading up and down in a kind of set groove on the pier, and exchanging monosyllabic ideas with their neighbours between their frequent glances seawardswhat the starfish does with its stomach, you would be provided with a speedy reply. They would tell you that the sea-stars are enemies of the oyster-beds, and may add that they kill more oysters than mankind consumes.

Hence, whenever a starfish is found in the dredge, it is ruthlessly torn in pieces and flung overboard as a just recompense for its predatory habits. How far the fishermen's views of starfish guilt are justified I scarcely know; but I should say their opinions are not without warrant. You may often pick up a starfish on the beach which has its arms coiled up until it has come to resemble a living ball, like its neighbour the sea-urchin.

Disentangling the starfish and its arms, you find it has been embracing a whelk, and, as you liberate the shell-fish from the grasp of the star, you draw forth from the shell the stomach of the starfish. It has been slowly sucking out of the shell the substance of its living tenant, and that it preys upon its molluscan neighbours is, therefore, matter of certainty. Whether it can attack the oyster is, however, quite a different matter. That mollusc is as secure within its shell as a baron of old in his fortified citadel. By closing its shell, it can certainly entrench itself in a fashion which no starfish can readily break through. 
Yet oysters have to open their shells in time in order to breathe by inhaling the water; so that it may be, our starfish, clasping its oyster, bides its time, and when the shell is opened attacks the mollusc. There are difficulties, however, in the way of accepting the fishermen's belief, for the eviction of an oyster from its shell by a starfish would, on the best showing, be a very long and laborious matter. One belief of naturalists is that the starfish poisons the oyster by inserting from its stomach, between the valves of the shell, some poisonous secretion, which compels the mollusc to capitulate and surrender. Anyhow, the belief is a curious one, and one may not be surprised if on this occasion the fishermen's ideas are regarded with greater favour than science usually accords to the folk-lore of the dwellers by the sea.

Drop the starfish into this pool and watch its movements. You have seen the hundreds of little tube-feet, each ending in a sucker, which the grooves on the under side of the rays contain. You observe that it soon begins to crawl over the patch of rock on which it has been dropped. Turn it over on its back in the water, and observe how the feet move and wriggle. Let us watch how the capsized animal rights itself. Slowly but deliberately you see it twists over the tip of two of its rays, until the tubefeet have become attached to the rock.

This is to give it a fulcrum or point d'appui, from which to lever itself back to a respectable position. The tips of these rays are firmly fixed to the rock, and in turn the under parts of the two rays are brought by the successive attachment of their feet in contact with the rock-surface. Acting as levers, the 
rays, which, as we have seen, are each moment increasing their surface of attachment to the rock, are finally fully fixed thereto. Finally the body and other rays are twisted or swept over, and the star finds itself at last in its natural position mouth downwards.

These tube-feet are unique as regards the starfish class. You may note on the upper surface of the star, at the angle formed by the juncture of two of the rays with the body, a round plate. This is the "madreporiform plate," and, like the lid of a pepperbox, it is perforated with holes. It acts as a strainer, and keeps solid matters from getting into the tube to which it serves as an entrance. This tube leads downwards to another and circular tube, inside the starfish body and surrounding its mouth. From this circular tube pass five other tubes, one for each ray.

Now, if we dissected our starfish, you would find that the tube-feet are given off from the main tube or each ray or arm, and each tube-foot has at its attached end, or base, a little bag or sac. The whole apparatus I have described is one whereby, through the admission of water to the system of tubes, the tube-feet can be distended or the reverse, and the movements of the animal be duly provided for. If the starfish wishes to walk, water is sent from the little sacs at the bases of the feet into the tubes. These latter are thus rendered tense. Their suckers are applied to the rock-surface, with the result that part of the water is forced back into the sacs, the sucker is left firmly adherent by the pressure of the sea-water outside. Then, by forcing the water from the sac into the tubefeet, the suckers are set free, and, by this alternate contraction and expansion of the tube-feet, the adhesion of these organs or their freedom is secured. 
Space does not permit that, at present, I should say anything about the nerves and other belongings of the sea-star. It is a "steady and stolidy" animal, no doubt, but it has its own share of "the mind universal" after all. Meanwhile, we shall leave it in its pool. A humane action in restoring the star to its native waters has perchance brought its reward in suggesting the thought that in even mean creatures there are ways and works well-nigh past finding out. 


\section{XIII.}

\section{ฐea =đarcbins.}

A COLD, bright winter's day this, in which the sea air blows keen and sharp from the Channel. Eastbourne this morning, however, is looking its best. The sun is shining as brightly as if it had mistaken January for April or May, and while King Fog reigns supreme in London, the Sussex coast is bathed in light. The tide has receded far beyond the lower parade in which Eastbourne rejoices, and although there are no crowds of promenaders as in summer, there is a goodly muster of Eastbourne natives and visitors on the sea-face of this trim little town.

Beachy Head looms out clear and sharp before us, and ships in full sail are beating up Channel against wind and tide alike. A fisherman is assorting his lines close by where I stand, and prophesies "a bit of a blow" as a future enjoyment. But the present aspect of affairs is decidedly spring-like, and the smooth sand before us looks inviting enough for a stroll in search of the treasures of the deep. Stoutly shod, you need not fear the sand. It looks wet, but that is a mere optical illusion, after all is said and done; and you may spend your forenoon to better purpose-both in the way of ozone and of mental enjoyment - in a stroll 
by the sea than in lounging in those cosy rests on the parade above.

Away Hastings and Pevensey way, the sand stretches smooth and inviting; towards Beachy Head, you come upon rocks and stones, which form a haunt of not a few species of anemones and other sequestered beings. So, setting our faces to the wind, we start on our pilgrimage, leaving footprints on the sands of Eastbourne as we trudge manfully down to where the waves, with something of spent fury from last night's storm, still break in surf upon the shore.

This stretch of bare sand looks anything but promising for natural history students; yet among the flotsam and jetsam of the waves there are prizes to be picked up, often in large numbers. We are in luck's road this morning, for here, at our feet, the sea has tossed on shore a curious organism, which, at first sight, looks like a spiny apple or orange. That is an Echinus or sea-urchin-the "sea hedgehog" of the ancients, as its scientific name implies. It is a globular mass, this we have found, bristling with spines, and, like an orange-or the world itself-somewhat flattened at the poles. Looking carefully between the spines you can see the shell, or limy case, in which the soft parts of the animal are contained; and when we arrive at home we shall drop it into that aquarium in which our Eastbourne friends delight, and notice how life progresses within the sea-urchin's domain.

Meanwhile, we may discuss the nature of the Echinus-body on which we have thus stumbled by a lucky chance. That starfish you see on the beach is a near neighbour of the sea-urchin, although the relationship may not be apparent on a superficial acquaintance with the two animals. The type of body is, 
nevertheless, the same; and if you could imagine your starfish doubled up into a ball-shaped form, so that the tips of its five rays would meet together at the top of the ball, you would produce a tolerably close likeness to the sea-urchin's organisation.

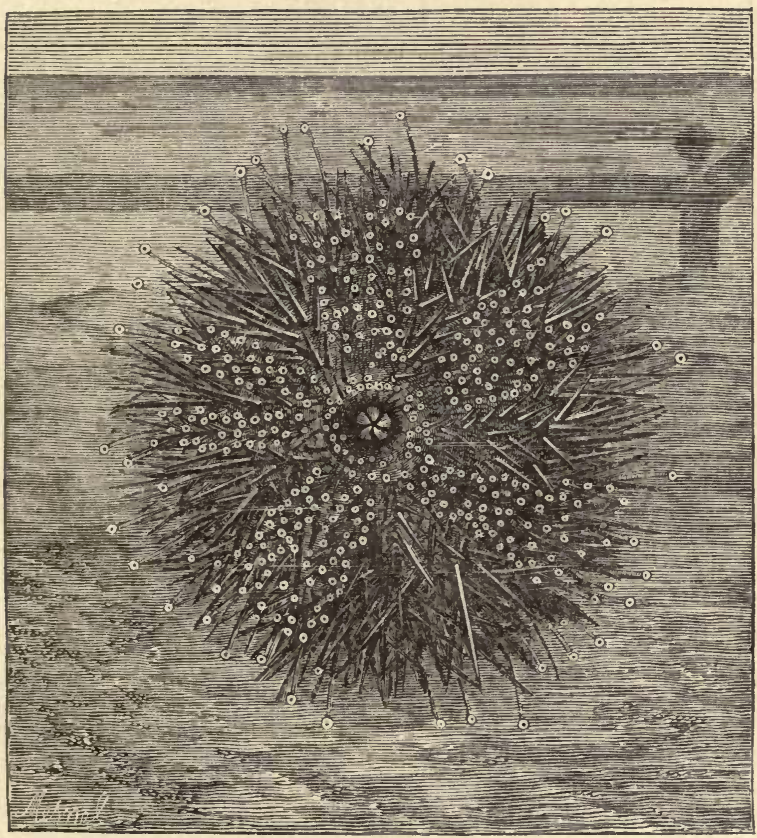

Fig. 20.-An Echinus viewed climbing on the glass of an aquarium.

The mouth and its five jaws are seen in the centre.

Included in the starfish class is yet another type of animals known as the sea-cucumbers. These are common enough round our coasts, and are often brought up in the naturalist's dredge. The seacucumbers are the "Trepangs" of the Eastern Archipelago, and dried "Trepang" is a dietetic luxury of 
John Chinaman when at home. Now, our sea-cucumber, in place of being either star-shaped or ball-like, has a body of somewhat elongated form. At the mouth end it has tentacles, and along its body there are five rows of tube-feet. So that, just as we may suppose a starfish to be a spread-out sea-urchin, we may compare our sea-cucumber to a sea-urchin drawn out lengthwise. All three types of the starfish family-circle, in fact, are modelled on one and the same broad plan.

So much for the near relations of the sea-urchin, or "sea-egg," as it is also named when, with all its spines torn off, you find its shell lying on the shore. We pop it into our glass tank, and in a short time, as sketched in the above illustration, you find it climbing up the side of its abode. That aperture you see in the middle of the body is its mouth, and if you look closely at this opening you may see projecting therefrom the tips of the five teeth or jaws, which form the so-called "Lantern of Aristotle." By aid of these jaws, set in movement by a complex set of muscles, our Echinus contrives to masticate the seaweeds and other tid-bits on which it subsists.

Notice next how the sea-urchin climbs on the glass. These round white spots (each with an aperture in the middle) which are disposed in five rows running up and down the shell from top to bottom, you perceive, on closer examination, to be tube-feet (similar to those of the starfish), each capable of active movement. These feet can be withdrawn into the shell. They are protruded through holes in the limy casing when movement is the aim of sea-urchin existence; and in order to become tense and stiff, and thus enabled to support the body, the feet are distended with water. When not required for movernent, the water is ejected 
from the feet, and they can then be withdrawn in their soft and flaccid condition into the shell.

It is curious to observe how the organs and parts of the sea-urchin, starfish, and sea-cucumber bodies are arranged in fives. Look at this dried shell of the Echinus. You see it is beautifully built up of sixsided plates of lime, firmly united to one another, and arranged in ten zones, running from top to bottom of the shell. Five of these zones are perforated with holes for the emission of the tube-feet; the plates of the intervening five zones being imperforate. Now, if you anatomise the sea-urchin's body, you will find therein the same law of number regulating its structure. There are five chief nerve-cords, and five eyes at the top of the shell; there are five tubes carrying water to the feet, and there are five main blood-vessels. The starfishes show the same number of parts, and so do the sea-cucumbers.

If we were dealing with plants, we should call this phase of matters their "symmetry," for you find that a law of number is also represented in flowers and their parts. The primrose has five sepals, five petals, five stamens, and five carpels : and your buttercup has the same number of parts in sepals and petals, while its stamens and carpels are present in multiples of five. The lilies, tulips, crocuses, and snowdrops, on the other hand, have their parts developed in threes or in multiples of three. So that we observe how the arithmetic of living Nature is not represented by mere chance in her modelling work; and in the starfish tribe it is very clear, instead of considering " number one," as the phrase runs, she may be said to have devoted all her energies to " number five."

The sea-urchin has a very ancient history as a 
family group. Away back in the mists of the ages, sea-urchins lived in primitive seas, and left their fossils to testify to the long descent of their race. Even to-day the family group possesses certain queer members which deep-sea dredging has brought to light. In one of these rare sea-urchins, the shell, instead of being rigid and brittle, has its plates flexible.

When first my late friends, Dr. W. B. Carpenter and Sir C. Wyville Thomson, saw this flexible urchin heaving and panting on the deck of the Porcupine, and finally collapsing as it were, the one remarked to the other, "This looks as if you had sat on it." But although these aberrant urchins are the rarities of science, we still possess in the homely Echinus of our own shallow seas a creature whose whole build and history is nothing short of a natural romance. 


\section{XIV.}

\section{૬ome IDtxed tRelationsbíps.}

In the old days of natural history, when there existed a veritable mania for defining "species" of animals and plants, and when a man's whole energy might be absorbed in the task of labelling living beings as if they were pots and pans in a warehouse, scarcely any doubt was ascertained regarding the exact and distinct nature of each kind of living thing. A crow, a chough, and a raven are probably three distinct species of birds. They are distinguished from one another by certain marks, not, it must be admitted, of very special character. They are, nevertheless, readily recognised as crows, choughs, and ravens respectively, whenever they are scrutinised by the practised eye.

Again, their young hatch out into crows, choughs, and ravens, and there does not appear to be any admixture of the blood or breeds of these birds. So we say they are true "species" - the crow resembles his "kind," and the chough his kind, and there, it might be thought, is an end of the matter. Unfortunately, however, instead of the matter being thus finished and done with, it is only begun. For, first of all, it is clear that to-day nobody who pretends to an intelligent interest in the world of life rests content with the assumption that these birds have from time immemorial 
always exhibited the slight differences on which our ideas of their distinct and separate nature are founded.

We are, all of us, anxious to pierce by the eye of scientific faith the obscurity in which the past of living beings lies hid. The thought is borne in upon us day by day that, so far from species of animals being "steady and stolidy" quantities, they are rather to be regarded as being of very variable nature indeed. For we know that living beings do vary and altersome to a great extent, others scarcely at all, but one and all showing a tendency or bias towards change. If this idea (which I need hardly add is the basis of all modern biological thought) be admitted as worthy of further pursuit, it is not difficult to find many examples of relationships among animals, and plants also, which, in schoolboy language, appear as of a decidedly " mixed" character.

What, for example, are we to make out of the following case, the facts of which are perfectly well ascertained? On oak-trees grow the galls which are used in ink-making and in medicine. A gall is an excrescence, which, as most of my readers know, is due to the work of an insect. The gall-flies (of which the best-known group is that called Cynips) thus derive their popular name from their habit of gall-production. The mother gall-fly possesses a hollow pointed tube which is known as the ovipositor. Down this tube pass the eggs which she fixes on the oak-tree. The gimlet-like ovipositor pierces the tree's bark, and some irritating fluid is doubtless injected into the planttissues along with the egg.

At any rate, the tree swells at the seat of the puncture, and soon the gall appears; the excrescence developing in this way as the investment of the young insect 
which, hatched in due season from the egg, passes its early stages within the vegetable tissues. Out of the gall, when its time arrives, the young gall-fly will issue forth. Now, it is needless to say that, in bygone days, zoologists very faithfully catalogued, defined, and described the gall-fly family in all its branches. This group of insects constitutes a well-known branch of the great class of winged things. One might conclude, with reason, that little was left to be desired in our knowledge of gall-fly habits or of gall-fly appearances. Yet, as the sequel will show, the relationships of these

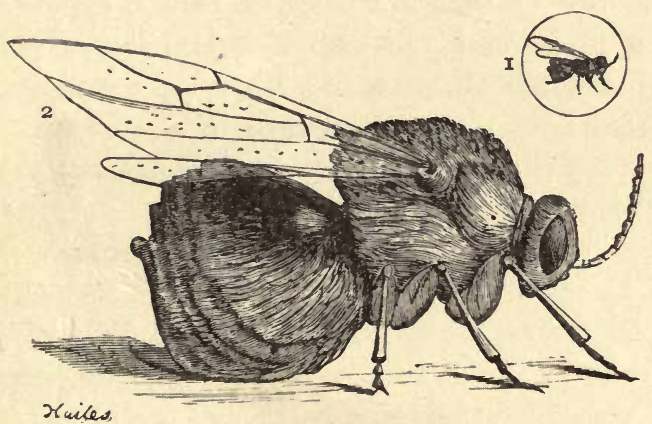

Fig. 21.-Gall insect (Cynips kollari), (x) natural size and (2) enlarged.

estimable insects are getting decidedly "mixed," and the increase of knowledge in this case is becoming, as it too often does, an increase of sorrow to the otherwise contented mind of the natural historian.

The newer story of the gall-flies begins with the observation that down in the roots of the oak-tree, and in those parts of the roots which are but sparsely covered with earth, there reside gall-insects of peculiar kind. They come forth from their ground-galls as wingless forms, and they are all mother-insects. It is curious also to observe that they cannot reproduce the 
galls from which they spring: so that, at first sight, an element of mystery clearly attaches to these wingless females.

From another part of the tree, in spring, issue forth the ordinary gall-flies. They arise from the galls borne on the ends of the branches, and these latter insects are winged, and exhibit a due proportion of both sexes. To the wingless mothers of the roots the name of Biorhizas has been given; while the winged males and females are placed in the group known by the term Teras. That the two kinds of insects are of different species would appear to be a very plain and reasonable inference. Habit and appearance are surely much more clearly defined and separated here than in the case of our crows. This much goes without saying. But all has not yet been told about the two kinds of gall-flies.

From the roots, then, come the Biorhizas. They climb up the tree in a slow and deliberate fashion, as becomes insects which have no means of flight. Then they pass to the branches of the tree, and climb out to the very ends thereof. Next they begin to lay eggs (which, by the way, are not fertilised, of course) in the branches, and each egg is developed inside a gall. Out of these Biorhiza-eggs, strange to relate, come the winged Teras insects, so that first of all we see apparently one species of animal giving origin to another and entirely distinct species. The story then proceeds to show that the Teras insects in their turn (winged males and females as they are) produce fertilised eggs, which the mother Teras deposits in the roots of the tree.

From these root-galls, as we have seen, the wingless Biorhizas are duly developed; so that we find in 
this case a kind of mutual and alternating exchange of parentage. The Biorhiza gives origin to the Teras, and the latter, in its turn, develops the Biorhiza. To use a very old simile, the offspring never resemble their parents, but their grandparents. It is a simple truism, then, to say that, somehow or other, the gallfly relationship have become of a character certainly "mixed" in their type.

One explanation, at least, of this curious interchange of personalities-not unknown, by the way, in other insects and in other groups of animals -is perhaps more easily found than might at first sight be supposed. The history of our gall-flies is one in which apparently a youthful form of a species has acquired a wonderful power of producing young. We have to wait for the adult stage of things, as a rule, before the animal illustrates the power of like begetting like. Now and then, however, we do find that the young form has acquired a power of producing eggs, and

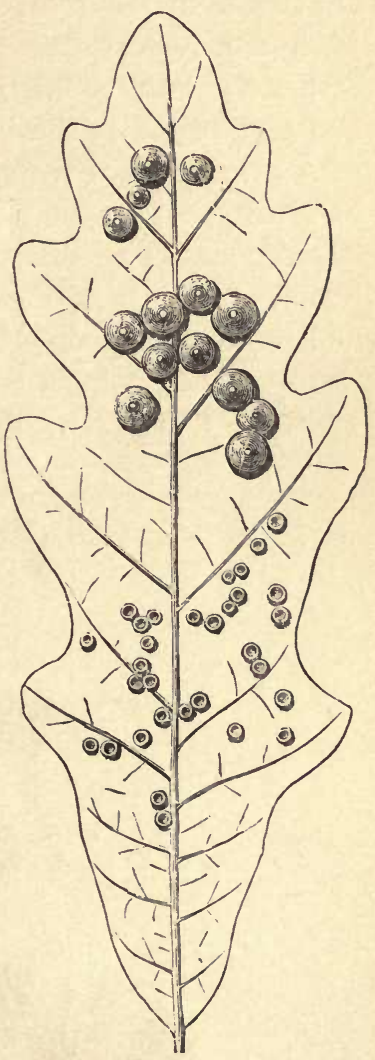

Fig. 22.-Galls on oak-leaf : "spangles" and "button galls." of giving origin to new beings, as if it had attained its mature state. 
Given this power, then, we may see in the Biorhiza an illustration of a youthful form which has acquired an egg-laying habit. Its wingless state shows it to be less perfect than its winged neighbours. But, as the old strain strikes true, so out of the root-galls come forth the typical and perfect insects, whose eggs in turn stop short of their full development, as it were, and give origin to the imperfect Biorhiza individuals.

All the same, if we did not know this curious piece of history, we might not have doubted that we were dealing with two distinct species of gall-flies. The lesson we learn is, that it is scarcely safe to assert, and never safe to dogmatise, about the exact relationships of living beings, because now and then they show a tendency to become decidedly " mixed." 


\section{XV. \\ ZA TRemarkable Thistory.}

THE story of the gall-flies related in our last article, reminds one of another very curious piece of insect history which is well worth the telling, if only by way of illustrating the remarkable complexity of habits into which animals are now and then wont to fall. The subject of this history is a small beetle known under the name of Sitaris, and to M. Fabre, an ingenious and painstaking entomologist, we are indebted for the details of its life-phases. The Sitaris itself is in nowise a remarkable animal. It is a beetle of small size, which ranks among its near neighbours the blisterbeetles and other familiar forms. To understand the story of this erratic insect we must begin by regarding the ways and works of another and different insect, a species of bee (Anthophora).

In its mode of life this bee is peculiar enough. Away in Provence, M. Fabre tells us, there exists a hard sandstone whose strata are interspersed with softer layers: and within these softer layers the bee burrows, as a kind of insect quarryman. Its nests are found in the shape of these subterranean galleries, each gallery or passage leading to a cell intended for the reception of the bee's egg. Now, in the autumn season, the Sitaris beetle proceeds to the domicile of 
the bee. The latter has filled its stone cell with honey, (on the surface of which floats its egg), the entrance to the nursery-chamber being thereafter duly plastered up. At the entrance of the bee's gallery the beetle lays its egg, and thus inaugurates a very singular course of events. The Sitaris egg is hatched out about the end of August or beginning of October, and the young beetle, an active grub with six legs of its own, appears on the scene.

Expectation might be aroused that, with a store of honey close by, the young beetle might begin its operations by an attack on the sealed nursery-chamber of the bee. But this expectation would be doomed to disappointment. All through the winter the young beetle lies, like Lazarus at the gate of Dives, uncomplaining and apparently forlorn. When, however, April comes, the youthful beetle awakens to activity: it searches about as if looking for food and lodgment, but nothing definite at first comes of its movements. The bees, meanwhile, have been also hatching out, the first of this race to appear being male insects.

But, as if they had been prematurely born, these bees lie listless and cold at the mouths of their galleries, and therefore in close proximity to the young beetles, in whom they seem to have thus discovered comrades in adversity. The time and opportunity of the young Sitaris have now arrived. For it fastens upon the young bee, and is aided in its attachment by the claws with which its feet are provided. The beetle is, however, playing a waiting game: it is only using the young male bee as a stepping-stone to a more suitable position. The female bees next hatch out, and with their advent a new epoch begins for the beetle.

The female bees emerge from the nest and commence 
their work of storing honey and of preparing for the development of the next season's brood. To one of the mother-bees the young Sitaris beetle now transfers its attentions. It is watching for one event in bee history-namely, the laying of the egg. When M. Fabre, puzzled at first to understand the behaviour of the young beetle, and supposing that all that it needed or demanded was food in the shape of the young bee or the honey, examined the nursery-cells of the bees, he found no indication of any attack from the beetle. When he offered the young beetle the larvas and chrysalides, the cells and the honey for food, it refused all. "Que voulez-vous donc, bestioles maudites?" remarked M. Fabre to the waiting beetles. Then came the revelation. The beetle was patiently watching, as we have seen, for the laying of the bee's eggs. When this process has taken place, the Sitaris springs upon it.

The bee-mother, poor insect, fastens up her cell, with its egg and its honey, under the idea that all is well with her progeny. But she does not enjoy even the small satisfaction of locking the stable-door after the steed has been stolen, for she actually makes the thief and the robber secure and comfortable beside her innocent offspring. The young beetle sits on the egg floating amid the honey as upon a raft. It is, however, a raft which is destined to serve as food for its bearer. The beetle begins to devour the egg. The honeystore is, doubtless, food, and good food to boot; but what is enough for one is not sufficient for two: so the Sitaris devours the rightful heir to the honeystore, and in about eight days' time the bee's egg has vanished. On the empty shell of the egg, as if itself representing a kind of hollow mockery, sits the 
beetle; and here it exhibits an important phase in the changes of form through which its development is carried out. The honey-store now begins to be utilised by this insect-thief. The beetle becomes, in virtue of its feeding, a fleshy, grub-like creature, which floats helplessly on the honey. Its mouth is buried in the sweet store, and the beetle, as M. Fabre remarks, seems to exist at the very verge of suffocation.

Bit by bit the honey is consumed. It is the nutriment out of which the young beetle is forming and developing its future adult organisation. A few more changes of form occur, and a few moults evince the rapidity of its growth. Finally, in the month of August, comes forth the perfect Sitaris beetle, which, laying its eggs at the doors of the bees in the succeeding autumn, will cause its progeny to repeat the eventful history through which itself attained the fulness of life.

That these foregoing events constitute a very remarkable history is, I think, a fair description of their nature and purport. In its way, the record of the Sitaris development is more wonderful, one might hold, than the habits of the ants in respect of their entertaining stranger-insects, for example. Thus we find certain ants keeping the eggs of the aphides or plant-lice, so common on all plants, during the winter in their nests; the ants, as Sir John Lubbock tells us, treating "these eggs as if they were their own, guarding and tending them with the utmost care."

In the case of our beetle, we see a far more complex habit wrought out to become part and parcel of the animal's development. What, at first, must have been a chance discovery - that of the honey-store of the bee-must have been subsequently complicated 
by the eating of the bee's egg, and by the passage of the beetle from the male to the female bee. There is an aspect of "biding its time" and of deliberate intent about the whole proceeding which teaches us clearly how a chance habit grows into an all-important phase of life.

In respect of habit, however, it is the proverbial first step which is the only difficult one. Once inured to a certain way of life, and once appreciating that this way is a safe and easy one, the animal or plant soon adjusts its existence to the new surroundings. This is the reward of changing one's quarters with success, that you come into a more comfortable way of livelihood. The Sitaris beetle evidently mastered this art of change. Its history teaches us that beneath our footsteps, and all unknown to most of us, there are thus ways and works often equalling, if not exceeding, in the accuracy with which means are adjusted to ends, even the most clever artifices of "the paragon of animals" himself. 


\section{XVI.}

\section{Z Display of IEnergy.}

WE are upon the verge of the "merry month," and the April weather has stimulated to the full all the promises of May. Everything living is awaking to the full after the winter somnolence, and even the ladies' Easter bonnets and costumes indicate that human nature somehow or other sympathises with the general delight in the prospect of a near summer-time, and a return to the genial warmth of the middle of the year.

There is not a bud or blossom which is not breaking forth into its silent song of gladness, none the less real because it is evinced to the eye rather than to the ear. "The birds on every spray" sing gaily of the rosy time of year, and thoughts of holidays and lazy days begin to animate the breast of the lord of creation himself. It is a poor heart, proverbially, which never rejoices, but I opine it must be a very sodden nature which does not feel that something delightful and pleasing has entered into life when the days begin to lengthen, and the warmth of May assumes a deeper and deeper glow.

We are greatly creatures of our environmentevery-living thing owes much to its surroundingsand the moods and tenses of the mind assuredly become attuned to a sympathy with the course of that 
nature which encompasses us, and of which, in truth, we ourselves are part. If, as Wordsworth puts it, every flower enjoys the air it breathes, so much the more must humanity, in a reasonable state of mind, be depressed by dull days and gladdened by the days that are bright and sunny. The seasons are too closely a reflex of our life to escape having an influence over us : hence, on the verge of May, a hundred voices are crying to us from the woods and fields, from the hills and valleys, from the cliffs and the sea, and bidding us rejoice and be glad in the summer revival of our land. We may well re-echo the voice of nature, and to those of us who are downcast and sorrowful repeat the message of summer-time, "And again I say to you, Rejoice!"

There is dead silence in the wood through which I am strolling this warm afternoon. A fortnight since, the buds were just coming to maturity. Now, the young leaves are out, and the sunlight is broken into varied pathways by the first of summer's harbingers in the way of the green clothing of the twigs and branches. I wonder if the thought ever occurs to folk unaccustomed to think of the abstract things of science, that an incalculable amount of energy is expended in the plenishing of the plant-world for its summer dress. To certain minds the words "force" and "energy" are meaningless terms; and I sympathise with the mind which, accustomed to the practical details of life, and to the realities of pounds, shillings, and pence, refuses or is unable to assimilate the abstractions or transcendentalisms in which the scientific mind delights.

But most ideas in science are easily mastered, if one can but think in terms of things rather than 
of names. Now, this word "force" and the term "energy" are legitimate and useful words enough in . science; and I question whether we can advance any distance at all in "the primrose way" of intellectual culture without knowing something about them. By "energy" we mean the "power of doing work;" and "force" is simply the equivalent of energy.

If I might put it practically, "force" is energy in action. You possess in your biceps muscle a store of energy, derived, of course, from your food. You buy so much energy when you pay the bill for your ton of coals; and you also acquire energy in the shape of the mutton-chop you anticipate having for lunch. When you raise your forearm by means of your biceps you liberate the stored-up energy of the muscle, and illustrate muscular force of power. When you burn your coal in the grate, the heat you obtain (the chief part of it, however, goes up the chimney) is liberated energy again, just as the motion of the steam-engine, which you might feed with your coals, is a part-result of the conversion of the locked-up energy of the Carboniferous plants into force. When you go cycling between lunch and dinner, you may assume that the energy which the grass-eating sheep stored up in the mutton-chop is being liberated in the force with which you propel yourself along the highway. I might add that, in the shape of the carbonic-acid gas and other waste matters you give out with each breath, you are giving back to the grass somewhat of the material it (through the sheep) gave to you. This is an illustration of the revenons à nos moutons idea, which is both apt and forcible, because it is so true.

In the wood to-day, under the influence of the sun- 
light, the plant-world is busy storing up "energy" for the future wants and possibilities of its life. Think of what this bright. sunlit day means to every leaf, every blade of grass, and every other green thing around you. Under the influence of the light, the living cells of the leaves, aided by the screen of green colouring matter each cell possesses, are absorbing the carbonic-acid gas which the atmosphere is offering them. They are decomposing this gas into the carbon and the oxygen whereof it is composed, and are storing up, or, at least, retaining, the carbon as part of their food, while the oxygen is being set free into the air.

The carbon will go to aid in forming the starches and sugars and other products of plant-life, and will thus help to build up the living fabric of the plant. Along with the water and minerals absorbed by the root, and a trifle of ammonia which comes chiefly from the soil, the carbonic-acid gas will then build up the plant. All this wealth of leaf and wood, of budding flower and unrolling frond around us, only represents so much non-living matter (or food) elaborated and transmuted by the cells of the plants into vegetable and living tissue. And all the beauty of the summerflowering, and the richer glory of the later harvesttime, which by and by will make glad the fields that today are only showing a faint greenness, will similarly arise out of the transformation of the crude matters of earth and air into the forms and tissues of our plants.

Now, do you suppose all this building of leaf and stem, this fashioning of bud and flower, is accomplished without a tremendous expenditure of that energy whereof we have already discoursed? You can really get no result in the way of work done in 
this world without paying for it, and there is no credit system in the transactions which Dame Nature arranges with the children of life.

Just as you and I had to purchase the energy whereby we walked to the wood in the shape of food and drink, so every plant has to buy the power ot doing its work (in the way of flowering and fruiting) in the shape of its water, carbonic gas, and other items of its diet. The plant is to many minds such an unobtrusive organism that what is certain to attract us in the case of the animal, is apt to escape us when we casually contemplate the world of trees and flowers.

Yet that all life is work becomes clear, if we can only realise the plainest of scientific truths; and in the wood to-day there is being both expended and stored up an amount of energy such as becomes practically unmeasurable by ordinary modes of thinking. There is not a plant around us within whose microscopic cells the ceaseless rush of living protoplasm currents is not proceeding. Every cell is a chemical laboratory in miniature, wherein wondrously complex operations are being carried out. There is complete silence around us, it is true. The very birds are enjoying their noontide siesta, and save for the chirp of the chaffinch, or the lazy croak of the crows in the rookery beyond us, not a sound disturbs the calmness of the day.

Think well of it, however, and learn that if (to use the expression of a master in science) our ears could be strengthened in their powers of hearing as our eyes can be aided by the microscope, and if we could hear more acutely than we do, we should assuredly be stunned by the roar of the vitality of the wood, as we are deafened by the noise of the traffic in the streets 
of the great city miles away. Some day our hearing powers may thus be increased. Till then you must accept what science teaches with the simple faith of the child. As you go on your way through this fair world, pause to think sometimes of the inner life that environs you everywhere, and learn how much he loses who remains ignorant of everything save the affairs of men. 


\section{XVII.}

\section{Fome Dlant Groundings.}

WITH the ordinary forms of plants and flowers everybody, of course, is very familiar ; but of the great kingdom of lower plant-life few persons, save botanists, know anything at all. The ferns we all recognise, and, what is more, delight in them, but even about the life-history of a fern there exists a very widespread ignorance. Below the ferns, which are aristocrats amid the lower groups of plants, come the mosses, fungi, and a whole host of still more lowly organised plants, beginning with the seaweeds and the Confervoe (which form the green scum on ponds), and ending with those microscopic free-swimming plants that are akin to the "germs" which people the earth, the water, and the sky.

At first sight, the Fungi, it must be confessed, do not present apparently any very attractive features for popular study; but the same opinion may be expressed of, say, an egg; and I know nothing more wonderful in the whole range of scientific research which equals in interest the story of an egg's becoming, and of the development of the germ and the few teaspoonfuls of yolk and white to form the complex living bird.

Toadstools and mushrooms are the familiar representatives of the fungi; but the order is a very large 
one indeed, and includes a vast number of species, ranging from plants of very respectable size to those of merely microscopic dimensions. The whole group of those organisms, which cause the diseases of plants known as smut, rust, mildew, blight, and the like, is included under the name of "fungi;" so that to the gardener and the farmer, the study of these groundlings of the vegetable kingdom can be shown to be fraught with very practical interest in view of the cure, or, what is better still, the prevention of plant ailments.

To begin with, we may be clear about one point regarding our mushrooms, toadstools, smuts, mildews, and the like-namely, that they are all of much simpler structure than ordinary flowering plants. Our buttercup or daisy is a complex being. It has its parts specialised to form organs of distinct nature - such as root, stem, leaves, and flowers. Again, when we take it to pieces under the microscope, we see that its tissues or layers are made up of a whole variety of different elements-cells and fibres.

Not so is it with our fungi. These, as a rule, have no such development of parts into roots, leaves, and the like, and all their tissues are built up of cells only. No fibres exist in them. They are soft-bodied plants, such as we know the mushroom to be. Yet this is not all, as regards our fungi. Taking them in their simplest phases, we find the essential part of each fungus to exist as threadlike branching filaments, which constitute the so-called mycelium. This is, in truth, the fungus proper, and most of the duties of life pertaining to nutrition, and so forth, are discharged by these creeping threads.

These latter, again, are white in colour. They 
possess no green substance, and be it noted that the presence or absence of green makes all the difference in the world to a plant. For when it does possess green matter, it can feed upon the materials it derives from earth and air-the water, carbonic-acid gas, ammonia, and minerals, which form the food of green plants at large. When, on the contrary, a plant has no green hue, it demands ready-made food in the shape of living matter. So that our fungi are daintier feeders in a way than their higher green neighbours. They subsist upon matter once living but now dead and decaying, while they sometimes feed upon living matter in its vital condition. Roughly, we might divide our fungi into those which feed on decomposing organic matter (e.g., our mushrooms) and those which exist on actually living bodies. These last are as much parasites as are the animals which lodge (and often board also) on other animals.

The manner in which the fungi reproduce their like is also very curious and interesting. The ordinary green plant, as we know, produces seeds. These, when planted in the ground, give origin each to a new plant. Development is, therefore, direct, as we may term it, in the green plants we see around us. But the fungi (and, for that matter of it, the ferns also) do not produce seeds. They develop minute living particles, known to botanists as "spores." When we study the spores in the light of their growth, we at once note how different lower plantlife is when compared with the higher forms of the vegetable kingdom. A common fern bears on the back of its fronds (not "leaves," please) certain brown bodies. Each of these brown specks is a collection of little cases called spore-cases. In shape, in ordi- 
nary ferns, a spore-case is like a fireman's helmet. The ridge or crest of the helmet in the spore-case is a ring which, by its contraction, splits open the case, and allows the little spores to escape and to fall into the soil.

Now, were a spore a seed, each would grow up directly into a fern. But instead of thus ending the matter, we find each spore to give origin to a leaf-like body, called the prothallus. This roots itself, and then produces in turn certain curious organs not unlike the stamens and pistils of higher plants. By the aid of these organs of the prothallus, the young fern-body is actually produced. It grows from the green leaf that arose from the spore, and when it has advanced in life, coiling up its first frond like the top of the bishop's crozier, the prothallus disappears by withering away, or by becoming absorbed in the young fern itself. Development in the fern is therefore from the fern to the spore, then to the prothallus, and from the prothallus to the fern again.

Now, in our fungi, much the same course of events has to be chronicled in respect of their development. The fungus produces "spores," like the fern, and not seeds. These spores grow upon special filaments which shoot up from the surface of the threads that we have seen to form the essential part of every fungus. In some fungi the threads are separate and

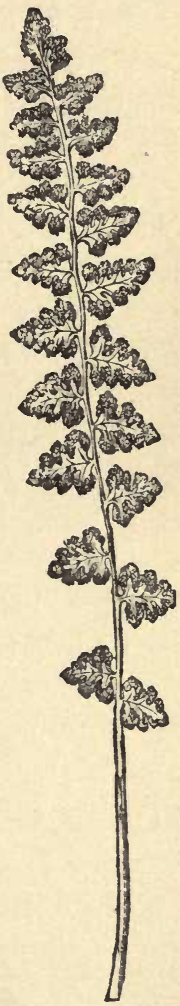

Fig. 23.

Fein-frond : Woodsia ilvensis. distinct, and then the spores are set free into the air, and help to form part and parcel of the great army of 
germs which the air-ocean bears. In this way, disseminated abroad, the spores find a resting-place here and there: now in the jam-pots of the housewife, now on the fine old crusted cheese, and now on a pair of boots which have been laid away in a damp condition.

But in cther cases, our fungi develop their spores in closed cases, whence they ultimately escape. The fungus-spore settles down, as we have seen, develops its threads, and then, latterly, we get back to the spore-bearing stage again. Some fungi may give origin each to several kinds of spores, and out of each kind a special form of the fungus develops. The exact personality of the fungus in such a case may be a matter very difficult of determination; and it would almost appear as though several distinct species had become mysteriously mixed up in their development.

In lower plant-life, however, we are prepared for this assumption of several forms and shapes, and finally in their habits we see illustrated the same tendency towards particular modes of life. Fungi nearly related are often found to attack very different plants. There is a mildew which attacks the lettuce, for example, and it is a ncar relative of another which infests the onion. Yet each fungus seems compelled to keep to its own plant, lettuce or onion : the one cannot trench on the other's ground. This says something for complicated habits even among the tenants of the slums of the vegetable world. 


\section{XVIII.}

\section{૬ome Curious valays of Dlants.}

Every one is familiar with the legend of the sunflower -how it turns its yellow face towards the orb of day. Perchance it was the look of the flower which suggested the story, but, curious as the tale may be, the presumed habit of the plant finds many a parallel in the vegetable world. There is a scientific term- "heliotropism," which means turning towards the sun (or light), and this term is, nowadays, used by botanists to indicate a very real and very interesting habit of plant-life.

Our sunflower rotates with the sun, it is true, and in so doing obeys what is really a primary law of vegetable existence. For ordinary observation will show us that most plants bend to the light if they are placed, say, in a room whereof one aspect is dark and the other open and bright. At the foundation of a plant's relations to light, to heat, or to any of the other conditions of its life, there lies of course the fact that it contains living matter, or protoplasm. We are given too much to regard plants as purely vegetative and half-living things, so to speak. We do not remember, until science forcibly reminds us of the fact, that the plants form one of the two great divisions of the living world, and that they rank equally with animals in at least possessing the matter of life. This habit of 
turning to the light, then, we may regard as truly a part of the plant's own nature, as is that of taking its own and appropriate food.

In truth, it is light which, with the plant as with the animal, rules and regulates most of the ways of life. Deprived of light, the whole constitution of the living being is altered. Its nutrition fails it ; its frame grows weak; its energies droop. There is a much closer analogy between the blanched leaves of a green plant grown in a cellar, and the pale face of a child bred in the slums, than we might at first sight be inclined to suppose.

There are certain plants, notably climbers, which do not exhibit for the sun the stable affection of most other plants. Tendrils, whereby many of these plants climb, are not influenced by the light. Were it so, they would tend to move away from the support to which they cling. The wisteria is an excellent illustration of a plant which, itself a climber by means of twining, winds itself regularly round its support without apparently regarding the light at all. Of the morning glory the same fact is true. But we do not know all when we make these bare assertions about the non-sensitiveness of tendrils and climbers to the light. If we watch a young climbing plant when it has just begun existence, and when it has raised its first leaf-buds and stem above the ground, we see that it is as sensitive to the light-as "heliotropic," in other words - as any other plant.

Later on, when the climbing habit develops and appears, this sensitiveness is lost. It has exchanged its early and primitive tendency-the universal habit of turning to the light-for another habit which better suits its new and acquired existence. Climbing, in 
other words, is incompatible with the constant desire to press forward to the light. The plant cannot both "have its cake and eat it ;" hence, as Darwin showed, twiners and climbers must consider their supports, and must let the question of light go by the board. From these facts, we argue that the habit of growing towards the light is really a universal habit of all plants. It has merely been superseded, in some cases, by another and newer habit, under which certain plants have contrived to flourish. It is like parasitism among animals. The parasites, once upon a time, were free and independent. Once betaking themselves to the fixed life, away go their feet, stomachs, eyes, and feelers; and a new and lower order of affairs is thus inaugurated. Still, in their young states, we find evidences that the parasites possessed all the appliances for movement and for independent life.

There is yet another point in connection with this bending to the sun which we must appreciate. It is this : that in all plants, which, as a rule, are less active than animals, the one great means and mode of altering their states is by the production of curvatures in their parts. This curvature we see when the tendril or the stem clasps the support in the case of a climber. We behold it equally well when we see a sensitive plant droop its leaves, or a moving plant swing its foliage right and left with an almost continuous oscillation. Peering into the tissues of plants with the aid of the microscope, we see the most vital parts and layers to be composed of minute bags or sacs, called "cells."

Of these cells there is infinite variety. Inside them, are the fluids of the plant, whereof water is the chief. 
Within them also is the living matter which constitutes the sum and substance of the plant's activities. A living plant cell is in a state of constant change. It is perpetually receiving, and as constantly giving off, water; and to the alteration of the cells of a leaf, a tendril, a flower-stalk, a stamen, or a leaf-stalk are due all the movements of plants. Now, in producing these alterations of cells, and in favouring cell-changes, light plays a first part.

Thus it is that the "heliotropism" of the botanist comes to be regarded as a powerful factor in inducing change in the vegetable world, and in carrying out the characteristic habits of each species. Left to themselves, in darkness, for instance, cells breed and multiply. There is no light to interfere with this dead level of cell-duty, as it were. That is why most plants really grow most rapidly in the night-time, and this even though the fall of the temperature is against quick increase.

The effect of light may be viewed as an interference with the process of growth in the cells of plants. If we return to our old friend the sunflower, we may be able now to explain why it follows the sun in his daily course. The effect of the light, which pours its rays against one side of the plant, in contradistinction to the other side, is to cause changes in the cells of the ormer side. There is set up an alteration of vital activity: growth recedes, as a power, into the background of things, and the result is to produce a curvature towards the light.

Thus, between light and darkness, our plants allow their complex lives to swing. But the instincts of the light may be paralleled by those of the darkness as regards plants. The young root, emerging from the 
seed, seeks the ground by an instinct as natural as that whereby the young stem seeks the light. There is curvature seen here again; and there are alterations of cells at work in the root as in the leaf or flower. That tendency we call, in botany, "seeking the earth" is as real a fact as the instinct of seeking the light; and both we have seen to be effected by the mechanical alteration of the plant's microscopic cells.

Yet, beyond all this, we have to deal with quantities and qualities which are not so easily to be estimated. I have said that the living matter of the cells has to play its part before we can have any manifestation of life at all. Beyond this, also, lies the mystic tendencies we name-inheritance and instinct. The plant lives and conducts its affairs as did its parent before it. The offspring live on the lines of their progenitors - until changed habits come to bring alteration into the ways of life.

Hence, even when we ask ourselves why a sunflower follows the sun, our answer is at best a tentative one. It does so because its cells are acted upon by the light, as were the cells of its ancestors. Beyond this, the "why" is all a mystery to us. The "flower in the crannied wall" still presents to our waiting eyes the problem of all the ages, and the puzzle which the wisest and best of men have attempted, but in vain, to solve. 


\section{XIX. \\ Tbe Jertility of Mature.}

There is no feature in the character of Dame Nature more plainly marked than her liberality and profuseness where the development of new beings is concerned. Witness, in proof of this assertion, the tons upon tons of yellow pollen or fertilising dust which are shed from the pine forests in the early months of the year, to be caught up by the winds and to be blown among the cones, to inaugurate therein the changes which result in the production of seeds. Much of this pollen is lost and squandered. Travellers tell us of this dust lying a foot deep or more on the borders of the great American lakes. Driven out of its course by contrary winds, it has perished, useless and forgotten.

The liberality of Nature, then, in this matter of pollen alone, would require to be of very great extent. Wherever wind-fertilisation takes place, it would seem as though, in aiming at that act through the medium of the air-currents, Madre Natura rained her bullets at the target from her machine-gun or Maxim, in place of aiming directly at the bull's eye with a rifle. In other words, she showers her loads of pollen not in the hope that all will be utilised, but that some particles here and there will fulfil their destiny. Now, this is 
a serious and wasteful business at the best. Only a person of huge and, indeed, illimitable resources, like Dame Nature herself, could carry on such a precarious and thoroughly spendthrift policy. Yet, it is a policy of fact, and every summer that comes and every spring that dawns upon us, testify to the fertility - I would say the over-fertility-of the powers and conditions that rule the living worlds.

Do you remember those lines in "In Memoriam," wherein Tennyson remarks of Nature's carefulness over the type, and her carelessness in the matter of the single life?-

"That I, considering everywhere

Her secret meaning in her deeds,

And finding that of fifty seeds

She often brings but one to bear"-

these lines are the poet's recognition of and protest against this terrible fertility of Nature, which seems to crush the individual that it may favour the race. Yet there is something to be said for all this apparent waste of means to gain an end. The whole process is one of favouring the growth of newer and higher types of individual life, after all is said and done. It is true that the crowd seems to occlude the individual interests; but it is only for a time.

Out of the mass which is thus favoured, you encourage your new and better individuals to arise. That is really the meaning of Nature's prodigality. She abhors the dead level, and desires to encourage a departure into "fresh woods and pastures new," and this can only be effected through the increase of the number of individuals who are to compete in the race for the better things which stand above life's dead 
levels. So far, then, we may discern a purpose beneath the apparent lavishness of numbers; and I confess that, but for some intellectual comfort of the kind afforded by the thought of fertility favouring progress and advance, I, for one, should be strongly tempted to think that the times were decidedly "out of joint" as regards Madre Natura and her lavish display of fertilising power.

Think for a moment of what this productiveness of Nature means. How many young, think you, does an oyster produce in its day and generation? If one says a million of eggs, the statement, I should hold, falls rather short than otherwise of the reality. Did these eggs each come to full fruition and develop into oysters, what a cheapening of that savoury mollusc would ensue! But of the million eggs, how many proceed to mature development? Not one in a thousand, probably. The delicate "spat" is devoured by fishes, killed by muddy water, and otherwise decimated by cold and other agencies. Only a miserable remnant of the oyster's progeny arrives at the stage of adult oysterhood. "The rest is silence," as Hamlet put it, in so far as the hundreds of thousands of oyster-progeny are concerned.

It is the same in many other places and departments of animal life. What do you say to the fertility of a cod-fish, a salmon, or a herring? A single cod-fish, it is calculated, will produce from $8,000,000$ to $10,000,000$ eggs; yet these swarms of eggs are liable to the attack of thousands of enemies (report, sad to relate, says among these enemies the father cod-fishes themselves must be enumerated), and only a miserable fraction of cod-eggs, herring-eggs, or salmon-eggs, therefore, ever reaches maturity. Were it not so, in a year or two 
there would be no room in the seas and oceans for the masses of fishes which would result from the fertility of Nature having full swing.

In lower life, as well, the same fertility is to be seen, contrasting markedly with the very limited rate of production witnessed in some animal species, whereof the elephant is a good example. A tapeworm, as an internal parasite, may, and does as a rule, consist of several hundreds of joints. Each joint contains several thousands of eggs, and the number of young tapeworm guests which would seem to be capable of being launched on a world of inoffensive hosts at first sight appears out of all reasonable proportion. Yet, as science teaches us, the chances of a tapeworm-egg ever reaching maturity of development must be ranked by many thousands to one.

Our parasite's egg has to pass through such a complex cycle of development, and its chances of destruction are so many and varied, that we need not wonder that while tapeworm-eggs are many, the adult parasites are so few. Or take the case of the plant-lice, or "green flies" (Aphides), that swarm on our plants in summer. These insects, as the gardener knows to his cost, are innumerable. They exist in myriads, it is true, but even their fertility is checked by cold, and by the many enemies that prey upon them. Thus, although the fertility of Nature is unbounded in one sense, it is checked in another. There is a prolific progeny as a rule; but it is prolific, first of all, because this is Nature's own way of encouraging, by sheer force of numbers, the production of animals and plants, out of whose ranks new and better individuals will step to advance the race and promote the change that makes for progress. 
There is another thought about Nature's fertility which has just been suggested - namely, that we find the extremes of productiveness in those cases in which there is most danger of the young not developing onwards to maturity. The elephant is fairly safe, it is urged; the oyster and cod-fish, in this respect, and the tapeworm, to boot, are anything but sure and certain of fulfilling their destiny. This thought, however, may be said to go hand in hand with that other idea already suggested-namely, that the greater the increase, the better are the chances of advance and progress.

Be this as it may, we can see that the great productiveness of Dame Nature is not without its reason. The fifty seeds which are lost are the real measure of the one which comes to maturity, and which does so because, probably, it is stronger and better fitted to bear the brunt of the battle of life. Better a hundred years of Europe than a cycle of Cathay, urges the poet. May we not parallel his saying by the remark that it is better to have fewer units in the field of life, and to find in these units the flowers of the flock, than to see all life sinking to the dead level of the mass, and to the humdrum existence of the crowd? 


\section{$\mathrm{XX}$.}

\section{Dandelíon Down.}

To-DAY, as I sit at an open window which looks on a pleasant meadow fringed with willows, marking the margin of the river, a dandelion seed has been wafted into the room by the summer breeze. The dandelion, familiar as it may be to everybody, is a flower which has locked up within its botanical history a very considerable meed of curious philosophy. I confess to possessing for that elegant flower, which is ordinarily and contemptuously named a "roadside weed," a high measure of respect. Primarily the dandelion is not one flower but many - a colony of strap-shaped blossoms, nestling cosily on the flattened top of the hollow flowerstalk. Pluck out one of those blossoms, and look at it narrowly by the aid ot a pocket lens. There is the yellow strap, toothed at the top, and forming the corolla of the flower.

Probably, once upon a time, when the dandelion blossoms were not packed so closely together (like human units themselves) this yellow strap was composed of distinct and separate petals. Its toothed or fringed margin would seem to indicate as much. Looking below you see the down or silky hairs which represent the calyx of the flower, or the green outer part you see so distinctly in the rose, in the straw- 
berry (where it is double) or in the primrose. Here the calyx is a mass of flossy hairs, and discharges, as we shall see, a useful purpose in the after-glow of dandelion life. Below, the little flower forms a tube, and inside the tube are the seed-producing organs. The pistil, wherein the seeds are matured, is that delicate stalk you may perceive rising in the middle of the tube. It is divided in two at its tip, and the ends curl over. On these ends the pollen, or yellow fertilising dust you see so distinctly in larger flowers, will be placed, so as to ripen and fructify the ovules into seeds.

Stamens, too, for producing the pollen, the little dandelion flower possesses, all united in a bunch

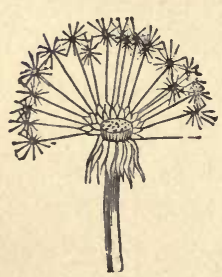

Fig. 24.

Dandelion Down. around the stalk of the pistil. So that inside this apparently insignificant blossom, one of the hundred or two which make up the dandelion-head, you find all the parts of a perfect flower. Little wonder that this race of plants flourishes exceedingly and multiplies apace, when you discover its colonial nature and its compound constitution.

After the blossom comes the fruit, and the dandelion pistils ripen in due season. The yellow leaves wither away, because, having served as flags and ensigns to the insect-hosts, which carry the pollen from one flower to the other, their mission is past and over. Seed-time in dandelion history is well-known. You behold the head of flowers converted into a perfect ball of downy hairs, and the children blow them off puff by puff to calculate the time of day, in the exercise of that popular folk-lore whereof childhood still retains many examples.

What has happened, then, to the dandelion-head as 
its seed-time has dawned upon it? Chiefly this : the silky calyx has developed apace, and has come to form wings whereby the seeds are carried hither and thither by the winds. Not content with producing abundance of seeds, Madre Natura provides for their dispersion far and wide over the face of the earth. There is a wealth of wonderment to be obtained out of the study which begins with a roadside weed and merges into the great question of the diffusion of plant-life at large.

The dandelion seed, which the wind has wafted tlirough the open window, speaks to us of ways and means of securing the propagation of the flowers by the cunning utilisation of the winds-just as in other plants the waters may bear the seeds to distant parts, or as others, again, employ animals to carry their progeny and to spread their kind broadcast. Indeed, from all we know about the dispersion of seeds, we are forced to conclude that the contrivance and ingenuity of Nature are nowhere more typically represented than in securing "fresh woods and pastures new" for the growth of plants.

Even in our dandelion there is found a certain noteworthy feature which is typical of many kindred devices for ensuring the due perpetuation of the race. When the flowers are being fertilised the head stands erect and prominent among the vegetation of the highways. Then, when the seeds are ripening, the stalk is lowered, and the flower lies horizontal or bent towards the ground. This device secures the efficient maturing of the seeds, and, when all is ready, and the ripened pistils or "fruits" are prepared for dissemination, the flower-stalk rises erect once more, and each puff of wind carries off the seeds, borne through the air on their wings. "Thistledown," in this sense, is seen to 
be a structure with a great purpose at its back. These "airy nothings" of the child represent some of the means whereby this earth has become peopled and pastured with the fulness of vegetable growth.

The floating dandelion seed, however, is but the beginnings of thought in this direction, as I have said. When you stroll through the garden or by the wayside, note how herb-robert, by an ingenious catapultarrangement, plays at "pitch and toss" with its seeds and scatters them abroad and around. If you come across a squirting cucumber anywhere in the south of Europe beware of touching it, lest you be greeted with a veritable explosion of seeds. Watch the ripe poppyhead, full of seeds, and note the little doors which lie just under the lid. You may understand then, how, when the flower-stalk sways to and fro with the wind, the seeds are ejected and thrown out from their parentcapsule.

Of winged seeds, too, there are many tolerably heavy kinds, which are dispersed by means of the wind acting on their parachutes. The sycamore seed has a double wing, as also has that of the maple, and the ash and fir are also to be reckoned with in this sense of wind-dispersed plants. When you stop to examine the burdock seeds, you will then discover how the animal is pressed into the service of the plant, for you may note the hooked hairs with which the seeds are provided and wherewith they cleave and cling to the hair and fur of sheep and other unsuspecting ministers of plant-life.

Nor is the service of the animal always unconscious. There is a South African plant whose seeds or fruits possess hooks of such a nature that, when the lion has innocently been made a carrier and disperser of these 
seeds, the king of beasts has been done to death by the torture and irritation they induce. The lion in attempting to free his hair from the seeds, is apt to find them adhering to his mouth, and the effort to get rid of the seeds is as often as not a hopeless task.

There is no space left wherein to ask you to remember the sticky seed of the mistletoe-a rare provision among our native plants - whereby it adheres to the tree which is to form its "host." It is a curious story, too, that of the dispersion of seeds by the aid of birds. You may read how Darwin, by the exercise of his patient industry, seeing possible results where a lesser mind would "pass by on the other side," moistened and tended the clod of earth which a friend had removed from the foot of a migrating bird. Out of this clod, in time, dozens of plants were developed, which, in the natural order of things, would have been carried by the bird over great tracts of land and sea. Think, also, how volcanic islands, rising from the azure main as primitive tracts of land, are peopled by the winged seeds which fall on their coasts and bring forth a covering of vegetation to cover the primitive barrenness of the earth. But more of all these things hereafter.

I may not discourse at present on the why and wherefore of colour in fruits as an aid to the dispersion of the seeds contained therein. The dandelion seed is enough for to-day, and opens the gateway of thought wide enough for you and me for many days to come. 


\section{XXI.}

\section{Tbe sidistletoe jougb.}

THE flight of Father Time brings round, in its due season, the days of holly, and the "mistletoe bough" decks the walls, and (in a Pickwickian sense), "more convenient" localities in the homes of the land. Perchance few of us give a thought to the debt we owe to the world of plants at the season of Yule. Holly and mistletoe are inseparable from the folk-lore of Christmas, and the forces, tendencies, habits-call them what you will-which have evolved the greenness of these plants, have contributed much to the grateful associations of the time.

When other forms of vegetation have died off or are sleeping out the winter's chill, the holly, with its green and red, and the mistletoe with its equally attractive, if quieter and more subdued hues, remain with us to remind us of hopes and aspirations extending far beyond the season of the snow.

I think there is a tacit reflection cast from these plants into human life, bidding us be of good cheer, advising us to tide over the wintry side of life, and inspiring us with hope for the future. The old associations of mistletoe and holly abide with us as part and parcel of our social life, and unconsciously affect us by their tale of life and vitality when most 
things else are quiescent and still, and give no sign of life at all.

Away back in the history of the Gauls, we know how the mistletoe played its part in the mystic rites of that race. On the sixth day after the first new moon of the year, we can see, in our mind's eye, the two white oxen placed for the first time under the yoke, and the High Druid, in his white garments, golden sickle in hand. We can see him cut the mistletoe from the oak, and behold the plant reverently received in a white cloth as it falls. Then comes the sacrifice of the oxen, and the distribution of the sacred leaves to the people. All these things, ideas, and ceremonies have long passed away, and have become merged in that "illimitable azure of the past" which receives so many of the hopes and fears of the human race; but mistletoe remains with us-a symbol of the reviving year about to dawn, and a promise of the new life which the advent of the spring will proclaim.

That something of the lower nature often commingles with higher things is, unfortunately, a fact of life that needs no new illustration. Mistletoe is a "parasite" on apple and oak, and parasites belong to the groundlings among life's children. There is no nobility in the character of animal or plant which attaches itself to another living being, either as a lodger or a boarder, or in the double capacity of an unbidden guest. Plant-morals, like animal-morals, are often of the grossly utilitarian type. If a living being is cunning enough to take life easy by absorbing the food which another child of life prepares for its own use, the parasite doubtless benefits by its assumption of the rôle of unwelcome guest.

But "the whirligig of time brings in its revenges." 
There is a stern decree of that implacable female, Madre Natura, which declares that parasitism includes the lowering of the form which sacrifices its vital independence to luxurious comfort and inglorious ease. In animals, legs, stomachs, eyes, and other belongings are swept away when the parasite, attaching itself to another animal, is found to have no use for the organs of free and normal existence. This is the penalty of parasitism everywhere-degradation and backsliding

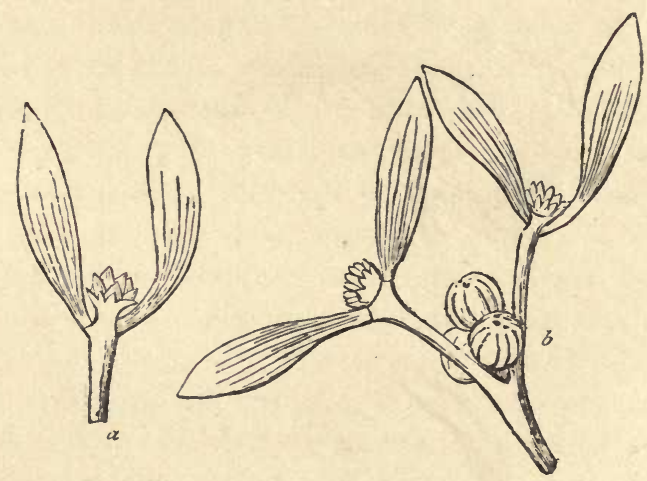

Fig. 25.-Mistletoe (Viscum album). a. Flower ; b. Fruit.

in the vital scale. Yet in our mistletoe there is one redeeming feature.

Parasite though it may be, it has still a saving clause in its botanical character. I have before me a piece of an apple-tree's branch. It has been cut through dexterously enough, and the relations of a sprig of mistletoe which has attached itself to the bough are rendered clear and distinct. The mistletoc is not merely a lodger on the apple; it is a boarder likewise. Like certain dissatisfied tenants nowadays, it insists on holding to its landlord, while it declines 
to pay rent in any shape or form. Into the substance of the apple-tree, the parasite has dipped its sucking roots, and a whole array of these roots is seen in my section, serving to drink up into the mistletoe-plant the sap which the apple-tree has made and elaborated for its own use. There is no intermingling here of parasite and prey. It is an attachment pure and simple for purposes of lodgment and food.

If you go back in mistletoe-life perchance you may trace the beginning of this curious habit. The berries of mistletoe, when examined closely, are seen to contain a very glutinous fluid. The ripe berry is, in fact, a mass of vegetable gum, which is developed in the rind or covering of the fruit. This gum is part and parcel of a distinct purpose in mistletoe-life. When the birds attack the berries and liberate the seeds, the latter, falling on the bark of trees, adhere thereto by aid of the natural glue they contain or possess.

This is the first step in the act of parasitism. The bird acts as the unconscious distributor of the mistletoe seeds, and the plant, which has tacitly bargained for this conveyance (through its offer of a free breakfast-table to the bird), then works out its own life-purposes. Once settled on the bark of the tree, the mistletoe seed, in virtue of its inborn instinct, appreciates its surroundings.

In the earth, where a respectable seed is at home, it would perish and die. On the apple-tree's bark it is in clover. It has found its haven, and now makes the most of its chance. Germination of the seed is soon set up, and then the radicle, which is simply the youthful root, penetrates the bark of the tree, and seeks out a special layer of the stem of its host. This 
is the layer, near the bark, through which the sap ascends.

Now, this fluid forms what botanists call the "crude" sap. It is on its way, in other words, to become perfected in the leaves of the apple-tree. Once in the leaves of its own proper maker, the sap would acquire all the properties which fit it for the nourishment of the plant. Why, then, does the mistletoe select the imperfect sap of its host, in place of drawing from the tissues of its prey the perfect material ?

The answer to this question brings us back to that remark of mine wherein I declared that a redeeming feature existed in the constitution of the mistletoe bough. Our parasite has not passed quite to the depths of life's degradation after all. It still harbours a habit of independent food-making which constitutes a saving clause in its moral character.

For the crude sap which it absorbs by aid of its roots passes into the mistletoe's own frame, and there undergoes a further elaboration. Into its leaves pass the undigested products of the apple-tree's work, and in the leaves the stolen sap is made fit for nourishing the parasite's own blossoms, and for developing the berries and seeds which are to lay the foundations of the new mistletoe race.

The green leaves of our parasite also teach us that it may and does do something more in the work of food-making. Green leaves always mean a power of absorbing from the air the carbonic acid gas which forms part of the food of every green plant. Your colourless mushroom will have none of this gas; it is a more dainty feeder, and demands something of the animal dietary. Mistletoe, percharice, is on the way to lower things. 
Parasitism seldom remains a stable habit of life; and if the forces of Nature work out their end-as, apparently, they have done in other plants - there may dawn a far-off Christmas season when mistletoe, having lost its leaves, and parted with the last evidences of its independence, will no longer remain to cheer the heart of man, or to grace the social life of Yule. 


\section{XXII.}

\section{Ibolly JBerries.}

THAT spray of holly in the smoking-room which remains over from the Christmas festivities, with its red berries gleaming from among their background and setting of dark green leaves, has been teaching me a curious story of plant-life as I lay lazily this morning enjoying a fragrant and soothing Havana. Outside there are holly-bushes fringing the lawn-tennis ground, and a sprinkling of snow has set out the greenness of leaf and the redness of berry better far than the neutral tint of the smoking-room wall. The thought which arose in my mind had reference to the uses of colour in fruit, and to the possible advantages which accrue to the holly tribe and to all its kith and kin which possess coloured fruits conspicuously displayed. Time was, when man's observation of things extended just so far as the things themselves.

Quite true; my metaphysical friends, I know, will argue for hours about "the nature of things in themselves." This smoking-room has heard learned talk, prolonged into the small hours, about Aristotelian notions and the Berkeleian philosophy of an outer world - which philosophers say we make out of ourselves largely or completely. But in the science of nowadays we have acquired the habit of going beyond objects to 
seek out their meaning. The holly-berries are pretty and pleasing, no doubt. Linnæus-cautious, observant old Swede-would have contented himself with a minute description of the holly tree. Every character of leaf, stem, fruit, and flower would have been duly noted as a guide to classification.

Nature, in those days, was regarded as a wellordered museum. "Here's a holly, and there's an apple," was the tacit summation of botany in bygone days. They were species-makers and variety-mongers in those times, and were uncompromising advocates of exact description and enumeration of the characters of animals and plants. We have changed all that, thanks to the master-spirits which have taught us that nothing in nature stands solitary or alone. There has been a tremendous searching out of the "reason why" of everything since the days of Linnæus. Books on botany, written, say, thirty years ago, are filled with dry details and detached facts. Now the dry bones of description are made to glow with vitality, and the facts are linked together like pearls on a string, to make up an interesting story of how things have come to be what they are. Holly-berries were probably as red and holly leaves were as green in the past cycles as they are now - and that was all. To-day, one wants to know why the leaves are green, why the berries are red, and what uses and purposes both serve, not merely as a part of holly-life, but as parcel of plant-existence at large.

Between fruits and flowers, in the matter of colour, there is a close and intimate association. Every schoolboy who is taught botany, knows that flowers are coloured to attract insects, while the insects in turn cross-fertilise the plants by carrying the pollen-dust 
from one flower to another flower of the same species. Colour in flowers, then, has a purpose all undreamt of . by the older botanists.

What of fruits? Colour here, in the logical sequence of events, must be credited with a purpose also. Let us see what that design may be. When you look at an apple or orange you are struck by the apparently big size of the edible part of the fruit, and by the relatively small size of the seeds. Compared with, say, the fruits of a buttercup, represented by the collection of little dry green bodies borne on the end of the flower stalk, the apple, orange, peach, plum, and cherry are grandiose in the extreme. The apple substance does not nourish the seed. There is no question of nutrition involved in the matter at all. The seeds are all ready to produce the new plants, and lie concealed within the apple, and cherry or plum stone, waiting their season and opportunity.

Why, then, all this big growth of eatable material? The answer is, "For the birds and insects and for any other animal agencies which will help the plant on its way of life." " The blackbirds that peck at the peaches and apples are Nature's servitors. They come for their food to the gardener's preserves, and as they split up the dainty succulent fruit, they liberate the seeds, and thus secure the prospect of fresh generations of plants. Here, then, is a philosophy of fleshy fruits for your consideration, and in it is involved a philosophy of coloured fruits as well. The colour attracts, and the fruit-substance rewards, the birds: and the plant gains through the liberation of its seeds and through the chances thus acquired of an early and satisfactory development in the soil.

The holly-berries, like the rowans and barberry 
fruits, are thus coloured to attract birds. In the barberry you see how the fruits are clustered, so as to mass the colour and to make sure of the fruit catching the eye of the bird-visitor. The rowan-tree has less dense clusters of berries, and the holly is still more modest in respect of its fruit-development. But what holly loses in the size of its clusters, it gains in the brightness of its berries. Against the dark green of the leaves, the berries stand out with great prominence.

Their after-history is instructive enough. A hollyberry is gobbled up by a bird with ease. What of the seeds the berries contain? Does digestion, which in a bird is a tolerably rough and mechanical process, destroy the seeds? Not so. The seeds, encased each in its dense tough covering, resist even the digestion of the bird's gizzard and stomach, and they are passed on uninjured through the alimentary tract of the animal. Thus liberated, and the bird being the gainer by its digestion of the soft parts of the berries, the holly-seeds fall into the soil and grow up each in time to the holly-tree.

Note again, how this interaction between bird and fruit serves another useful purpose. Birds traverse leagues of country in their peregrinations. They may thus convey the holly-seeds to regions hundreds of miles from the parent tree whence the berries were plucked. You begin with the colour of a berry, and you end by securing the distribution of holly-plants far and wide through the agency of the bird.

We owe much to the dispersal of seeds by such agencies. There is a plant of the New World, the American currant, which long ago was introduced into France, for the sake of the dark red juice of its berries, which was used to colour wines. At Bordeaux this 
currant was extensively cultivated. Man introduced the plant, but mark the greater influence of the colour of its fruits and the work of the birds. Now, the American currant is found universally throughout the South of France. It has spread also into Switzerland, and has reached the Tyrol.

You can, therefore, prophesy with considerable safety regarding plants and their chances of distribution, when you see these fruits and learn the story of their distribution. Holly-berries have social associations dear to the hearts of us all. They possess, however, in their redness and in their attraction for bird-visitors, a romance that is all their own. 


\section{XXIII.}

\section{Fome IIDicroscopic ffriendos.}

When a very thin film of blood is placed under a microscope of sufficient power, we observe that, so far from being a uniformly red fluid, blood is really as colourless as water. This apparent paradox between what we see with the unassisted sight and what is beheld under the microscope, is entirely explained when we discover that the red colour of blood is due, not to any inherent property of colour in blood as a fluid, but to the enormous number of red particles which float in it. What the microscope enables us to see is the clear liquid between the red particles it bears. To the naked eye, which is unable to distinguish minute objects, and which sees things only in the mass, as it were, blood naturally appears red. In any case, it will take its colour from its floating particles.

Some worms have green blood; this is due to the green hue of their blood-particles. An oyster or a lobster has colourless blood, because it possesses no coloured particles at all, but only white or colourless ones. The blood-particles we name "corpuscles;" and in addition to the red ones seen in our blood there are also white corpuscles. The latter are less numerous than the red, and we may calculate that about one white to 400 or 500 red corpuscles, is to 
be taken as a fair or average estimate of their proportion. The red corpuscles of the blood discharge a very important duty in the maintenance of our lives. They are the gas-carriers of the blood. They go forth from the lungs laden with the oxygen we have breathed in ; they return to the lungs charged with the carbonic acid gas which we have to breathe out. So far, then, the use and duty of the millions of red particles in our blood are not by any means matters of doubt.

The white corpuscles, on the other hand, possess a far more curious and eventful history. Each is a mass or cell of living matter- "protoplasm," as it is named-measuring in diameter the one twenty-five hundredth part of an inch or thereabouts. It also possesses a smaller and solid particle in its interior. Now, being a mass of living matter, our white corpuscle possesses powers of independent movement; and this first fact introduces us to a startling consideration. We possess in our blood millions of little living bodies, which are, in a sense, independent of us-autonomous subjects, as it were, of the body at large. They are not under our control in any sense; but live and move, and discharge their duties as freely as if they recognised no right or title of their possessor to question their acts.

Somewhere about the year 1846, Dr. Augustus Waller, observing the circulation in the finest bloodvessels - such as we can observe in the web of the frog's foot, and in other transparent textures of that convenient animal's frame-declared that he saw blood corpuscles, and especially white ones, insinuating their way through the walls of the vessels, and, passing out through these tubes, finally land.amid the tissues of the animal's frame. This observation, at first re- 
ceived with hesitation and surprise, was fully confirmed. It became known that the white corpuscles, instead of leaving the blood-vessels as a matter of rarity, executed that manœuvre as part and parcel of their ordinary life-work. They are seen to migrate regularly from their protecting vessels, and are observed to wander about, as it were, within the body, each on a roving commission, apparently uncontrolled by any of the familiar forces or conditions of the frame.

Matters remained at this stage of research for a considerable number of years. Not so very long ago, ardent observers, however, once again returned to the history of these wandering blood-particles. I have
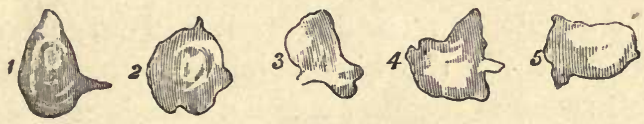

Fig 26.-A White Corpuscle of the Blood (I-5, forms assumed successively by one and the same Corpuscle).

always entertained an objection to quoting in popular papers names which are technical in nature; but, possibly, there will be no great risk of startling any of my readers if I add that these white blood-particles are now known as "leucocytes;" while, from another characteristic of their life and labour, they have also been named "phagocytes."

Watching one of these living particles on a microscope slide especially kept at the blood's own temperature, we can see it literally to flow from one shape to another. It imitates in this way the movements of many an animalcule in the pools. We may also see our independent white corpuscle seizing and digesting food particles, as if, in very truth, it were 
an independent animalcule. This power of feeding, we shall see, is an important characteristic of our wandering particle.

On this account it has been called a "phagocyte"literally an "eating-cell." In all ordinary animals, from man downwards, then, we see these white blood-cells, migrating from blood-vessels, passing out among the tissues, and thus showing forth an independence which is not without physiological reason or justifiable pretext. The further story of their life-work is interesting and may be readily understood. For it is now a matter of certainty that among all the servants of our bodies, we possess none more active, none more faithful, and none more necessary than our wandering cells.

When the young frog or tadpole attains a certain stage of development, and when it is about to exchange its water-life for the higher land-existence, the fishlike tail requires repression and demands extinction as part and parcel of frog-advance. Of old, we believed the disappearance of the frog's tail was due to a simple process of atrophy or wasting away. We know better to-day.

By close microscopic investigation, we are able to see a curious work proceeding in the tadpole's appendage. It swarms with white cells which have migrated into its substance from the blood-vessels. They are there for a purpose, and they work with a will. They are seen in the act of eating and devouring the substance of their possessor. The tadpole in this sense, and through its semi-independent whiteblood cells, is living upon itself, and eating up life's "principal" in place of living upon the interest represented by its food.

Within the bodies of these white cells in the tad- 
pole's tail, microscopists have been enabled actually to see the fragments of muscle and nerve they have torn from the tail substance. Little wonder that the tail "grows small by degrees and beautifully less" under such a vigorous attack; and in the gills of the tadpole (which disappear with the tail) the same devouring process is seen to proceed. Thus, the disappearance of the tail is a matter of vital action-as much so, indeed, in one sense, as its growth. It is a new experience of life to find certain of the living particles of the body set apart, as in the case of the frog, for the work of ridding that body of its encumbrance, and of assisting it to rise in the scale of life.

Nor is this all. In the water-fleas which swarm in every brook, the white cells have been seen engaging in a hand-to-hand fight with vegetable spores or fungi which gained admittance to the bodies of the fleas, and threatened to kill those animals. Like a ship boarded by enemies, the water-flea's body was the scene of a grim contest. As a writer puts it, if the white cells overpower and eat up the vegetable intruders, the water-flea lives; if the cells fail to overcome the invaders, the water-flea dies.

A further thought about these microscopic friends extends to human life. If our bodies receive germs which grow and multiply within our tissues, what is seen in the water-flea will occur within the human frame. There is a battle between our white cells and the germs of disease. If the latter are victorious, we fall ill of the fever or other ailment; if we escape the fever, our immunity is due to the victory of our microscopic friends over the germs. 


\section{XXIV.}

\section{કome SIDicroscopic SIDummies.}

THERE is a strong temptation in this spring weather to anticipate the search for life in the pools. Eager naturalists are already on the qui vive for the annual crop of objects for the microscope, and, collecting-bottle in hand, are to be seen every fine day "grubbing" for specimens, as the onlookers name the quest. One is tempted to remark, however, that, to find interesting specimens, it is not necessary to go beyond one's own rain-water barrel, or the gutters of the house-roof.

I have been reading anew to-day-incited thereto by the discovery of certain animalcules in some rainwater which had collected on my window-sill-the account of a remarkable discovery made by that worthy old Dutch naturalist, Leeuwenhoek, somewhere about the year I702. He was a great authority on microscope-glasses in days when that instrument was in its infancy; and as became an expert, was perpetually on the look-out for objects wherewith to test the powers of the lenses he had ground.

So it happened that " on the 25th of August," to use Leeuwenhoek's own words, he "saw in a leaden gutter at the fore part of my house, for the length of about five feet and the breadth of seven inches, a settlement of rain-water which appeared of a red colour. . . . I took a drop of this water," he continues, "which I placed before the microscope, and in it I discovered 
a great number of animalcules, some of them red, and others of them green. The largest of these, viewed through the microscope, did not appear bigger than a large grain of sand to the naked eye; the size of the others was gradually less and less. They were, for the most part, of a round shape, and in the green ones the middle part of their bodies was of a yellowish colour. Their bodies seemed composed of particles of an oval shape. They were also provided with certain short and slender organs or limbs, which were protruded a little way out of their bodies, by means of which they caused a kind of circular motion and current in the water: when they were at rest and fixed themselves to the glass, they had the shape of a pear with a short stalk."

So far, quaint old Leeuwenhoek. What he saw in 1702 and discovered in that year, any one may see and admire to-day. For the species of animalcule he described was the common "wheel-animalcule," or Rotifer vulgaris, as it is scientifically named. This animal forms a capital study for a young microscopist. As shown forth in our illustrations, its main features agree tolerably well with the description of the old Dutch naturalist. The "certain short and slender organs or limbs" which he noted as belng "protruded a little way out of their bodies," and as causing currents in the water, were the so-called "wheels" from which the animalcules receive their familiar name. These "wheels" may be seen at the head of the animalcule (figs. 27 and 28), fringed with delicate lashes or cilia, of the delicacy of which no drawing can give any idea.

The cilia are threads of living protoplasm, which on their own account keep up a perpetual vibratile motion, as in the gills of the oyster and mussel, and in the 
sponge. It is this ciliary movement which, acting like so many oars, drives the animalcule hither and thither by rotary movement. But, all the same, it is not the wheels themselves which move. This is a mistake in observation commonly made by young observers. They fancy the wheels themselves rotate; whereas this appearance

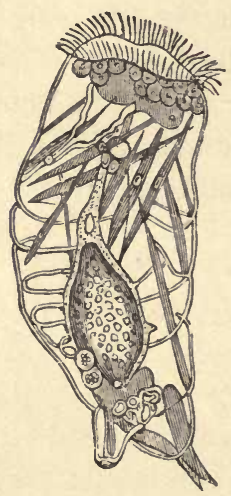

Fig. 27.-Rotifer: Male.

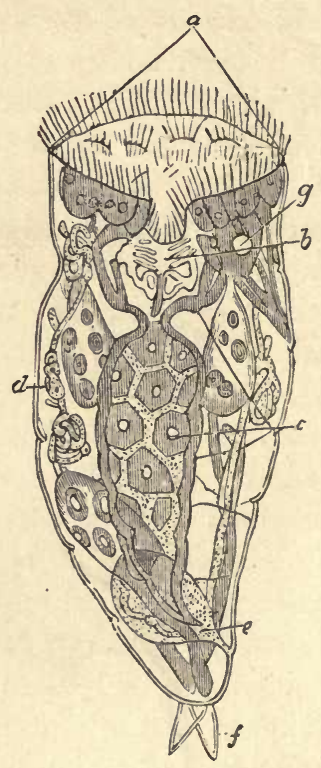

Fig. 28.-Rotifer : Female.

$a$, The ciliated wheel-discs; $\delta$, the jaws ; $c$, the stomach; $d$, water-vessels;

$e$, the contractile water-sac ; $f$, the pincer-like tail ; $g$, the "eye."

is produced by the cilia, each bending rapidly in its turn, and so quickly straightening and bending again, that the wheel appears itself to be in action. The wheels, as Leeuwenhoek tells us, can be withdrawn or protruded from the body, but it is their cilia which alone are active. The optical illusion here is similar to hat whereby, when the stalks of wheat or corn bend 
beneath the force of the wind, we can well nigh fancy that real moving waves pass over the surface of the field.

Hurrying through the water, then, we find our wheel-animalcules propelled by their ciliary lashes. As the mouth opens below the wheels, we can understand how particles of food are swept therein by the same action which serves for movement. Then, when the animalcule fixes itself, as Leeuwenhoek noticed, by its tail-pincers $(f)$ and still keeps its lashes in action, we may note how, like a steamer moored to the quay, but whose paddles continue to revolve, the animalcule's currents will act most forcibly in the way of food-getting.

Our common rotifer is the type of a very large class of animalcules, many of which, like itself, are freeswimming in habits, while others build elaborate tubes as dwelling-places, and exhibit more of the stay-athome philosophy than their roving neighbours. But that feature which most excites our interest in this curious class of wheel-bearing specks, is a certain wondrous power they possess of surviving and reviving after being exposed to conditions of hardship which would certainly extinguish the life and vitality of all higher animals, and indeed of many other animalcules. Old Leeuwenhoek was the first to bring this fact under notice, and numerous experiments have been made after his day by way of confirming his observations. He shall tell us his story, once again, in his own words :

In October I702, he observes, he caused the dry débris of the house-gutters to be collected. About a teacupful was gathered and placed in his desk in paper. Then, "after the above-mentioned dry substance had been nearly twenty-one months in the paper, I put into a glass tube, of an inch diameter, the remainder of 
what I had by me, and poured upon it boiled rainwater after it was almost cold. . . . Some hours after, I discovered a few [animalcules] that had opened or unfolded their bodies, swimming through the water." On other occasions, having dried up his animalcules in a glass tube, Leeuwenhoek left them for a day or two in this desiccated state. He then "invited some gentlemen to come and partake of the agreeable spectacle with me-that is, to see how the said animalculæ would divest themselves of their globular [i.e., their dried] figure, and swim about in the water." After satisfying themselves that the wheel-animalcules were really dried, some water was poured into a glass tube. "Then the gentlemen took the said tube into their hands, and viewing it one after the other through a microscope, they saw the animalculæ, after the space of about half-an-hour, beginning to open and extend their bodies, and getting clear of the glass, to swim about the water, excepting only two of the largest of them, that stayed longer on the sides of the glass before they stretched out their bodies and swam away."

Wheel-animalcules have similarly been revived which had been preserved dried for four years, and the late Dr. Carpenter dried and revived some specimens at least six times. Now, what has science to say to this drying and reviving of animals possessing delicate organs and structures? Almost nothing. We cannot even picture to ourselves the state or condition of the mummified wheel-animalcule. Water is an essential constituent of the bodies of every living thing. Do these animalcules, then, store this essential part of their tissues despite the drying ? or do they contrive to exist as realistic microscopic mummies, waiting for the return of the reviving fluid? Who can say? 


\section{XXV. \\ Tbe valorkers of the JBody.}

Some days ago a person remarked in my hearing that, while science dealt with both the big things and the little things of life and nature, it had in reality thrown very little light indeed on the more intricate bodily processes in virtue of which life is carried on. The plaint of my friend was that science knew about things "in the rough," but could not descend to take cognisance, in the same degree, of things of minute estate.

"So much the worse for science and mankind at large," I replied, "were your assertion true." As a matter of fact, there is no field of inquiry which has yielded such a large harvest to the truth-seeker of late years as that of microscopic research. There is scarcely a great discovery which has been made within the past decade in which our knowledge of the infinitely little, as shown forth by the microscope, has not figured most prominently. Disease-germs and countless other lower forms of life have been traced out in their development and tracked to their origin. Living things, whose dimensions are to be estimated by the thousandth parts of inches, are as well-known to us to-day, as is the ostrich or the elephant.

So far from the "little things" of the universe 
escaping our attention, I should be inclined to maintain that they largely monopolise science to the exclusion . of the big things. We are beginning to find out, in fact, that only by knowing something of the actions which proceed in the lower byways of life can existence in the main be understood at all. Hence, if any preparation for a knowledge of humanity be required, I should say one would find it in a microscopic study of what the ditches contain, and of what a leaf harbours. "The proper study of mankind is man," said the poet of Twickenham. To this very proper aphorism (in its way) science adds that the only safe preparation for the study of mankind is the knowledge of what lower life is and of what lower life does.

The remark of my friend suggested that within the compass even of human structures (and that strictly following out Pope's aphorism) one may find many phases of life such as will warrant the declaration that to the microscope we owe a vast amount of our knowledge of ourselves. It has often been asserted that man is a microcosm-a world within himself; and this is highly true, if we apply the saying to the microscopic structures of his frame.

No sooner do we begin to investigate the composition of man's tissues than we discover that, so far from a human being having any right to be regarded as a single entity, he might claim a title to be considered a compound or colonial organism. One man in his time is said by the Bard of Avon to play many parts. Physiologically, it may be said, man is very many parts or entities working together to form and to maintain an harmonious whole. This statement is easily proved. We do not speak without knowing when we make such an assertion. 
Glance through the body's constitution, and you will find, first of all, that, wherever you have life and vital activity, it resides in a particular kind of living jelly which everybody knows (by name, at least) as "protoplasm." This is the "matter of life"-it is life-stuff, in the truest sense; since no other matter on the face of this earth, save protoplasm, shows the phenomena or actions of life.

Now, what is true of a man's body in this respect is equally true of the body of every other living thinganimal or plant. When we come to investigate how this protoplasm (of a speck of which, the whole body in its germ-state once consisted) is disposed in our frames, we discover that it is represented in its most active state by microscopic bodies to which the name of "cells" is given. Here and there, the protoplasm has been worked up to form fibres and other structures (as in muscles and nerves); but the active, living elements of our frames consist, undoubtedly, of cells.

What, then, is a cell? Imagine a speck of this living matter, averaging, say, the one four-hundredth of an inch in diameter, of rounded shape, bounded by a kind of envelope, and having a particle (the nucleus) somewhere or other imbedded in its interior - and you will have a fair conception of what a cell of ordinary size and form is likely to be. Some cells we know of-nerve-cells, indeed-average only the one fivethousandth of an inch, or less, in diameter; and between big cells and little cells there are, of course, all gradations in size.

These cells, then, are the workers of the body. They are the population of the vital kingdom. The democrats are the cells-useful and necessary, and respectable members of society - which toil and labour 
to build up bones, to form muscles, and to make the various secretions. The aristocrats are the nervecells, which are by no means an idle plutocracy, however, but which work hard enough in the ruling, direction, and governance of the frame.

There is perfect division of labour in the living state. One group of cells does not interfere with the work of another group. Each piece of labour, from the building of bone to the making of gastric juice, is carried out independently and thoroughly by workers set apart for the given purpose. The economy of a bee's hive is not more rigidly ordered than is the work of our own body in respect of its labourers and their specific duties; and in the vast proportion of their affairs these workers of ours are self-directive, even while they own the supremacy of brain and nerves as their controlling power.

If we think of the countless operations which have to be undertaken from hour to hour to maintain our bodies in action, we may begin to realise what perfect co-operation really means, and what this colonial constitution of ours implies. For example, saliva has to be secreted, for the purpose of digestion in the mouth, and for other functions as well. This fluid is supplied by three pairs of salivary glands.

Now, the working and essential parts of these glands are living cells, which, out of the blood (as the raw material) supplied to the glands, secrete saliva, which is the manufactured product. Again, tears have perpetually to be made for washing the eyes. This secretion is supplied by a couple of tear-glands. Here, again, are cells, different from those of the salivary glands, and making out of the blood a very different secretion to that of the mouth. The cells of the gastric glands 
of the stomach make, from the blood, gastric juice. Again, we see a change of duty as we pass to a different set of cells. The cells of the liver compose that large organ, and discharge its multifarious duties. They are the living units of which the liver is composed, and are thus part and parcel of the living colony we term our body. The cells of the sweetbread make the digestive juice of that gland-another change of duty and another race of cells. The brain-cells guide and direct the body's highest acts equally with lower nervous operations.

Cells in the skin repair our wounds and throw off other cells which are cast away as the outer skin wears. The bone-cells renew and repair that dense structure, and build up the solid portions of the frame. In a word, every act of life is performed by the cells : each group of which remains distinct as a colony of workers charged with the performance of a specific duty. Truly, then, it may be held that our life is a divided existence physically; while from another point of view it is an harmonious existence, because of the perfect co-operation of these wonderful workers of the body-the living cells. 


\section{XXVI.}

\section{Germs: Good and JBad.}

TURNING out the contents of a portmanteau the other day, a pair of boots, which had evidently been deposited therein in a damp condition, came to light covered thickly in some parts with a growth of blue mould. To the attentions of this mould, of course, no housewife is a stranger. It grows on her cheese and invades her jelly-pots, and does not despise even damp boots, as we have seen, in its selection of a local habitation. The question of the mould's origin leads us in the direction of more than one great and grave theory regarding the beginnings of life at large.

Where the mould comes from may best be answered, as a philosophical query, by saying that it springs from a germ or germs, derived from a parent-mould. These germs, microscopic in size, are carried by the air, and are given off from the parent-mould as minute living particles. Like driftwood on the sea, they are borne hither and thither in company with many thousands of neighbour-germs, like and unlike, and when they find a suitable soil (as in the cheese or the jelly) they spring up into the mould whereof they are the early and legitimate representatives.

The air around us, as Tyndall long ago proved and expressed it, is a "stir-about" of minute particles, 
some of mineral and inorganic nature, others of organic and living kind. It is an ocean having particles, living and dead, for its floating things; and the living particles, in brief, are the "germs" whereof we hear so much that is interesting in the science of the day. It is true that we are encompassed about by a great cloud of living particles; but it is not true to assert that these particles are all equally noxious to man or equally innocuous in so far as human interests are concerned.

Some germs, like those of the blue mould, may be deemed harmless enough in their character. Others again, like those of the yeastplants (fig. 29), are more destructive, it is true, or may be sometimes pressed into the service of man. That bottle of claret you left uncorked after dinner two days

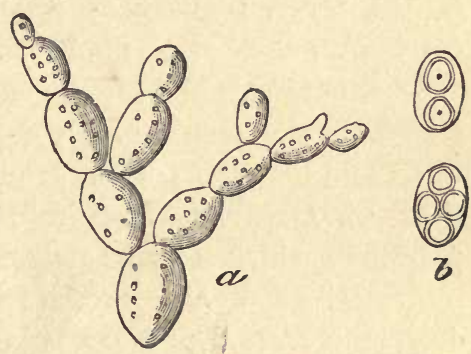

Fig. 29.-Saccharomyces cerevisia; $a$, a budcolony; $b$, two spore-forming cells. ago has gone to the bad. You declare it to be as sour as vinegar; and well may it be so, for vinegar it has become. Into your wine from the air, there dropped sundry microscopic germs of yeast-plants. These bred and multiplied in the soil they found ready to hand in the shape of the wine. Through the exercise of their own chemical powers they produce vinegar by a process of fermentation, just as certain other and nearly-related yeastgerms manufacture alcohol out of sugary solutions.

By the air also are carried the germs of diseases; and that many of our epidemics are air-borne in their nature and propagation, remains a sure fact of health- 
science. These germs of disease, dispersed broadcast, like the germs of the yeast-plants and of the blue moulds, seek a soil in the shape of the animal frame. Once found, this soil is utilised, and there is witnessed in the case of the body an analogous process to that seen in the wine. The little leaven (of disease) which leavens the whole lump (of the body) is exactly represented by the fever-germ. With the Apostle, one might go further and assert that, sown in weakness, the germ appears in strength. In each case the little living particle, whether of the mould, the yeast-plant, or the fever, reproduces its like. It multiplies exceedingly; the few germs become thousands, and all we see happening, alike in fermentation and in the fever, is merely the result of germ-growth. "Like begets like," and thus the germ reproduces in each case, sometimes directly, sometimes indirectly, the likeness of the parent to which it owed its origin.

Questions of size are always difficult to settle or determine from a popular point of view, and, when we seek to gain some adequate idea of the dimensions of germs, we are met with the difficulty of translating into terms of common life those of the infinitely little. If we speak of a germ which in length is the one tenthousandth part of an inch-that is, equals one part of an inch which has been divided, as to its length, into ten thousand parts - we utterly fail to grasp any notion of the size indicated. An appeal to figurative description, while more graphic in character perchance, yet leaves us with the dimmest conceptions of the dimensions of germs.

One writer tells us that on the area of a single square inch we could place, in a single layer, a population of common germs or bacteria, one hundred times 
as great as the population of London. Graphic as is this estimate, the idea of the actual size of the individual germs remains simply unattainable. It is this diminutive size compared with the great results in the way of disease certain of these germs may and do produce, which is more than sufficient to appal us.

Think for a moment of that fatal "wool-sorters' disease" which was formerly prevalent in Bradford. This ailment is caused by the entrance into the human frame of a minute germ, or bacillus (fig. 30), with which we are, microscopically, perfectly well acquainted. Sown somehow in the body through handling the wool of animals which have died of a similar disease (known in the animal as "splenic fever") this particle grows and multiplies as we have seen, and kills mankind through its abundant self-reproduction into thousands within the human tissues.

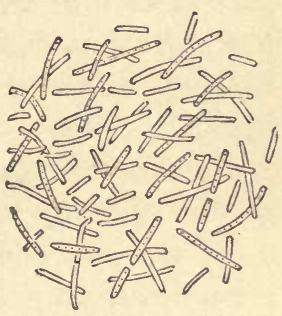

Fig.30.-Bacillusanthracis.

Upon human life it would, therefore, seem that disease-germs work their will unmolested. Yet this is by no means the case. Science has, in truth, been up and doing for years past, teaching us how we may scorch and destroy these particles, how we may limit their spread, and how we may protect ourselves and our goods and chattels against their attack. We are far from being helpless in the war we wage against germs, and every year that passes over our heads proves this statement true. The deaths from germproduced fevers and allied ailments show a steady decrease year by year, and in due season we may reduce such a death-rate to a miserable minimum if 
the people could only be well trained up in the sanitary ways wherein they should safely and readily walk.

But all our germs are not hurtful, as we have seen, and some exercise in the domain of Nature a decidedly useful function. Long ago, De la Tour showed the world that fermentation was not a result of death, but a consequence of life. It was the result of the growth and multiplying of the yeast-plants in their appropriate soil. Similarly, we open our eyes to the fact that putrefaction and decay are really works and actions wherein the omnipresent "germs" are playing the beneficent part of natural scavengers. They are removing from the earth's surface the fragments of life, and are preventing the world from becoming a perennial charnelhouse.

Still further may you dive into the useful ways of germs, aided by the eye of science. Darwin has told us of the part played by the earthworm as an underground farmer. Fertility of ground is brought about by the perpetual turn-over which the sub-soil receives at the hands of the worm. Our germs probably accomplish as much for us in this latter direction. They break up and decompose the refuse of life and aid its incorporation with the soil everywhere.

If the world might be much the better for the absence of certain germs, it is no less true it would certainly be rendered much the worse by the absence of others. If, on the one hand, certain germs kill or wound us, others, again, make the world purer and sweeter as the result of their work. It is in this, as in so many other things, we are apt to grumble at things as they are because we do not see, or care to notice, the reverse and kindlier side of the medal. 


\section{XXVII. \\ ż Contusing Case.}

A FRIEND, grubbing about amid the awakening life of the pools which summer is fast ripening into maturity, brought me, in a phial of water, the other day, a collection of curiosities which he demanded I should name and describe for his edification and instruction. It is often a hard task, that of satisfying people who are "wanting to know." They expect science to be equal to all things in the way of replies to questions which are still the inexplicable problems of philosophers among us; and they are proportionately disappointed when the answers desired are not forthcoming.

My friend's phial of dirty water, however, contained a good many objects familiar enough even to the tyro in microscopic science. The life of his bottle had been awoke from its winter sleep by one or two of those warm days of spring weather wherein we rejoiced a short time gone by. There were one or two Amocbas - masses of protoplasm, slowly elbowing their way from form to form across the field of the microscope; and a "sun-animalcule" was likewise busy enough in the way of food-getting.

A mother Cyclops or two, and a Daphnia, both water-fleas of well-known nature, appeared to be lively enough, if movements in these animals are to be taken 
as a test of vitality; and a lively worm of something more than microscopic size was similarly wriggling in and out of the hollow slide, and upsetting my coverglass in its attempts to gain a view of the bigger world beyond the water-drop or two in which it was contained.

But that which most excited the wonder of my friend was a lively little ball, which kept perpetually gyrating, as it were, beneath his eye, and appeared to defy recognition as approaching in nature to any known animal-form. Here the eye lighted upon a microscopic globe, whirling over and over in the water, and not exceeding in size the one-fiftieth of an inch or so.

It is a hollow sphere, studded at intervals with green spots or specks, which are connected together by threads or processes, imparting a network-like aspect to the structure. The source of its movements is not difficult to determine. Each of the green specks has attached to it a couple of delicate lashes (or "cilia"), similar to those borne by the specks on the margin of the globe; and by the vibratile play of these lashes, this living globe is made to gyrate within its native waters. Inside the globe (Fig. 3I), we see other and smaller spheres. These are youthful globes, which, by the death and cisintegration of the parent-globe, will escape into the water, and begin life each on its own account.

Close examination by a higher power of the microscope shows us that each of these greenish masses which dot over the mass of our globe is a distinct living particle. It consists of a speck of living matter (or protoplasm) coloured through its containing particles of the green matter we see familiarly in plants. 
This matter is named chlorophyll. There is in each green mass a red speck, which some biologists name the "eye-spot;" and in each of the living masses we see, besides, one or two spaces which "beat" and contract and expand as if they were rudimentary hearts of one kind or another.

Now, if our globe thus turns out to be simply a collection of green particles, each living, each connected to the other particles, and each possessing its couple of lashes or "cilia" to aid in propelling the globe through the water, the further question, "What is it?" at once arises. This was the inquiry of my friend, just as it was the inquiry of many a puzzled naturalist in former days. In the days of Ehrenberg, the organism was named the "Globe-animalcule." It was regarded as an animal, or rather as a colony or aggregation of

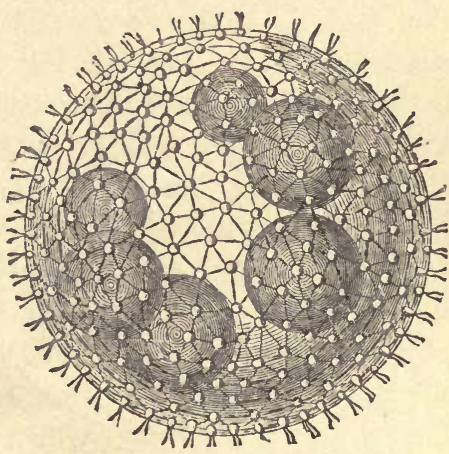

Fig. 3r.-Volvox. animals, and as such was classified among the animalcule hosts themselves. But this was in the days when the botany of the lowest plants was an unknown and unformed science.

Let us see whether Ehrenberg's epithet can be justified. That the "globe-animalcule," as it once was named, or Volvox, as we had better name it now, has apparent claims to be regarded as an animal, may no doubt be an assertion easy of proof to the unsophisticated mind. Does not it move? - and is not movement a feature of animal life which stands in contrast 
to the fixity of the plant?-are queries at the mere mention of which, I am sorry to say, scientists will not repress a grim sarcastic smile. If you hold that it is an animal because it moves, then what are you to say to the fact that thousands of the lowest plants are never rooted and fixed at all?

And what, further, will you reply to the observation that many true animals are rooted and fixed throughout life? There are your sponges, your anemones, your corals, your zoophytes, and your sea-squirts, all of which are fixed creatures but true animals, nevertheless. So that you observe the mere fact of motion does not prove that a living being is an animal; and it certainly does not disprove the assertion, contrariwise, that it may well be a plant.

The volvox before us is, in truth, an excellent illustration of the difficulty which attends us when we attempt to distinguish animals from plants. Not that it is difficult to separate higher animals from higher plants. There is no danger of confusing a cow with the grass it eats ; but, then, there are other and much lower animals in the world than cows, and many plants lower than the grass. When we face a living being like our volvox, we see the greater difficulty which arises-that of saying in which kingdom of living nature we are to put the lowest members of the world of life.

Now each of the green specks in the volvox might be an animal, and each might be a plant. Because the specks are green, and because they make starch, are facts forming no barrier to their being animals; for many true animals (like the "hydras" of the pools) manufacture the same green colouring matter we find in plants ; and many animals, including even man him- 
self, are starch-makers. What, then, to make a long story short, is this volvox? With its plant-like colour, it may be a plant; with its motion, and the structure of its living specks, it may be a mass of animals.

I reply, it is a colony of very low plants massed together and living a kind of co-operative existence. If you could trace out the special fashion the volvox possesses of reproducing its kind, you would be able to detect many and close likenesses to the ways of the lowest plants. In its preparation for, and production of, the bodies which are to develop into new globes, the volvox is seen to be a true plant, and to possess its nearest relatives among the great tribe of which the seaweeds and many other familiar forms are characteristic examples.

The closer knowledge of science often dissipates the mystery surrounding the nature of living things. But even under the light of such knowledge the answer to the question, "Is this thing or that (in lower life) an animal or a plant?" must appear to ordinary mortals on many occasions, as a confusing case. 


\section{XXVIII.}

\section{Jflies.}

THIs is emphatically the heyday and holiday of the flies; and for the last half-hour my efforts to secure an untroubled siesta have been frustrated by the blandishments and attentions of a particularly energetic member of that tribe of insects. Once upon a time I was captivated by an enthralling account of the adventures of a bald-headed man with a fly. Out of these incongruous elements the author evolved a most thrilling recital. The bald-headed man lay asleep - this was the prologue to the drama. Act first was the descent of the fly on his head, and his awakening himself from slumber by the energetic slap which he gave his cranium in the hope of killing the intruder and trespasser.

Then began act second. This was the arousing of vengeance. The bald-headed man procures a towel, and lies in wait for his enemy. Effort after effort to secure his prey fails. He then sinks to rest. The final act of the drama witnesses his waking up once again on the fly's invitation to combat, conveyed this time by tickling the hairless man's nose. He seizes his towel once again and pursues the insect. The towel knocks over a pair of costly vases. Then the inkstand is knocked over, and he mops up the ink from his carpet with his towel. Off he goes again in hot pursuit. He sends the end of his stick, to which 
he has secured the towel, through a pane of glass. Finally, he brings down the chandelier with his stick, just as the fly sweeps victoriously out of the window, and the bald-headed man is left wiping his face unconsciously with the inky towel. This is the final tableau, and, of course, brings down the curtain.

Now, there is much to be admired in this tale of a fly ; and one can sympathise deeply with the pursuer of the insect race. For an amazing, irritating, temperdestroying fiend of an insect, commend me to the common or household fly. Other insects (which shall be nameless) bite you and cause groaning and lamentation, especially in the watches of the night; others sting you with an honesty of purpose that leaves nothing to be desired; while others, again, eat your clothes and destroy your furs wholesale. But they are all fairly bearable in their way. It is your wretched fly which possesses a gift of irritating you simply and purely, and of making you get heated and vexed without adequate cause - a property this, by-the-way, which I once heard an ungallant and long-suffering husband attribute in perfection to his mother-in-law.

The one consolation about the fly is that it has an interesting history both personal and retrospective. Thus it is a member of a group of insects to which the learned in insect lore apply the name of Dipterathat is, the two-winged order. For the fly wants the hinder pair of wings which most other insects possess, and it shares this character in common with all true flies, whereof the gadflies, mosquitoes, gnats, and so forth are excellent examples. The hinder pair of wings, however, is represented in the flies and appears under the guise of a pair of filaments called "poisers," or "halteres." This would seem to show that once 
upon a time the fly-race possessed all four wings. How and why the hinder wings disappeared is more, I believe, than any one can venture to say.

As for flight, it is tolerably clear the insect contrives its aërial movements with excellent skill. Indeed, if we appeal to M. Marey, of Paris, as an authority on animal locomotion, we learn that our fly, when held captive, moves its wings 330 times a second. Now, this is a really high rate of speed when com-

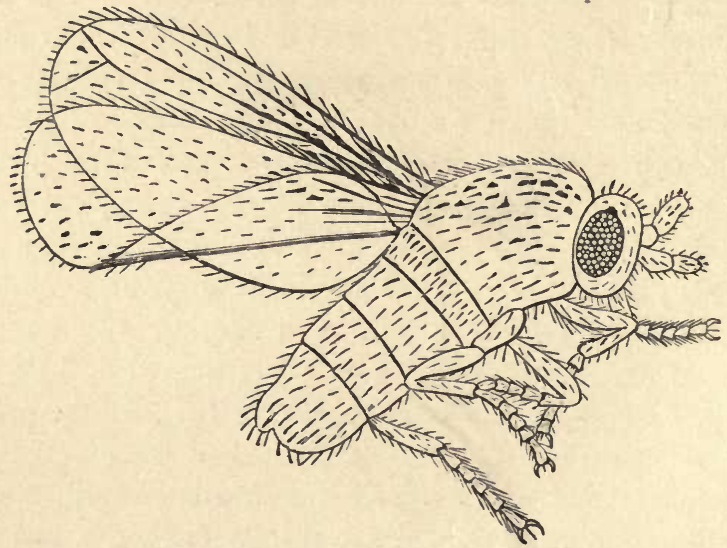

Fig. 32. -The Common House-fly (enlarged).

pared with the rate of movement of the honey-bee at Igo times a second; and it throws the butterfly (only nine times a second) into the shade altogether.

So also Landois has studied for us the music of a fly's wings. Every one knows the difference between the droning and the sharp "buzz" of a fly. Taking the correspondence of the sounds made by the insect with musical notes, Landois tells us that a fly which produces the note $F$ moves its wings 352 times a second; a bee making the sound of $\mathrm{A}$ 
vibrates the wings 440 times. A tired bee hums on $\mathrm{E}$, and vibrates some 330 times in the second. The bee's contented hum, when in quest of honey, is A. Thus there is really an expression of the emotions in these insects; and there is no better reason, after all, why a fly or a bee should not give vent to its joy or indicate its rage, than our neighbour the Gaul should shrug his shoulders or turn out the palms of his hands.

After a busy season, the flies leave the soul of the housewife vexed and angry. She contemplates with dismay the fly-blown paper, and the scratched and eroded surfaces of her furniture and books. If it is desired that the source of these destructive powers should be seen, you have only to put the fly's tongue under a low power of the microscope. This is the organ which, when at rest, is bent up beneath the insect's head. When it alights on the sugar, you can see the fly unfold its proboscis for predatory purposes, and scrape the toothsome morsel. The end of the tongue actually unfolds into a couple of broad fanlike leaves, serving at once as raspers and suckers. By means of this rough file-like expansion of the tongue, the fly works havoc with delicate surfaces, and it is doubtless this proboscis which annoys and tickles us when the insect pays those personal attentions to which allusion has been made. The fact of the tongue being an unruly member and a source of annoyance finds a new interpretation in the case of the fly.

Like the butterflies and beetles, the fly passes in its development through what zoologists call a perfect metamorphosis. In other words, it begins life as a grub or caterpillar - the baby flies are scornfully denominated "maggots" - then it becomes a pupa or chrysalis, and finally einerges into the full-grown and winged insect. 
As a maggot it is active, while as a chrysalis it is quiescent-this, in short, is the characteristic feature * of the perfect development.

There is, however, much more in fly-development than meets the eye of the popular naturalist. Ordinarily, or at least in many insects, the organs and parts of the grub are gradually transformed into those of the adult. Long ago, Newport taught us how the caterpillar's long and diffused nerve-chain grew into the much more concentrated nervous system of the butterfly. The flies, however, seem to illustrate a metamorphosis which is much more complete and sweeping than that just indicated. When the maggot, white and legless, leaves the egg of the mother-fly, there are found within its body certain curious masses, arranged with tolerable regularity, and called imaginal discs. So long as the maggot stage continues, these discs remain in statu quo. The grub eats voraciously, changes its skin to accommodate the increasing growth of its body, and finally, after thus laying up a store of material in which development is to work its own sweet will, it becomes the chrysalis.

Then these discs come to the front of things. They enlarge, and out of their substance are formed legs, wings, head, proboscis, and, in short, the belongings of the adult fly. The organs which served the maggot disappear and dissolve away, and only the tail of the grub seems to take part in the formation of that of the full-grown insect. This study makes it clear once again that the fly is an insect with a history. It has come to be the fly of to-day, as the result of a very ancient process of evolution; and although this fact may not reconcile us to its worrying habits, it may perchance invest our enemy with a new interest in our eyes. 


\section{XXIX.}

\section{$\mathfrak{A} \mathfrak{G 0 0 0}$ Starve.}

THERE is a bit of popular physiology and folk-medicine which asserts that "a good starve" is a simple and effective means of treating not a few of the ailments to which flesh is heir. One very admirable feature of this remedy, and one which is certain to commend itself to many frugal minds, is its entirely cheap and inexpensive nature. I suspect that, like most really good and simple means of treating disease, however, the "good starve" will not attract devotees by reason of this very quality. of cheapness, and because it is, perchance, a relatively unpleasant process when all is said and done.

Nature abhors a vacuum - and, I will add, especially human nature. Starvation, or, to put it more mildly, abstinence from food for any length of time, is not an agreeable phase of life. If there is (as there should be) a fair amount of enjoyment in the healthy appreciation of the good things of this life, it is tolerably certain we cannot be justly regarded either as Philistines or Malignants, because we hear with agreeable delight the joyful sound of the dinner Bell or gong.

But just as there is a philosophy of dining-and moreover a philosophy of dining well-so it may turn out that "a good starve" has likewise an intellectual 
backing. It will never be a popular practice : of that let us all rest well assured. Like many other excellent things in the way of remedies-to wit, Gregory's farfamed powder, or even the bland and emollient oil of cod itself - the virtues of starvation are not to be measured by its purely physical characteristics.

One may rest in a tolerable sense of logical security after reiterating the assertion that the vast majority of us eat far too much. Amid the crowd of fads and "isms" with which we are deluged by would-be reformers in these latter days, there is scarcely a solitary voice which lifts up its accents to declare that we are given to gluttony in a physiological sense, or to extol the merits of frugal fare. Yet Nature herself preaches us many a sermon on that same text. When we are indisposed she does away with the appetite as sharply as the Water Company cuts off the supply when the householder is far behind with his rate. The starve we feel to be necessary under such circumstances, is really but another name for the physiological rest of the organs we have overtaxed.

Persons "with a liver," as the phrase goes, know only too well how, under a starvation régime, they recover their tone; and your gouty man, and his plethoric neighbour, are each similarly made to see that life is worth living after experiencing the benefits of a starve, and after giving the internal mechanism a necessary rest. Then, again, certain of our neighbours exemplify starvation, as related (under the name of "Fasts") to religious observances. The Jewish fasts are well-known institutions, and there are those who do not hesitate to attribute much of the energy and vitality of that ancient people to the regular exercise of abstinence from food at fixed periods. I have 
heard a High Church clergyman enunciate the same opinion as an argument in favour of Lenten fasting; and (as a physiologist), I confess I am in thorough agreement with such opinions.

If so much socially may be said for a good starve now and then as a kind of hygienic rite, the question arises, What is the scientific side of abstinence from food? There can, of course, be no such thing possible as total abstinence from "food" for any length of time without a fatal result accruing. By food, however, let us see what one means. There is, first of all, air-food, the oxygen we breathe into our lungs; then comes water, whereof two-thirds of our bodies by weight are composed. Next we want so much nitrogenous food; and so much starch and sugar and fat and oil per day, all of which things are non-nitrogenous in character.

Finally, we must throw in an ounce or two per diem of the necessary minerals-iron for blood, lime for bones, phosphorus for nerve and brain, along with soda and potash and other inorganic substances. Now, it is very evident that as regards item the first, namely, our oxygen, we cannot dispense with that commodity at all. It is absolutely necessary for the continuance of life, and fortunately it costs us nothing, and is not even included among the possible subjects of taxation by the Chancellor of the Exchequer, enterprising as he may be.

As regards the nitrogenous foods, the albumen and gelatine, and gluten and so forth, and the starches, sugars, and fats, and oils, we can gèt on fairly well without them for several days at least. At a pinch we might want them, without of necessity landing in the undertaker's hands, for a longer period still. The 
minerals, save, perhaps, our salt, we usually get mixed up with our other foods. But as for waterwell, it is exactly the one food without which (leaving air out of consideration) we cannot attempt to exist for any period worth naming. The evidence on which this assertion is based is very complete in its character.

Not merely do we know of shipwrecked sailors and entombed miners subsisting on water alone for somewhat extensive periods, and feeling relatively well when rescued, but we know of cases of harmless lunatics suffering from delusions who have starved themselves in secret, and who have lived on water solely for thirty, forty, or even fifty days. One may safely assert that all living nature participates in this demand for water as the essential food, leaving the all-surrounding air out of count for the moment. For, to the plants in the window, dryness is a fatal condition; and even the biggest tree succumbs when a long drought sets in, and no moisture gains access to its tissues. There may be abstinence, total or otherwise, from all other kinds of food (save air), but without water we are literally "nowhere," as the schoolboy puts it. It is the staff of life much more truly than the product of the baker's shop. In this light, then, water takes the first rank as a food; it is certainly the sheet-anchor of a "good starve."

If one endeavours to subsist without food and water, life will come to an end, say, in from seven to eight days. But if one elected to live on water (and air), and obtained a plentiful supply of both commodities, he might live on, as we have sccn, starved and meagre, and growing anything but "beautifully less" hour by hour, for thirty, forty, or even fifty days. This much was known long before the Tanners, 
the Succis, and others of that iik began to exhibit themselves as paying examples of the "Great Starve."

The reason why water of all foods will preserve life in the absence of every other form of nutriment has been already given. We are composed largely of water; it enters into every tissue; and it is needed for the performance of every act of life. Hence water asserting its importance thuswise in the body, comes, with air, to rank as the paramount food. Clearly, then, our good starve must mean and imply plenty of water and plenty of air. The other foods may for a time vanish away. The water will not supply the waste of the body, nor will it prevent the body feeding upon itself; but it will keep us going at low pressure, and in the absence of all food, ordinarily so called, will sustain us for many days.

Water, then, is our great hope and succour in the "good starve;" and it may be well to bear this fact in mind if we contemplate at any time enjoying the unusual luxury of experiencing a relief from the onerous duty of finding out something fresh for the menu. 


\section{1}

\section{$\mathrm{XXX}$.}

\section{Otber জenses tban Ours.}

My Dalmatian dog, "Spotty," has been considerably agitated in mind this morning over the appearance of a strange cat in my back garden. Albeit he is not on particularly friendly terms with the two feline members of the household, "Spotty" yet contrives to bear and forbear where the cats proper to his home are concerned. The mother-cat is somewhat given to a spitefulness of disposition towards her Dalmatian co-tenant, and her black son, the "Professor," treats the dog with high-handed contempt. But, as things are, life rubs on easily enough where the canine and feline units are concerned.

A stray cat, however, appearing within his own and special domain, causes "Spotty" a world of anxiety. He longs to be up and doing in the way of battle, and his voice rings loud and deep when, secure on the broken glass-bottles of the garden-wall, the strange cat contemplates his attitude and hears his loud vociferations with equanimity, or with something which goes as nearly as is possible to expressing a feline smile of contempt.

"Spotty's" anxieties, however, are not limited to this barking at the cats which perpetually leap to and fro "over the garden wall." When not a cat is to be 
beheld, and when there is not a vestige of a feline within a mile of him, I can tell of his latent animosity to the cat-tribe being aroused by his sniffing the ground, by his low growls and sharp yelps, and by the bristling of his back hair as his vivid imagination depicts before his mind's eye the possibility of the fray.

This sniffing and smelling of dogs which hunt their prey like my Dalmatian by aid of their noses, opens up a curious study in animal senses, and one which leads us towards many unsolved problems of life and brain. In the first place, what is it that my dog perceives? What is it that arouses his brain and muscle, through the medium of his sense of smell ? A cat passes with a light tread over the ground. Allow, if we will, that there is a characteristic odour pertaining to the cat-body-and to all other carnivorous animals, indeed-and the problem does not become simplified even after such an admission. What is there in the odour which remains to mark to my dog's intelligence and perception each light footfall of the cat in the back garden? What is the nature of the scent of the hunter which the wind carries to the wary deer, or to the lion or rhinoceros itself? What is the exact cause of the power which enables the vulture to scent the prey from afar off, or which tells the eagles where the carcase lies for attack?

Let us try to argue this matter out as best we may. The senses of an animal are its "gateways of knowledge." The eye sees not, neither does the ear hear. They are merely instruments - " receiving offices," to put it plainly - which transmit to the brain the impressions of the outer world, which modify, parcel out, and assort these impressions, and adapt them for being understood and appreciated by the seeing-centres and 
hearing-centres of the organ of mind. So much is matter of ordinary physiological teaching. And what of the impressions which fall upon eye and ear, nose and tongue, and skin?

Everything in the way of sense, as Goethe put it long ago, resolves itself into a matter of touch. Every other sense is a modification of touch; or, as it was originally put, "touch is the mother of all the senses." When we touch any object, that, of course, is ordinary sensation, pure and simple. It is the contact of the nerve-ends with the outer world, with which our nervous system brings us into relation. When we taste there is contact - that is to say, "touch "-of the substance to be tasted with the nerves of tongue and palate. When we smell there must be contact of nerve-ends again, with the odorous particles. When we hear and see, there is the impinging of waves of sound and of waves of light upon ear-drum and retina (the nerve-network of the eye) respectively.

Ethereal and delicate must ear-touch and eye-touch be, yet it is a contact of something material from the outside world with something material in eye and ear nevertheless. All our sensations and impressions, then, are reduced to the level of touch. It is only a question of the degree of fineness of the touch which awaits the comprehension of science whenever senses and their methods are discussed at all.

But certain clear facts lead us nigh to the comprehension of "Spotty," and his perception of cat presence, as well as to the understanding of the powers of the bloodhound in tracking the criminal, or of those of the St. Bernard in finding the frozen man beneath the snow.

It is provable, first of all, that any form of matter 
which possesses a smell at all, exhibits that property in virtue of its power of giving off fine particles of its substance. It is similarly clear that the odour of any body will be the more powerful according as its particles are freely given off. Take the case of musk, for instance. We weigh a grain of musk in a chemical balance which turns the scale with the merest fraction of a grain. Thuswise, we secure exact weight, and we place our grain weight of musk in a room. For years, our grain of musk will appreciably scent that apartment. During all this period it must, therefore, have been giving off its particles to the air ; yet, mark the astourding result -if we weigh it years afterwards, we shall find it show exactly the weight it originally possessed.

Plainly, then, the particles given off from the musk in such numbers must have been of such microscopic size as to leave practically unaffected the bulk of the substance. Our minds fail to grasp any idea of the size of such particles. Sir William Thomson's estimate of the size of atoms may find a parallel in the particles of our musk; yet, small as these particles are, you observe they excite the sense of smell, and become appreciated by our brain as those of a wellknown perfume. It may interest us to know that Sir William Thomson makes the ultimate atoms of matter each measure, in diameter, the one-fifty-millionth part of an inch.

As far as sight is concerned, I believe Helmholtz gives a particle which is the eighty-thousandth part of an inch in diameter, as the smallest which can be distinctly made out by the eyes in association with other particles. Such estimates of what matter is, microscopically regarded, may serve to teach us some- 
thing of the acute nature of the sense of smell in man, relatively to our particles of musk.

But that the dog's sense of smell is infinitely more delicate than our own is evident. Your collie tracks out your footsteps by the odour they have given off amidst a dense crowd of people. "Spotty" recognises the tread of the cat by reason of the fine particles which the feline impression has left behind it, and which appeal to his nerves of smell while all unrecognised by us. The bloodhound, in the same way, with keen scent, traces out the resemblance in smell between the footsteps of the criminal and those of the garment which belonged to the evildoer.

The dog's brain shows large lobes of smell, and big nerves emanating therefrom. His nervous apparatus in this respect makes for him a world of odours all unappreciated by his master. As there are many other worlds than our own whirling round in the blue ether, so in truth, in lower life, there are many other more powerful and more acute senses than ours. 


\section{XXXI.}

\section{Fometbing lliew about the Ear.}

IF one were asked to select any portion of man's wonderful frame which is more wondrous and more complex than another, I should advise the candidate for honours in elementary anatomy to choose the ear. For, unquestionably, the ear is more complex than the eye-probably more intricate, indeed, than any other of our sense-organs. To begin with, there is the outer ear, which is in itself worth some study, as Darwin has shown us, in respect of its conformation. The passage or canal of the ear (fig. 33, 2) passes inwards, and is blocked, like a cul de sac, by the drummembrane or tympanum. This membrane receives the waves of sound and transmits these vibrations to the internal ear, which is enclosed within the temporal bone. Now, it is this internal ear which is of such marvellous structure and of such intricacy. Let us try to think of its various parts for a moment or two. On the inner side of the "drum" (fig. 33, 2 ') a tube (called the "Eustachian tube" (fig. 33, 4), after an old anatomist) leads into the throat. This arrangement evidently serves to ensure equality of air pressure on each side of the drum, whatever else may be its use. Between the brain and the drum is a bony partition, bearing two apertures. One of these is oval in shape, 
and the other of rounded outline. The next part of the ear consists of a chain of three small bones or "ossicles" (see between 3 and 6, fig. 33), which lie across the drum in such fashion that all vibrations of that membrane must, of necessity, be communicated to the bones. One bone is like a hammer in shape,

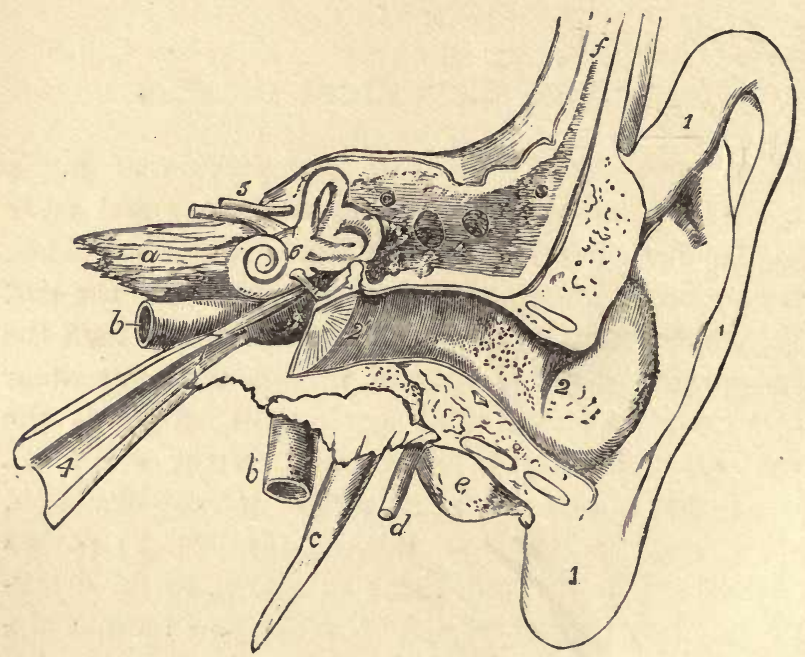

Fig. 33.-View of the parts of the ear from the left side. r, outer ear ; 2, external opening and ear passage; 2', drum-membrane; 3 , cavity of the tympanum; between 3 and 6 , the chain of small bones; 4 , Eustachian tube ; 5 , facial and auditory nerves; 6 , internal ear; $b$, internal carotid artery; $d$, facial nerve; $a, c, e, f$, portions of bone.

the second like an anvil, and the third like a stirrup. The flattened plate of the stirrup-bone is placed on the oval opening in the bony partition already named. The next part of the ear is the labyrinth, which contains fluid, and which receives the ends of the nerves of hearing whose mission it is to carry the messages they receive from the outer world to the brain.

The labyrinth itself is composed of two parts. Of 
these, the first is the cochlea (fig. 34, coc.), which .resembles the shell of the snail somewhat in appearance; while the second is constituted by three curious semicircular canals (S C). Inside the cochlea is a very wonderful structure, called, after its discoverer, the organ of Corti. This is really a microscopical sounding-board, or something more complex still. It consists of about 4000 minute rods or arches, which are graduated in length and height as we pass from the top to the bottom of the snail-shell. Each arch or rod vibrates in unison with a particular sound-wave, and from their action we are supposed to gain notions of tone. Helmholtz tells us that the rods of Corti correspond to the seven octaves which are in common use ; and this fact, with others, seems to teach us that, as a tone-indicator, the organ of Corti plays its part very well by us in our appreciation of sounds and their pitch.

Of the semicircular canals of the ear and their uses or duties, we have hitherto not been quite so well informed. Of yore, it was believed that they gave us a power of estimating the direction of sounds, and, until lately, we had to be content with this assertion. Now, however, we have come into possession of fresh facts regarding these canals and their uses, and this brief recital of the anatomy of the ear and its parts has been intended by me simply as an introduction to a little bit of tolerably recent science-or rather of scientific discovery now elevated into the rank of accepted fact. As early as 1824 , Flourens, the great physiologist, in experimenting upon these canals - which, by the way, are placed in three planes at right angles to one another - suggested that they might prove to be the organs of a sense of novel and hitherto unknown nature; and 
Professors Crum Brown and Mach have succeeded in confirming this opinion, and, what is more to the point, in elevating it into the region of certified facts.

As the former scientist lately remarked in the course of a public lecture, we really possess little or no means of judging of motion. We move through space in this old world of ours at the rate of 68,000 miles per hour, yet we are all unconscious of the movement. The rapid, even motion of a train may be really

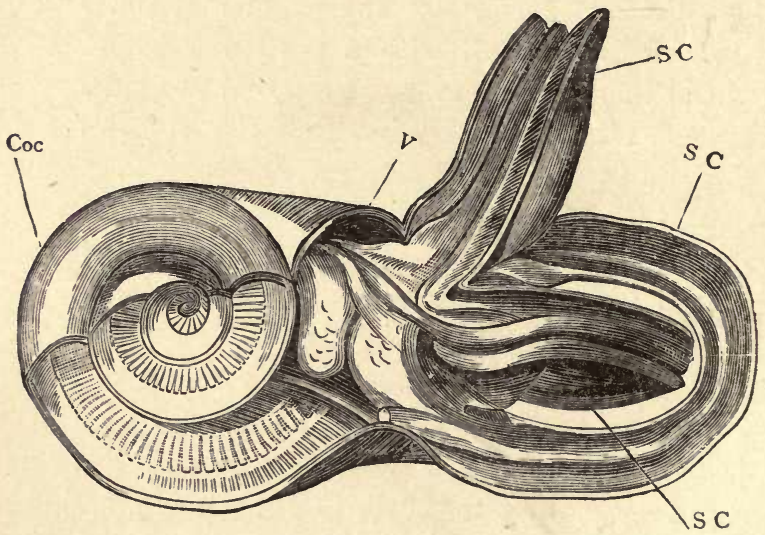

Fig. 34.-The Inner Ear.

Coc., Cochlea ; V, vestibule; S C, semicircular canals, laid open.

unperceived, and of many other circumstances relating to movement the like remark holds good. Yet, any deviation of motion from the straight line is at once perceived-how or why is the puzzle; but at least we are conscious of the transition, say, to a curve or to a steep gradient.

It is the same, as has well been pointed out, with the ascent in a lift or in a balloon. At first we seem to be going down, but midway in the lift we become unconscious of the movement, until the apparatus 
comes to a stop. Experiment helps us here. A revolving table is constructed as in Mach's experiments, and this is placed in a hut on whose paper-blinded windows no changing lights or shadows are allowed to impinge: or the subject may be simply blindfolded.

Lying on this table on his side and comfortably resting with his head on a pillow, the person is whirled rapidly round by the rotation of the table. At first he is conscious of the motion, but in a moment this sensation disappears, and, if the table whirls on at a given steady pace, all sensation of movement continues to be absent. Let the rate of rotation, however, be altered, or let the table come to a standstill, and the consciousness of motion once more wakens into activity. Some means or other we must and do possess, therefore, for enabling us to determine this alteration of speed.

As our friend lies on the table placidly on one side, consciousness of motion is absent. When, however, the subject is placed on his back, or when he turns of his own accord suddenly, he feels as though the table had stood straight up, and as if he were being shot headlong into some vast abyss. Here, it is evident, consciousness and reason itself, of which consciousness is the servant and minister, are evidently much at fault ; for the person is lying flat and safe on his back, after all.

Next comes a little hint from that experimenter on our bodies we name "disease." There is an ailment called "Menière's disease," which, first described in I86I, shows as its symptoms giddiness, a staggering walk, with a tendency to fall on one side, and deafness on one or both sides of the head. Examination of the ear in such cases seems to show that the seat 
of the ailment resides in the semicircular canals we have been discussing. A study of disease, therefore, tends to confirm what experiment suggests; and the conclusion we arrive at is that the canals in question, formerly regarded as part and parcel of the hearingsense, are really the organs of a new sense-that of motion. They give us information about the nature of the rotations of the head, and it is quite possible their sphere of usefulness extends even beyond this limit.

We see in these curious canals tubes which contain fluid - a condition suggestive enough, in a common way, of an apparatus to record changes of level. This fluid acts against delicate hairs when rotation occurs, and probably in this way communicates to the nerves of the canals an impulse which, in the brain, becomes translated into a sensation of motion. The turning of the head to right and left seems a small thing indeed, viewed from the ordinary standpoint. But if what has here been recorded is correct, it is obvious our knowledge of how far and in what direction we have made that movement is due to these curious canals of the ear. They are organs of sense which minister to our safe conduct as we move through space, and as we pass sorrowing or rejoicing through the world's pastures. 


\section{XXXII.}

\section{觡oise.}

I WONDER if it has ever occurred to any of my readers that this "fine old world of ours" would be a very much improved planet if its noises were reduced to a minimum, or, mayhap, abolished altogether. Personally, I have often been given to lament the noise and clamour of life; and the topic of noise, in relation to our peace, comfort, and health, has been forced upon my attention of late in more ways than one. A recent Continental tour has impressed me very forcibly with the fact that hotel-keepers might do a worse thing (in the way of business) than advertise (and ensure) that their caravanserais are quiet and free from the clamour and din which beset these establishments as a rule.

What is true of foreign hotels is equally true of English ones, and, one may add, of not a few of our homes as well. We really suffer from noise much more acutely and severely than we suppose. Later on, I will recur to the physiological side of this social nuisance, but it is easy enough to indict it, on plain grounds, in the first instance. At Scheveningen, for instance, I inhabited a room which, unfortunately for me, looked out on the street that leads from the town to the beach. When the fishing-boats arrive, carts trundle up and down this street all night long. You 
dropped off to sleep, but were soon awoke by the roll and thunder of the carts over the stones. Then succeeded a pause of, say, fifteen minutes, just sufficient to allow you to fall off to sleep again.

Out of this slumber you were awoke by the next cart; and so on, this wretched succession of noise and peace persisted for at least six hours. Commend me to a night which is disturbed at regular intervals for causing one to rise ill-tempered and haggard in the morning. After two nights of this treatment one began to appreciate the infernal ingenuity of the Chinese torture, which consists in waking a man every five or ten minutes for days and nights on end.

Nor was this all. A big, brawny Dutchman, wearing Wellington boots, was in the habit of strolling upstairs to bed about midnight. When one was in the "beautysleep," this adipose Hollander would first of all halfwake me with his Jumbo-like tramp upstairs. Then when he got overhead, he slammed his door with a noise fit to wake the Seven Sleepers; and thereafter began a series of pedestrian exercises in his bedroom, ending with a perfect salvo of artillery made by casting off his Wellington boots, flinging them outside his door half-way along the passage, and slamming the door once again as a grand finale to his preparations for slumber.

This is a grievance one has to submit to in England, of course, but it is a grievance all the same. The hotel servants in the morning laughed and chattered, and made noise enough in the passages; and, finally, when it was time for the morning dip in the sea, you felt disposed to turn over, and through sheer exhaustion take not forty but a hundred winks. The fact is, that both at home and abroad we are not a: 
all particular regarding noise, and we suffer therefrom to a degree that tells on health, spirits, and temper in marked fashion.

Londoners and denizens of other towns know what it is to be disturbed by the lively Chanticleer who heralds the dawn, or by dogs which "bay the moon," and often apparently bark at other planets as well. There is not the least attempt, as a rule, in social life to repress this noise nuisance; yet, without in any sense being deemed querulous or fidgety, we may demand that for health's sake people should begin to protest as forcibly against the din and clamour of life as they do against the attempt at extortion which appears in their hotel bills under the head of "attendance."

Let us consider what noise means scientifically to the living body. Every sound we hear is first of all conveyed to the drum of the ear, which, in its turn, sets in motion sundry small bones that affect the internal mechanism of the organ of hearing. The sound is then parcelled out, as we have already learned, into its component elements of tone, timbre or pitch, direction, and so forth, and is finally transferred to the hearing-centre of the brain. This centre discharges the final work of appreciating the nature of the sound and of converting it into an intellectual item in our consciousness. That we really hear with the brain, is therefore a truism of science, just as we see with the brain, and taste, smell, and touch with the organ of mind.

Our senses are the mere receiving offices of the nervous system. It is the head-office or brain which ultimately deals with all the messages or sensations that reach it from the outer world. Now a noise, which differs from a musical sound in the irregularity 
of its vibrations, as may readily be conceived, affects not the ear alone, but the brain likewise. That its effects are irritating enough on the ear may go without saying. That the brain must sympathise with its receiving offices is obvious, and in this respect noise is a nervous irritant, the effects of which probably inflict a greater amount of injury than is usually supposed. We see how the opposite condition to a real noise may affect the nervous system, in the effects of the monotonous sound which causes us to drop off to sleep. Here a kind of mesmeric influence is exerted by the sound, just as a bright light will induce sleep in time. Each organ of sense is, in fact, wearied out by the number and frequency of the impressions made upon it, and a sense of fatigue, with a tendency to slumber, is the clear result.

The abolition of noise in social life, I am convinced, would mean a vast improvement in the health, temper, spirits, and general welfare of everybody. I do not wish to imply that life could be carried on without sound. The dead dulness of a forest at noonday is in itself depressing. Life, meaning, as it does, action and motion, is inseparable from sound, but sound is not necessarily noise; and, while we object to the latter, it is very obvious we could not reasonably disagree with the former, including, as it does, the existence of music itself.

Suppose, for instance, that, in place of the hard causeway of our streets, wood or asphalt-paving became universal, what a wondrous diminution of noise we should find. Or, if the habit of placing indiarubber tyres on the wheels of our vehicles became a common practice, how greatly would our comfort in locomotion be increased. If, in addition to 
these things, we could ensure that in our homes the noise of life were reduced, by the exercise of a very little care, to a minimum, I warrant our health, as affected by our nerves, would be less subject to derangement than is the case to-day.

It seems an almost trivial thing to attach so much importance to noise as a factor in making us both irritable and nervous; but we are perpetually admitting the fact by our tacit abhorrence of noise, whether in the rattling of omnibus-windows (a particularly irritating form of noise) or in the grumble at the heavy feet of the "early bird," who rises betimes, and takes care that everybody within hail of him shall become well and instantly acquainted with the fact.

I may go the length of suggesting that our annual holiday and country flight has the theoretical absence of noise as one but often an unrecognised reason for its continuance. We leave the bustling city with its roar and din for the quiet peaceful country-life, and the absence of noise is a condition which operates beneficially, like all other forms of rest, on our wearied and jaded nerves. But woe betide us if, leaving the city, we only run into new combinations of noise. We begin to envy Thoreau in Walden Wood, when we think of the peace and quiet that quaint zoophilist enjoyed as he made friends with the birds and beasts, and heard only the sweet sounds of forest-life in place of the roar of civilisation. 


\section{XXXIII.}

\section{The Troblem of $\mathfrak{L i f e .}$}

THE air has been tolerably full, of late, of echoes and re-echoes of a very antiquated question-namely, that which inquires whether life is worth living. If one may judge of the importance of an inquiry by its age, this question may almost claim precedence of all other matters which have interested mankind. There is something highly interesting to the scientific mind, I think, in such a controversy; because, first of all, it seems to me the problem of life being worth living must be solved, and can be solved only by the aid of science.

Then, also, it becomes clear that public thought is by no means quite so selfish an affair as we are often tempted to believe. We are having the question, "Is Life Worth Living?" discussed by the people, as I write; and that folks should spare time to indite thcir views and opinions on such a matter, in this bustling age, is truly a sign of the times from which one might argue that disinterestedness and unselfishness are not, after all, either unknown or unpractised in modern life.

Yet throughout the controversy or symposium, as it might better be termed (I have read the contributions of wisdom and experience with care, as a pleasant exercise on a Continental holiday), one misses a 
practical ring in the guidance which most of the writers have to give in this matter of living wisely and living well. It seems perfectly clear that many of the scribes who discuss that topic in the papers require a guiding clue to close argument. They become discursive and often aggravating in their discussion of the thousand and one ills of life, until, as I heard a peppery old Anglo-Indian remark at Dinant the other day, "life would be worth living, if it weren't for the asses who write to the papers!" This was not a fair or just remark, however, and judging from the physique of the critic, one may presume that years of broiling beneath a tropical sun may have tinged his view of life and its value in a very decided fashion.

The first essential to a pleasurable life, in my humble opinion, is a sound body. Let us, at least, begin with this plain dictum. It offers us a sound footing in a perfect quagmire of absurdities and trivial talk about the aims and ends of life.

What was it that Charles Reade made that delightful Dr. Sampson (“th' Author an' Invintor of th' Great Chronothairmal Therey o' Midicine, th' Unity Perriodicity an' Remittency of all disease") say, when he was dilating on the value of life_- "Jin'yus! Jin'yus! Tak' care o' your carkus!" ? There was great, very great, wisdom in the worthy doctor's remark. The possession of perfect health is the first great essential for happiness: it is equally the first essential for the perfect exercise of mind; and it therefore forms the first item for our consideration when we ask the question, Is life worth living? To the healthy man or woman who takes care of his or her "carkus" all things in the way of advance and enjoyment, physical and mental, are possible. 
Conversely, with a body weakened, no matter how or why, most things become impossible, or, if not actually unattainable, they are at least achieved with difficulty and through pain and tribulation of spirit. Sound health is the first condition for enjoying life; and, if we reflect upon the common causes of life's failure in a social sense, we may easily prove that much of the want of success is due to sheer physical incapacity to enjoy existence. This incapacity, again, largely arises from the lack of knowledge about health and its laws.

I may be pardoned for laying stress on this ignorance, because I happen to be very practically associated with a certain work and labour of diffusing such knowledge broadcast, and because I know how much work yet lies ready to the hand of the reformer in things sanitary. With thousands of units around and about us, possessing weakened bodies and living under conditions the reverse of sanitary and the antipodes of cleanliness, freshness, and brightness ; and furthermore, with the clear and plain fact that such bodily weaknesses are perpetuated onwards in increasing force from one generation to the next, who can wonder that life is decidedly not worth living or worth having at the cheapest rate? Do we need to go much further than this very primary matter of health as an allsufficient cause for failure in most of the things, aims, and aspirations which make up the Life Beautiful?

This, then, is my first contention. But there are other points which deserve and demand consideration at the hands of those who discuss the question at issue. When the poet longs for the "simpler life," and for the fuller existence, he is expressing a very real and crying desire which many an earnest mind among us feels 
very strongly and really in these latter days. Our age has been described as an intensely artificial one, and one must admit the grave truth of the assertion. Social advance, it is said, has made us all more luxurious in our living than was the case even a quarter of a century or so gone by, and that the statement cannot be gainsaid is obvious.

People nowadays are not contented with the comparatively plain ways and works of their forefathers. There is a desire, widely represented, "that the nobodies among us should all be somebodies," as a writer graphically puts it; and, in the struggle to evolve a social order which shall eclipse all preceding states, luxury and extravagance come to the front, and alter the ways of life, and that very much for the worse. If any one of us chooses to appeal to his own experience, he may easily discover that, in countless ways, in the matter of foods and drinks, clothing, amusements, and so forth, he is tempted in a thousand directions towards needless luxury as against healthier simplicity.

This tendency must operate, I fancy, in producing discontent in the case of thousands ; and life, therefore, seems to fall short of satisfaction, just because our ideas of what constitutes happiness and comfort have become themselves essentially of an impossible type. It may be that this striving after wealth and distinction is, in its way, by no means a bad thing after all. What one sees is, that we have to pay a certain penalty when we enter upon a course of life of this kind, in respect of the dissatisfaction which is sure to ensue when we have to content ourselves with the lower place instead of the so-called higher station. If our teachers will only preach at us and to us about the simplification of 
life, I can imagine they will have at least secured a very pregnant text for their admonitions. My AngloIndian acquaintance put it pungently enough when he said of this matter that "they've begun to simplify our funerals; but, by Jove, Sir! that's tackling the question at the wrong end."

It is plain enough that there is no panacea for the ills and disappointments to which life is subject. The treatment, to use a medical term, is only palliative, not radical. One cannot lay down laws and precepts which can make every man and woman happy. Out of Utopia itself there could not exist such a condition as that of universal satisfaction with everybody and everything. But humanity has had sufficient experience of life and living, nevertheless, to make it clear and plain that certain broad rules of conduct carry in their practice the basis of the true answer to the question, "Is Life Worth Living?" To be honest and true and upright, let us hope, will never become an old-fashioned order. If to these things one adds that we must be healthy as a primary condition of life, we may find, with Dr. Sampson, that following closely on the care of the "carkus" is a whole host of other ways and means of enjoying existence in fairly full measure. 


\section{XXXIV.}

\section{Wabat is sidesmerism?}

THE air of late years has been full of discussions respecting mesmerism and its use in medical practice -or, what is much the same thing, its applicability to the wants of social life when that life has to be ministered to for the relief of the ailments which beset it.

In these latter days, mesmerism is no longer known under that name. It is now designated "hypnotism," and, as such, figures boldly both in the medical journals and in lay newspapers. Some time ago, I became personally interested in the subject, and consented, at the request of my friend Dr. Bramwell, of Goole, to initiate a discussion on the question of mesmerism in medicine in Health, the journal I have the honour to conduct.

That symposium has proved to be of great interest; because a large number of eminent medical men have contributed to it, and because of the variation in opinions which the symposium has been the means of eliciting. A remark of mine has also been quoted in the New Review, in an article by Dr. Bramwell and Mr. Lloyd Best, his collaborateur, and has been criticised adversely by these gentlemen. Now that Sir Andrew Clark and others have delivered their opinions on hypnotism, we are certainly free to discuss the matter everywhere, for it is clear that the question whether, 
as a nation, we are to permit ourselves to be hypnotised, will only be thoroughly settled by our first of all understanding what hypnotism is, and what it professes to do in the way of curing disease.

I made the remark that the mesmerist or hypnotiser could only be successful where there existed intellectual sensitiveness on the part of his subjects. My words were: "It is impossible to hypnotise every one; and, as far as my experience of it goes, only in the case of the intellectually sensitive-shall I add weak ? can hypnotism hope to secure its most characteristic effects." Dr. Bramwell and Mr. Lloyd Best, referring in the New Review to these words, state that Beaunis, a Continental authority, is "of the opinion that every one is more or less susceptible to hypnotic influence." They add that their own experience seems to confirm the views of Beaunis.

Now, one fact is worth many theories, and I maintain fearlessly that both Dr. Bramwell and Beaunis are in error. For, personally, although I have been many times tried by different hypnotisers, I have not been in the least degree affected. Again, I know others who are in a similar position to myself. They have not been mesmerised after repeated trials. Dissected out, Beaunis's statement, as recorded by Dr. Bramwell, is that every one is " more or less susceptible to hypnotic influence." This is a relative statement, after all. It includes comparative degrees, from success to the zero-point; and it does not logically, therefore, mean all its authors might evidently be regarded as implying.

To allege that everybody can be hypnotised is a rash assertion, and nothing more. For, to be true, it must include a full knowledge of every human being's 
mental constitution, and likewise of every hypnotiser's powers. Need one remark that neither Beaunis nor Dr. Bramwell nor Mr. Lloyd Best can (or will) pretend to such absolute knowledge? and, in the face of common-sense as well as of fact, I hold they are doing their cause injury when they expose it to an assault so easily made and so difficult to repel as that which even one's superficial examination of their statement suggests.

But "What is this hypnotism?" is a query the public are beginning to ask, and to which an answer must be afforded. I shall attempt a reply based on general grounds, such as, I trust, may be "understanded of the people." A human brain is composed of a series of nerve-centres, or parts regulating and controlling actions of more or less well-defined nature. It is not one organ, but a collection of organs, all working together, in the healthy organism, for the regulation of the life mental and the life physical as well. This much is certain and sure. While there is harmonious working, however, between the braincentres, there exists also a certain amount of independence among them.

Such independence is inseparable from the nature of the multifarious duties the brain-centres discharge. They may be compared to the sub-departments in a great Government affair-like the Post Office, for example-wherein each subdivision, while owning a central and connecting authority, exercises, on its own behalf, a fair share of responsibility for the discharge of its own duties. Now, roughly, yet correctly speaking, the brain shows a division into what we may term intellectual centres and lower or automatic ones. The former, located chiefly, or wholly, in the forehead lobes 
of the brain, deal with the highest affairs of the mental state. They exercise the will, they are the seats of intellectual operations, and they constitute by their collective working "the conscious Ego" which is the essence of our responsible individuality.

The lower or automatic centres, on the other hand, as their name implies, are in the position of self-acting machines. They control actions and operations which lie outside the will, and which are not (necessarily at least) associated with our consciousness. Reading and writing and walking, are each and all acts which are automatically regulated. We have to acquire them, it is true, but, once acquired, they are ever afterwards performed without thought. Over such acts, then, the lower brain-centres preside. I might quote the heart's action, the regulation of the blood-vessels, swallowing, and the movements of the stomach in digestion, as additional illustrations of automatic acts.

These lower centres of ours save us a vast deal of trouble and worry. They leave the intellect free to deal with deeper problems than are involved in the mere acts of living and being; and when we come to think of it we see that a good three-fourths of our lives are really composed of actions which are performed utterly without thinking, and which are all the better performed, in truth, because we have not to think about them at all.

In sleep-walking, we see how the lower centres of the brain can assume temporary command of the body, how they can rouse the sleeper from his bed, and direct and guide his movements unerringly in the majority of cases. Now, mesmerism, or hypnotism, is an analogous condition to somnambulism. I take it that in the hypnotic state, however induced, there 
is essentially the abolition of consciousness and will, by the repression for the time being of the intellectual centres. It is useless and needless to say how this occurs; it is sufficient to say it does occur. In one way or another, the hypnotiser succeeds in abolishing the intellectuality of his subject. The lower centres are stimulated and come to the front. Automatic life replaces the conscious existence; and the individual is, temporarily, as clay in the hands of the potter : he is made to think and act at the behest and command of the individual who has succeeded in reducing him to the level of a mere machine.

This is the essence of hypnotism. Sir Andrew Clark put the matter in other words when he said that the liability of any one to be mesmerised stood in inverse ratio to their intellectual development. If this means anything at all, it implies exactly what I meant when I declared that it is the intellectually sensitive (or weak) who are the hypnotiser's best subjects.

After this declaration, I have no more to say on the subject. If Dr. Bramwell or any other hypnotiser can persuade certain people that they are not ill, that pain has left them, and that they must be made unconscious while being operated upon, I have no concern whatever with his procedure. All I maintain is, that he will not, and cannot, succeed with people having a fair or complete share of volition and intellectual force.

Nor do I envy those who can be "mesmerised." As I have often expressed it, a person who is hypnotised is in the position (quâ his brain) of having the captain of the ship deposed from the quarterdeck, and the cabin-boy installed in the captain's place. And this is not an agreeable, safe, or healthy proceeding either on shipboard or in mental life. 


\section{XXXV.}

\section{Tbe Case of Colonel Townsbeno.}

Some time ago I was discussing with a friend the curious nature of certain human acts which are capable of being performed by only a limited number of individuals among us. The argument began by the information being afforded me that the friend in question could move his scalp backwards and forwards. This display of muscular power failed, of course, to arouse my enthusiasm. It is not unusual for a person to possess the power of moving or wrinkling the skin on the top of his head, so I contented myself with remarking on the tolerably common nature of my friend's performance.

When, however, he proceeded in Dundreary fashion "to wag his ear" my interest became aroused, and the discussion on unusual muscular movements in man was duly inaugurated. That my friend could at will "wag his ear" was not for a moment to be doubted. Seeing was believing-in this case, at least.

He reminded me of a still more typical case of such ear-movements which occurred when I was a University examiner. I had before me a student who was a decidedly nervous subject. Each question, propounded to him in the gentlest of fashions, threw him into a cold perspiration. Then came another revela- 
tion. When his excitement reached a certain pitch, his ears began to wag, and the dignity which is believed to hedge about an examiner was in high danger of giving place to a species of ribald mirth at the spectacle before me. Doubtless his movable ears saved that candidate from being "plucked;" for as I began to question him about his abnormality in the way of muscular movement he recovered his spirits and his confidence. He told me that sundry members of his family - past and present-exhibited the same peculiarity; and as he then proceeded to his further trials and questions he gained lost ground, and departed from the examining-table triumphant-his ears, as I thought, giving a parting twist of joy at the prospect of a "pass." Possibly, if my former candidate should read these lines (he may be a medical man in full practice by this time) he may realise how he was saved, in one of his examinations at least, "by his ears."

My friend's discussion opened up the wide question of the control which now and then man may be found to possess over parts and organs of his body which are usually involuntary in their nature and action. Certain of the ear-muscles, nose-muscles, and the scalp-muscles illustrate structures which, however movable they may be in lower life, are useless to man. A seal, for instance, closes its ears and nose when it dives, and its nuscles act perfectly to ensure the freedom of these parts from the inroad of water. But although man has representatives of like muscles in his ears and nose, they are to all intents and purposes inactive and inoperative.

If humanity ever used these muscles at all, it certainly has no use for them now. The law of disuse 
speedily reduces, to rudimentary dimensions and to an inoperative state, all organs whose activity becomes lessened or abolished. From the discussion of such human muscles and their past and gone functionsoccasionally surviving faintly as we have seen in scalp and ear-our talk led on to an explanation of more curious acts of man's life, in which a command over organs usually self-acting is sometimes illustrated.

For instance, I cited the occasional occurrence, in humanity, of the power of returning the contents of the stomach to the mouth, painlessly and at will, as an instance of such command. Here we see in man the establishment of a power which is entirely absent, as a rule, and which seems to represent part of the act of "rumination" or "chewing the cud" in lower animals. What oceurs in such cases is simply the development of command over the stomach and gullet muscles. The one essential condition for such an abnormal feature of life, is the alteration of the nervous supply of the parts concerned. That is to say, parts usually governed by the involuntary nervous system, come to be placed under the government of the voluntary nerves.

Now, a far more extraordinary instance of such command over parts of our bodies which usually work perfectly and harmoniously, apart from all intelligent guidance, was afforded by the case of Colonel Townshend. Some years ago I took the trouble to hunt up this case as given in its original form, and as contained in a queer old volume entitled "The English Malady : or a Treatise of Nervous Diseases of all Kinds, as Spleen, Vapours, Lowness of Spirits, Hypochondriacal and Hysterical Distemper, \&c. London : 1733." The author of this volume was one Dr. George Cheyne. 
He relates how Colonel Townshend, who was suffering from a known malady, came from Bristol to Bath in a litter, to drink the waters and to obtain Dr. Cheyne's advice.

He was attended by Dr. Cheyne, a Dr. Baynard, and Mr. Skrine; the last an apothecary, who always danced attendance on the physicians of those days. The Colonel informed his medical men of "an odd sensation he had for some time observed and felt in himself, which was that, composing himself, he could die or expire when he pleased, and yet by an effort, or somehow, he could come to life again-which it seems," says Dr. Cheyne, "he had sometimes tried before he had sent for us!" This statement naturally puzzled the doctors. Like wise men of science they could and did say nothing until they were well assured of the reality of what sounded like a physiological romance. Accordingly, the Colonel told them he was willing to make the experiment in their presence, and the following is Dr. Cheyne's account of what he and his comedicos saw :

The Colonel "composed himself on his back, and lay in a still posture some time; while I held his right hand, Dr. Baynard laid his hand on his heart, and Mr. Skrine held a clean looking-glass to his mouth. I found his pulse sink gradually, till at last I could not feel any, by the most exact and nice touch. Dr. Baynard could not feel the least motion in his heart, nor Mr. Skrine the least soil of breath on the bright mirror he held to his mouth; then each of us by turns examined his arm, heart, and breath, but could not, by the nicest scrutiny, discover the least symptom of life in him. We reasoned a long time about this odd appearance as well as we could, and all of us judging it 
inexplicable and unaccountable, and finding he still continued in that condition, we began to conclude that he had indeed carried the experiment too far, and, at last, were satisfied he was actually dead, and were just ready to leave him. This continued about half-anhour. By nine o'clock of the morning in autumn, as we were going away, we observed some motion about the body, and, upon examination, found his pulse and the motion of his heart gradually returning; he began to breathe gently and speak softly."

The sequel is instructive. After making his will, Colonel Townshend died the same evening about five or six o'clock, after having received the last offices of the Church. Dr. Cheyne leaves the case "to the philosophic reader to make what inferences he thinks fit;" and science to-day infers that Colonel Townshend's case was, one exemplifying nervous command over heart and lungs such as rarely occurs in human experience, and such as alters the way of life in a manner which is the puzzle of the wise among us. Nevertheless, there are obvious links between this case of command over the heart and that whereby we sometimes illustrate the power of wagging our ears. 


\section{XXXVI.}

\section{Tbe spleen.}

Who was it, of old, that first gave vent to the expression "a fit of the spleen"? And to whom, one may ask, are we indebted for the pleasing illusion that this harmless organ is a kind of cistern of all the vile humours which do congregate within the body's domain? Wordsworth, kindliest if also the moodiest of poets at times, speaks of the self-disparagement which "affords to meditative spleen a grateful feast." Pope's words, "parent of vapours and of female wit, who give th' hysteric or poetic fit," and his assertion that "The spleen is seldom felt where Flora reigns," evidently indicate a mixed opinion regarding this celebrated organ. More direct in his impeachment of the spleen is Green, who in his poem of that name advises us that "to cure the mind's wrong bias, spleen," we have to "fling but a stone," and "the giant dies."

The classic naturalists and physicians entertained curious ideas concerning this organ. To them it was certainly a vital puzzle. It did not seem to manufacture anything, as did the liver, and out of it there was no duct or pathway leading to the digestive system. Erasistratus, coming to the end of his intellectual tether in the matter, declared that the spleen had only the function of bodily "packing," in that it 
prevented the other organs being displaced when their possessor moved about. This was a sorry conclusion, no doubt; but then the spleen presented no ordinary problem to primitive physiology.

Listen to a quaint translation of what Pliny wrote about this organ: "This member hath a proprietie by itself sometimes to hinder a man's running: whereupon professed runners in the race that bee troubled with the splene have a devise to burn and waste it with a hot yron. And no marveile : for why? They say that the splene may be taken out of the bodie by way of incision, and yet the creature live neverthelesse; but if it be man or woman that is thus cut for the splene, hee or shee loseth their laughing by the meanes. For sure it is that intemperate laughers have always great splenes." Losing the "splene," according to Pliny, was thus " no joke," both in a literal and in an actual sense. So far he is right, however, in his statement that the spleen may be extirpated from animals (including man) without apparent ill-effect. This fact would only seem to justify the classic idea that the organ was of little or no use in the vital economy; but, as we shall see, there are other and better ways and fashions of explaining the anomaly.

It must be confessed that, as regards the spleen, there is not much to be told, structurally. Yet, from a basis of anatomical facts, we reach clear enough notions of what the spleen does. About five inches long by three or four inches broad, and, say, an inch in thickness and seven ounces in weight, the spleen is an organ of dark bluish-red colour, which lies, snugly enough, at the left side of the stomach. As I have noted, no tube or duct leads away from it - that is to say, it does not appear to be a manufacturing organ, 
like the liver or sweetbread, each of which has a given duty to perform in secreting a fluid (or fluids) from the blood, and of giving forth such manufactured products to be used in the digestive process. But, while there is an absence of apparent outlet, we are struck by the fact that into the spleen a very large artery passes, while out of it proceeds a very large vein.

- If, now, we subject the organ to a microscopic scrutiny, we learn more in detail regarding its nature. It is a soft pulpy organ, and its substance is appropriately enough known as "spleen pulp." This substance really consists of a kind of meshwork, supporting the softer matter of the organ. Now, into this pulp the artery of the spleen dives, dividing and branching, as it goes, into numberless minute blood-vessels. Closely connected with this arterial network are the beginnings of the splenic vein; so that, practically, we arrive at a first and important conclusion about the spleen, when we discover that blood must perpetually be whirled into the organ by the artery, and as constantly taken away from it by the vein.

We might, in truth, not inaptly compare the spleen to a kind of whirlpool or eddy, on the course of a river-the blood-circulation-into which the stream is swept, and out of which it is in turn whirled away. But the microscope teaches us something more about the spleen-pulp and its nature. Borne on the little twigs of the spleen artery we see certain rounded bodies known as "spleen corpuscles." Moreover, imbedded in the pulp we find the corpuscles or globules of the blood in all stages of breakdown and in all stages of construction. So that a second conclusion regarding the organ seems warranted-namely; that it is closely connected with the blood, and with the 
elaboration of the elements which go to make up that all-important fluid.

Let us now appeal to other facts for further details about the spleen. After it has been removed from an animal's body, we note an increase in size of certain other organs; to wit, the lymphatic glands and allied structures. Here we see a balance of power illustrated; and, as these glands certainly deal with the elaboration of the blood, it is a just inference that, as they take on themselves the work of the absent spleen, the latter organ must discharge much the same duties as the glands in question.

Nor is this all. An appeal to the facts observed by physiologists and physicians reveals that more white blood-globules exist in the blood that leaves the spleen than in the blood which enters it. These white globules are most important elements in our bodily welfare. They perform the office of roving detectives, ever on the look-out for intruding germs and other evil-doers, arresting them and destroying them before they can work their effects upon our frames.

Again, the natural quantity of white blood-globules is vastly exceeded when the spleen is irritated by disease; and these facts prove that in some way or other the organ is likely to be a manufactory of white blood-corpuscles. Turning again to the spleen-pulp, why is it that we find in it, as already noted, large numbers of red blood-corpuscles in a stage of dissolution? There is suggested naturally the reply, that the spleen, in addition to its work of making white blood-globules, acts as a place or depôt in which the worn-out and useless elements of the blood are broken up and disposed of.

This, then, is the solution of the mystery of the 
spleen. It is like a ship-breaker's yard, or, rather, more closely resembles a railway depôt. The old and useless rolling-stock of the blood is got rid of within its environs, while new rolling-stock is built and prepared for the varied uses of the system.

After all, the story of the spleen, as told us by modern science, is not a whit less wonderful than were the fancies indulged in regarding its duties by the classic writers. It is surely not less wonderful to think of the mystic work of the spleen in thus assimilating, building, and constructing the new blood-elements, and, in turn, of dissolving and breaking up the old ones, than to think of it, as it was regarded in ancient days, as playing a part in the constitution of the mind and its moods. The old legends have passed away, and have, like the worn-out corpuscles, died a natural death. The spleen is a figure of modern science itself, which reconstructs and remodels that which is old, and presents us with new ideas which are none the less fascinating because they are true. 


\section{XXXVII.}

\section{Tbe Tongue and \$peecb.}

A YEAR ago, when strolling through that most notable of picture galleries at The Hague, I took a welcome siesta in front of that striking picture of Rembrandt's "The Lesson in Anatomy." Doubtless the picture has a gruesome look to the non-scientific mind; but as a representation of a dissertation on the bodily structure, such as was given in the olden days, it has, of course, no rival. Standing out prominently amid the lights and shades of that valuable callvas, one figure arrests the attention of the spectator. It is the professor or demonstrator who is expounding the structure of the dead body to his audience.

For a while, I puzzled myself where I had met with the name of the learned Dr. Nicolas Tulp, of Amsterdam, whom Rembrandt has thus immortalised in his picture. A retrospective mental glance served, however, to fix the source of my impression. I had been diving into the literature of that most curious topic, the tongue in relation to speech, and had met with a reference to a notable work whereof the worthy Tulp was the author. He was born in 1593, and died in 1674, and, by all accounts, was a man learned in medicine and surgery, and esteemed as a good citizen and patriot as well. Four times was he elected Burgomaster of his well- 
beloved Amsterdam ; and we learn, moreover, that when certain weak souls counselled that the city of the dykes should be handed over to Louis XIV., Tulp was one of the foremost in advising a patriotic resistance to the proposal.

For full fifty years, we learn, Tulp practised medicine in his city. As was usual with a man of acute observation, he contrived to place on record not a few of the curious experiences he met with in the course of his practice. For example, in I652, Dr. Tulp published at Amsterdam a work entitled "Observationes Medicæ," and in the course of this treatise we find him relating a case of interest in connection with the tongue in its relation to speech. It had been hotly debated whether or not the "unruly member" was absolutely necessary for speech. Tulp's opportunity of contributing to the elucidation of this question arrived with his observation of a case in which a man's tongue had been removed, and in whom, therefore, the facts of its relation to articulation could be conveniently studied.

The man was called Joannes the Dumb. He lived at Weesp, a town about eight miles from Amsterdam, and now celebrated for its great cocoa works. It seems that in one of his voyages Joannes had fallen into the clutches of pirates, who, imbued with proselytising desires, sought to make him embrace the Mohammedan faith. But the Dutch courage was strong, and the Dutch nature stubborn. Joannes resisted the polite request of his captors, and, as a result, his tongue was duly excised by way of punishing him for his nonappreciation of the piratical offer. He returned to Holland, and was unable to speak. But, some three years after his return, Joannes received another severe mental shock in the shape of a flash of lightning, which 
unexpectedly disturbed and alarmed him. The result of this shock was the literal loosening of his hitherto absent powers of speech.

Naturally the incident was bruited abroad as a wonder, and Dr. Tulp proceeded to Weesp as a student of science, determined to investigate the matter to its end. There was no doubt whatever that Joannes the Dumb had recovered his power of speaking. Dr. Tulp tells us there had been mutilation of half his tongue, and that, notwithstanding this defect, the dumb man spoke, and accurately pronounced "one and all the consonants, the enunciation of which," adds Tulp, "is attributed by the most sagacious investigators of Nature to the tip of the tongue alone." The recovery of the power of speech was, probably, correctly enough interpreted by Tulp. One mental shock may deprive us of speech, just as a second shock may loosen the recalcitrant function and set the mental machinery in operation once more. Apart from this latter point, however, no doubt remains regarding Dr. Tulp's observations, and Joannes the Dumb remains on the page of history as one case notable in the series of allied experiences of science.

Later on, in I7 I8, M. de Jussieu published, in the Transactions of the French Academy of Sciences, the case of a Portuguese girl, who, although born minus a tongue, spoke distinctly and easily, although there were certain consonants, such as $c, f, g, l, n, r$, and others, which were pronounced with some amount of inconvenience. Then comes the case of one Margaret Cutting, of Wickham Market, in Suffolk, who having lost her tongue as a result of some affection or other of the organ, could nevertheless pronounce "letters and syllables very articulately" (sic) - a fact testified 
to by three worthy persons, one Benjamin Boddington, Turkey merchant; William Notcutt, a minister; and William Hammond, an apothecary. The case of Margaret Cutting has the honour to figure twice in the Transactions of the Royal Society of London, the first of these accounts having been read in 1742 . Miss Cutting herself testifies in a letter to her ability and happiness at being able to speak perfectly; and one might have been gallant enough, had the times and days been nearer our own, to have congratulated her on the power of exercising a feminine privilege despite the untoward accident which had deprived her of the organ of speech.

Readers of that most useful little text-book, Huxley's "Physiology," will recollect that the learned author describes in detail certain recent cases in which, in the absence of the tongue, the power of speech has been, on the whole, well exercised. Mr. Nunneley, the famous surgeon of Leeds, gave an account of a case in which his advice was sought in $\mathrm{I} 86 \mathrm{I}$. The subject of this memoir, whose tongue had been removed for disease, was keeping a public-house in Wakefield in the year just named, and Mr. Nunneley remarks of his speech, that " casual observers would only suppose he had some little impediment in his articulation."

Sir Charles Lyell, Mr. Huxley, and others saw the subject of Mr. Nunneley's memoir. All the letters of the alphabet were distinctly repeated to Sir Charles Lyell, although, curiously enough, the word "Leeds" was pronounced with difficulty. Mr. Huxley found that this man could not pronounce "l's" and "d's" initial and final. Thus "tin" he pronounced "fin;" "toll," " pool ;" "dog," "shog;" "dine," "vine." The letters $t$ and $d, \mathrm{Mr}$. Huxley adds, require the tip 
of the tongue to be brought well up to the teeth in front of the palate, and in this case, such an act was; of course, impossible. Again, consonants, such as " $v$ " and " $z$," were given imperfectly because, for their correct pronunciation, the tongue must be in contact with the front part of the palate. It was also curious to observe that all the sounds made when the tongue is brought in contact with the hinder part of the palate were correctly rendered by Mr. Nunneley's patient, with the exception of the final "g." Mr. Huxley explains this on the ground that, "for a good final ' $g$,' the cavity of the back part of the mouth must be completely stopped by the tongue." These curious cases open up for us a new view regarding speech.

They may also serve to remind us explicitly that speech even more truly is in its essence a brain-act; and that even given a perfect tongue, we are unable to exercise it unless the brain's health and vigour are intact. 


\section{XXXVIII.}

\section{Town Iife and its Effects.}

My late friend Dr. Milner Fothergill, among the many trite things to which he gave expression in his writings, laid stress upon the fact that our town life is in itself a cause of the degeneracy of the race. He was followed by Mr. Cantlie (now of Hong Kong), who, if I mistake not, alleged that it was well nigh impossible to trace a pure-bred Londoner and his kith and kin beyond the fourth generation. Other writers have directed attention to the same grave problem of city life and its conditions as affecting the race. They point to the tremendous influx of country life which takes place yearly into London and other great centres of population, and they tell us that the city owes its chief vitality to this infusion of fresh, healthy blood into its masses.

But in time these infusions will be affected by the prevalent causes of town-degeneration; and so the great mill of life continues to grind us down, slowly, it is true, but to grind us out in time (say the physiologists) altogether. Of course, the causes of the degeneracy which city life is said to effect are to be found in the generally unhealthy conditions under which existence is pursued. Pure food, pure air, and pure water form the tripod of life in so far as our 
surroundings are concerned; and it is precisely these conditions which are not typically represented in our great centres.

As to house accommodation, it is only of late years we have been awaking to the ideas that it is nothing short of disgraceful to permit cellar-dwellings and dilapidated tenements to be inhabited at all; and that to screw out of the poor of the slums an extortionate rent for houses compared with which an ordinary pig-stye is cleanly and sanitary, is an extortionate, unjust, and crying evil.

The fact is that, the moment we have to deal with masses of human beings, aggregated together in cities, and living under conditions which violate every rule of health, we come upon causes of physical degeneration which are too evident to admit of theoretical modification, far less denial. An author has taken the trouble to total up for us the number of persons engaged in some half-dozen sedentary occupations in London in I881. We find his figures to give us : indoor domestic servants, 258,709; general labourers, 78, I I 5 ; milliners, \&c., 7 I,837 ; clerks, 60,605 ; tailors, 4I,22I ; and carpenters, 38, I43. Thus, out of some 548,000 persons, about four-fifths lead an indoor life, and, of these, two-fifths (or 173,000) follow purely sedentary trades.

What sedentary life means to the units which follow it closely most of us may know. It implies the want of the first essential for healthy life-pure air-and it includes yet another condition of vitality-free and open-air exercise. Deterioration of frame in the one generation, we have also to note, is transmitted with tenfold force to the next. As health is cumulative in its effects, so also are disease and degeneracy; so that 
the mere pursuit of life and life's avocations in a big city must, in the cases of sedentary workers, be attended not only by an increasing lack of vitality, but by a transmission of the weakness to succeeding units. And there comes a point in this handing on of feeble health, says the sanitarian, when the climax is reached in the shape of the absolute dying out of the enfeebled stock.

The author from whom I have already quoted reminds us that if we treat London as a kind of county or area by itself, we find that out of every 1000 persons in London $37 \mathrm{I}$ are country-born. An immigration of 37 per cent. thus represents what the London population owes to country blood. Again, Mr. Galton is emphatic enough in his calculations as to the percentage of the supply of units (to the next generation) which is represented in rural and city districts respectively. Thus, 1000 families in rural districts will supply about 2334 adults to the next generation, while I000 town families will only supply 1796. The town supply is only 77 per cent. of the country instalment, and to the second generation it is only 59 per cent. of the rural contribution.

Attacked thus from the side of increase and continuance, we see that the failure of vitality in towns makes itself felt on the population question in a very marked fashion; and this accords with what $\mathrm{Mr}$. Cantlie, as we have seen, tells us about the decadence of the pure-bred Londoner. Statistics, proverbially, may be made to prove anything; but in the department of health we tread on relatively sure ground in the matter of figures. Taking London, typically so called, and excluding districts which are more or less suburban in character, we are told that, comparing it with healthy 
districts, the difference of death-rate is at the rate of 9.24 per 1000 per annum. If, now, the population of typical London is set down at $2,767,298$, we discover that 25,559 lives are thus annually lost in consequence of the conditions which prevail in this dense centre of mankind. No less startling is the fact that of every 1000 infants born (I quote from my author once again) I 2 more die under fifteen years of age in urban London than in the healthy districts.

Enough of figures, however; and I know that my readers will remind me that "London is, after all, the healthiest place of any." I reply, on the whole it isfor those who can afford to purchase the best of life's conditions. The healthy London of which my friends speak is a selected London; and their argument is therefore a very one-sided one, after all is said and done. I say to those who argue for healthy London that they represent (the healthy units, I mean) the survivors of a very tremendous general mortality. They are the favoured few who escape, by reason of their affluence, the dangers and degeneration which beset the many. It is the old story over again of the visitor to the slums of a city, who said to his guide that the gutter children looked fairly well and sturdy. "Yes," replied the guide, "but these children play on the graves of their thousand companions who have succumbed;" and what is true of the children of the slums seems to me to hold equally true of the population of every big city we know.

Is there any remedy, then, I may be asked, for this degeneracy which accompanies city life? The reply bears that we may certainly do much to better the existing state of things, and that according to plain health laws. We want the State to take up the 
question of proper dwellings for the masses, if private enterprise fails to accomplish the abolition of slums. We want philanthropists to purchase open spaces for us, and to give to the City lungs for the free respiration of its masses. So, also, we want wider facilities for reasonable recreation, and especially for the workingclasses. More "People's Palaces" will result in fewer gin-shops; and greater facilities for cycling, football, and other games will stave off physical degeneracy as perchance nothing else will or can. Best of all, we must teach the masses the laws of health. We must see to it that in every school physiology and hygiene and domestic economy are duly taught to the boys and girls who are about to leave lessons for the duties of the workaday world.

I have often thought that a hygienic corps, modelled on the plan of the Salvation Army, which could dive into the slums and teach the masses the "A B C" of health laws, would effect a reform for which we must wait as things are. Meanwhile, we are awaking to the knowledge that life may be made better and happier for most of us than it at present is; and in the larger hope of the coming day of health we must learn to labour and-hardest of all-to wait. 


\section{XXXIX.}

\section{A TRainy Day.}

For hours past the rain has been falling, until every leaf and spray has become dripping wet, and the whole atmosphere saturated with vapour. The weather today is a perfect realisation of Longfellow's poem. There has been no stirring outside the domicile. Not even an invitation from a friend (in waterproofs) to fish eels in the brook could tempt me out of my snuggery, where, deep in "Robert Elsmere," I have been passing the hours of the morning. True, eels will and do bite in wet weather more readily than other denizens of the brook, perhaps, and there is good fun (from an angler's point of view) to be got out of a nice two-feet lively member of that serpent-like race of fishes. But the charms of an enthralling book and the genial warmth of the first fire of the season are together sufficient temptations to remain indoors. There is no sign of a clearing yet. Mr. Piscator is yonder in the meadow whipping the stream. The macadamised road in front of the snuggery has been washed almost bare of its dust and débris, and the side-channels overflow with the downpour from the clouds.

Looking at that road, one sees something suggestive of bigger things than raindrops, and mightier currents than the streams of the pathway. Observe how, 
between the imbedded stones of the road, the waterdrops gradually collect to form rills. Note again, how the little rills unite to make streams. See how rill joins rill, until quite a respectable current, as to size, runs into the channel of the overflowing gutter. The gutter itself is made and formed by such rills. The road is, indeed, the "catchment basin" of the rivers, which its gutters represent. If you were to draw a map of that road, its rills, rivulets, and gutters, you would imitate clearly and closely the chart of every big river you know. For, in truth, the biggest river differs only in kind, and not in degree, from the rill on the road. It is fed and nurtured by its streams, exactly as that gutter is fed before your eyes to-day. There is a whole lesson in physical geology spread out before us this rainy day, in the shape of that soaking roadway; and from small things at home to great things abroad, is but a step which the scientific use of the imagination will bridge over easily enough.

Look again at the rills in the road, and note the work they are accomplishing in the small arena they occupy. For see, how the road is washed bare by the rain, its dust-particles having been swept away to the gutters at the sides. This is the first work of the rill and the river alike. Each cuts out a channel for itself - the river through the land, on a big scale; the rill between the stones, on a small one. Again, each is a carrier and transporter of the débris which it detaches from the land. The sodden and dirty water of the gutters is the result of the sweeping away of the things of the earth by the rills. If you take up a tumbler of that gutter-water, and allow its sediment to settle, you will find it is one-half mud. Multiply your one tumbler-full of such débris by the thousands 
that have flowed along the roadways to-day, and you may estimate how great must be the amount of solid matter which a rainy day disposes of, in that it sends all its material first to the rills, then to the gutters, and finally to the brooks and the rivers themselves.

Turn your thoughts next to the rivers of the world. The same action meets your mental gaze that you see in that roadway. The river is an eater-away, an eroder, of the land; and it is likewise a transporter of the materials it steals from the solid earth. Be it slow or be it rapid in its course, its action is essentially the same in character. When you come to multiply the daily wear and tear of the river by its yearly work, the amount of material it is seen to carry down to the sea is found to exceed belief. Think of what the Amazon, and the Mississippi and Missouri, the Danube, Volga, Rhine, Rhone, and even our own Thames must accomplish in this work of earth-wear day by day! Millions of tons of matter are removed from the land, from mountain-peak and valley alike, and carried to lake or sea; just as the rills on the road pour their burden into the gutter beyond. There is no cessation to this action. It is perennial, incessant, everlasting, as a world-phenomenon, and will continue until this orb of ours becomes a waterless, dried-up cinder of a globe like the moon itself.

This action of running water is, in truth, a serious thing, speaking geologically. For the tendency of every rill and river is to wear down the land-surfaces through which it flows to the level of the sea. If you open a geological text-book, you will find the rate at which each river performs this work of earth-sculpture duly chronicled. It is not the least interesting part of the history of running water, 
however, to find that, on a miniature scale, the rain-rills in the road are doing their best to emulate the work of their greater neighbours of the valleys and the plains.

You have seen how the rills of the road cut out their channels through the interstices of the stones, and shape their course according to the obstacles they encounter in their journeys to the gutter. Each rill is like your winding river. With a spice of philosophy, it goes round what it cannot sweep away. This is the case with many a stream you know which meanders through flat-lands, without the flood and force necessary to carve out a straight course and to sweep all before it. The Thames in its flat-lands, or the "sweet winding Devon" of the north, whereof Burns sings, illustrate rivers which flow in a sinuous course because they have not the force necessary to sweep away the obstacles which oppose them. But when you read of the doings of such a river as the $\mathrm{R}$ io Colorado of the West, your respect for the work of running water increases vastly in extent. The Colorado river, in part of its course, runs through rocky defiles, or "cañons," of immense depth. These cañons measure in some parts more than a mile in depth, and extend for many miles as the natural course of the river. Now, it is provable that the river itself has actually made these cañons. It has slowly, but surely, through the long ages, cut and carved its way downwards through the rock, until it has found a channel a mile deep from the surface. Geologists will tell you that this river has been a successful sculptor of the earth, because its waters carry just a sufficiency of sand to eat out, as does a file, the hard substance of the rocks. This is river-action on a 
great and grand scale, it is true; but nevertheless it leads us backwards, by simple enough steps and gradations, to these rills of the roadway and to the gutters by the side of the street.

One word more before you draw the blinds and shut out the dismal prospect and the dripping rain. All is not waste in this action of running water. The material torn from the land is not lost to the world; it is only changed in its form and uses. Deposited in lakes and seas by the rivers, it will form the matter from which new rocks will be constructed. Nay, even to-day, many a river filling up its lake is a land-maker, just as you see that drain yonder has become choked with the débris of the rills. The Mississippi has, for centuries, been making new land at its delta out of the débris of the old. To-morrow, you may see how the water-borne material has been deposited at the drain-mouth in the road, as it is being laid down everywhere in the world's history by the rivers that thieve and steal from the land with one hand, and give back their spoil with the other. Such are the lessons which are taught us by a rainy day. 


\section{XL.}

\section{Tbe $\mathfrak{I} e s s o n s$ of a Quarry.}

Not far distant from my home is a famous quarry, which forms a favourite hunting-ground of geologists. The temptation of a fine spring day has led me in the direction of this big hole in the ground, whence the builders in my locality have obtained the largest share of material for the erection of the city close by. Sitting on the low stone wall which separates the quarry from the road, a sight that is more than suggestive meets your gaze. The rock, which has been quarried to a great depth, is a hard durable sandstone, whereof one could have wished that our Houses of Parliament had been built. That fine edifice, as most of my readers know, is in a state of stone-decay. Attacked by the gases of the London air, the limestone at St. Stephen's is wearing away rapidly enough, and is illustrating to the geological mind aptly, but sadly, that process o1 "weathering," which is responsible for so much cosmical wear and tear.

Below us, however, the quarry sandstone is durable enough. The hand of time, with its (geological) fingers of air, frost, and water, and so forth, makes but little impression on this hard stone dug out from its native rock; and if perchance the sandstone is "hard to work," as the mason has it, you get a fair return for the extra 
cost of labour in the lasting nature of the edifice you have raised. The rock in the quarry, you observe, does not exist in one great mass.

On the contrary, you see therein the same appearance which has often met your eye as you have dashed through many a railway cutting at breakneck speed. It lies in "strata," as the geologist terms them-long and fairly regular bands of rock, varying in thickness or depth. This disposition of the rock of the quarry in layers, or strata, is in itself an important matter in so far as the history of the rocks is concerned. For this layered arrangement indicates first of all that the rocks were formed in water and by the agency of water. Let us see whether we may be able to glance backwards in the past with any hope of arriving at a clear conclusion about the forces and conditions which were responsible for the making of this huge mass of building stone, which man has found so useful for the purposes of his life.

How we gain a knowledge of the past of our globe often forms a matter puzzling enough to the uninitiated mind. Events in the history of our world-such as the making of the coal, the formation of chalk, the growth of the old red sandstone, or the becoming of the Silurian rocks-occurring ages and ages before the advent of man, are described by geologists with an accuracy which almost bespeaks the eye of the observer. We can tell to-day much of the history of the changes which have occurred in land and sea, in Europe and elsewhere, with a near approach to certainty ; and all this "prophesying after the event," as it seems, is wonderful enough to cause us to ask how geology acquires its knowledge about the world-the history of the quarry included. 
The calling into play of two important factors in thought explains the whole mystery. First of all, our geologist reasons inductively, from the present backwards to the past-he argues about things he does not know, from his knowledge of present-day things. "The present is the key to the past;" this is the motto of the geologist of to-day. If I place a poker in the fire for a given time, it becomes red-hot; and from this piece of present-day knowledge, I feel I am competent to argue similarly about the behaviour of all other bits of iron, whether pokers or not, and whether they existed ages ago, or exist now.

It is clear, however, that in my argument, I am tacitly leaning upon a very sound and stable principle, which forms the second factor in geological logic. If the behaviour of pokers in the present is the key to the knowledge of pokers in the past, I must be well assured of one feature about bits of iron, and fire, and, indeed, all other phenomena of Nature-namely, that they are all governed by defined laws, which act uniformly, and which are not subject to erratic change. I am leaning in my argument, in short, upon that principle we call "the uniformity of Nature," and this is, in truth, a very stable support. For, from astronomy to the ways of living things, we do not find the universe to be dominated by erratic behaviour. On the contrary, its affairs are governed by stern immutable laws, the very rigidity and regularity of which form the glory of astronomy, and the great pride of mathematical science.

With the affairs of the world, viewed as a mass of rocks, the case is the same; and the geologist, therefore, is on safe ground when he reads the past in the light of the present. The forces now operating in and 
upon the world - frost, ice, snow, internal heat, animals and plants, water, and atmosphere-he declares, with reason, are exactly those which have always been at work moulding and sculpturing the earth's crust. Rivers and seas and glaciers, volcanoes, and earthquakes, act to-day as they have always worked in the past. The differences in their work have been merely those of degree and not of kind ; and thus postulating the uniform way of the world (in a geological sense) he proceeds to reason about its past from his observation of its present affairs.

Our quarry's history becomes clear enough in the light of this reasoning. Where, to-day, do we find any approach in nature to the making of a quarry? The geologist says, you see such evidence chiefly in the case of lakes, and also, to some extent, it may be, on the shores of shallow seas. Think of your lake for a moment. Into it run rivers, bringing the débris they have worn and stolen from the land. This wear and tear consists of sand, mud, gravel, and like material. It is all deposited in the bed of the lake, and it tends moreover to arrange itself in a given order. The heavier matters sink lowest; the lighter sand and mud lie on the top.

There is thus a tendency to arrangement of material seen from the first in the case of the lake-bed. Now, extend your glance, by a scientific use of the imagination, forwards through a good few centuries. The old lake is being gradually filled up by its river-débris, and its further history is one of choking and extinction in so far as its lake-character is concerned. The lake is now a swamp or morass. Its rivers flow through, over, and above the spot into which they were once accustomed to pour their waters. 
By-and-by there come changes of land-surface. There may be sinking, or there may be upheaval. In any case, the old river-course becomes altered, and the filled-up lake-basin is seen to form part and parcel of the solid land. Its materials have been consolidated and massed together, and for long ages it lies buried and unheeded in the earth's crust. Then man arrives with his prying demand for building stone. He ferrets out the presence of rock below the site of the old lake-bed, and soon the superficial débris is cleared away, and the strata of rock below are laid bare.

For the river-material has become rock, and it has arranged itself in layers or strata, because of the regularity of its deposition in the water. The "wear and tear" of a former state of things have become the rocks of to-day; just as the river-worn substances now being hurried into lake and sea will become the stratified rocks of the future. Our quarry is part and parcel of an old filled-up lake-bed; and we know this, because, in the words of geology, "the present is the key to the past;" and because the history of our world may be read and written on the same lines as those whereon the story of the quarry is made plain. 


\section{XLI. \\ The Ftory of the 3 slantos.}

THE usual definition of an island as a piece of land surrounded by water may do very well for the elementary school and for infantile minds, but I am not sure that it should suffice for any stage of culture beyond the lowest and simplest. For there happen to exist ways of looking at islands which, while accessible to everybody, appear to me to unite in themselves all the merits of a true educational system. Stating my belief in another fashion, I declare that ordinary and common modes of teaching geography are not only dull and uninteresting, but fail to impart any adequate notion of the form, configuration, and, least of all, the history of our earth.

Your ordinary text-book of geography, "as she is written," talks barely and baldly about the size of countries, their boundaries, their rivers and lakes, capes and headlands, their populations, their religions, and their chief products. These are all facts, no doubt; but they are facts which resemble pearls destitute of any string whereby they may be converted into a necklace, and thus made useful and ornamental, both.

My belief, therefore, leads to the assertion that we should become more scientific-but not thereby less popular-in our geographical teaching in schools; and 
this very subject of islands shows the way of reform. Science, in this sense, dives below the bare facts of the text-book, and seeks to give reasons for these facts. It places itself in the position of an expositor and expounder of the manner in which our world and its affairs have come to assume their existing order.

Geographically, all islands are regarded as of much the same constitution. They are detached masses of land, surrounded by sea, and differing, to the mind of the school-boy or school-girl, chiefly in size. Australia is a big island; Madagascar is not so big; and from Ceylon onwards to Mauritius or the Azores there are found all degrees and gradations of magnitude. This, with a few details about the quarters of the world in which islands exist, and with some ideas about products and peoples, complete the geographical knowledge of the average man and woman. Science takes up the matter where commonplace geography ends its story. It asks, first of all, what islands really are, and how one island differs from another.

As the result of its investigations, science soon discovers that islands may be divided by their nature into two distinct sets or classes. Of these two divisions, the first includes islands which can lay claim to that title from the first day of their existence, in that they have never formed part and parcel of any larger mass of land. Thus we first distinguish the so-called "volcanic" islands, which, like the Azores, have been thrust up from the sea-depths by volcanic action, to form detached masses of land existing, it may be, many miles from a continent or mainland.

Then comes a second class of islands which are called "continental," because, whatever their size, form, or situation, we can prove them to be, geologi- 
cally, part and parcel of a bigger tract of land. They are the separated and disjointed fragments, so to speak; of a larger land-mass. Under this head are to be included many islands we know. The British Islands are simply detached parts of the European Continent; just as Trinidad is a fragment of South America; or as the Malay Archipelago represents the broken-up land which, once upon a time in its hale and solid state, connected Asia and Australia. Even New Zealand and Madagascar are continental islands in their way, although the exact dates of their separation may be very hard to trace in the mists of geological time.

Having thus succeeded in distinguishing between islands which, like St. Helena, the Azores, the Galapagos, and so forth, represent the eruptions into the earth's outside mass of volcanic matter, and those which, like Britain, Trinidad, and the West Indies, are really the detached pieces of large land-tracts, it behoves us to inquire further into the history of each group. We find the sea around our volcanic islands of great depth. They are separated from their mainlands, it may be, by abysses of ocean. On the other hand, the continental islands have, relatively, shallow seas separating them from their nearest continents.

Witness, in proof of this statement, the German Ocean, the English Channel, the sea between Trinidad and America, or the general depth of the seas around the Malayan Islands. We find a test, not only of the nature of an island in the depth of the seas around it -apart from its rock-structure-but, in the case of the continental islands, we can assure ourselves of the length of time they have been separated from their mainlands, by having regard to the same matter of ocean-deepness. The Azores, as volcanic islands, are 
thus separated from Portugal by sea varying from 2000 to 2500 fathoms. Within a short distance from the islands themselves, the sea is about 1000 fathoms deep; within 300 miles it is 1800 fathoms, and soon deepens to 2500. With the Bermudas the case is similar: some 450 miles off, we reach the sea-bottom at 3825 and 3875 fathoms. St. Helena has sea of 2860 fathoms deep between it and Africa, some I 100 miles off. Contrariwise, the sea around our own shores is comparatively shallow; but, as I have remarked, whenever a continental island shows, like Madagascar, a deep channel between it and its mainland, the story such depth tells us is one of long detachment from the mother-country.

So far, islands have shown us that, geologically, their history is interesting in respect of the marked variation between the two classes. Not less interesting is the additional evidence about islands which their animals and plants have to tell. Whence, let us ask, have detached islands, like the Azores, obtained their animals and plants? Upraised from the sea-bed, as were these islands, their living population must have been derived from other and previously peopled lands. This supposition is confirmed by our finding that on the Azores we discover no animals or plants -excluding those of man's introduction-which are not found on the Portuguese coast.

The rabbits, weascls, mice, and a single kind of lizard, found in the Azores, are importations. The birds which, of course, can fly over the intervening sea, are those of Europe; such also are the insects; and such, again, are the plants. In a word, there is nothing about the animals and plants of the Azores which we cannot explain by a reference to their 
European origin. Then also, on such detached islands, we cannot expect to find native quadrupeds or frogs; for these animals will not face and brave a long swim in the sea. In a word, it is precisely those animals and plants which have ways and means of conveyance over tracts of sea which people these distant islands, and come to live and flourish thereon.

Very different is the case with our continental islands. Here, the animals and plants are those of the adjacent mainland, altered and modified only in so far as the length of the separation of the islands indicates and allows. Our British animals and plants are those of the Continent, and the life of Trinidad is that of South America, because there has been no time, practically, for change. But in Madagascar, Australia, and New Zealand, as islands long separated, each from its mainland, we find living things utterly unlike the greater land-mass from which each island was derived. Thus it is that together geology and biology teach us much about islands of which geography takes no heed. 


\section{XLII.}

\section{Tbe Tife of Fslanos.}

IN dealing with the history of islands in our last paper, I referred to the manner in which animals and plants were enabled to pass from one region to another, and thus to people islands which had been raised from the depths of the sea as independent masses of land. So important however, is the consideration of the ways and means in which this dispersal of life is carried on, that the topic is interesting enough to merit the distinction of our further attention.

In the case of plants, it is obvious that the vegetable world possesses powers of dispersion which are unknown in the animal realm. Many seeds are furnished with means for conveyance by the wind, and such as are provided with hard shells may be protected for long periods from the action of water. Volcanic islands owe their plant-life to the chance sowing of seeds, borne by the winds or waves to their shores; and birds also act as important colonisers of such islands through their conveyance of seeds adhering to their plumage, or contained in clods of earth which become attached to their feet.

In the case of the animal life of islands, we note that certain animals are unfitted by their nature and habits to traverse great distances by sea. Such are quadrupeds, and such are the frogs and their neigh- 
bours. On islands like the Azores, far removed from a mainland, and having had no original connection with any continental region, there are, accordingly, no native quadrupeds and no native frogs, toads, or newts to be found.

It is different with reptiles. Many of these animals are good swimmers, and we must also take into account the fact that their eggs may be conveyed on driftwood, and may be thus transported to far distant lands. There exists an interesting problem of this latter kind in connection with the Galapagos Islands. These form a group of volcanic islands, erupted into the Pacific Ocean, and lying about 600 miles off the South American coast. Around them the sea is about 1000 fathoms deep, and between the islands and the American coast the depth may reach 2000 or 3000 fathoms. This is a clear proof-even if we had not their rock structure to confirm the opinion-that the Galapagos Islands are the products of volcanic action, and are original lone masses of land, showing no relation whatever to the nearest continent.

Now, on the Galapagos there are no native quadrupeds (mammalia) and no native frogs; this fact is justified by our scientific expectations, as we have seen. There does exist on these islands a kind of mouse, the true history of which is undoubtedly that of conveyance by man to the Galapagos. But as regards the reptiles, the case is very different: there are land-tortoises, lizards, and snakes. The lizards number five distinct species; but all are of American origin, and find their nearest relatives on the adjacent continent. One of the Galapagos lizards is decidedly aquatic in its habits, and is found swimming freely in the sea, feeding on the seaweed of the island-coasts. 
The lizards give us no trouble in accounting for their presence on these islands. Their American connections point to an origin from that continent; and that they are importations-originally conveyed, themselves or their eggs, on driftwood or even by swimming -to the Galapagos, is a theory of very feasible nature. The snakes are more unusual tenants of oceanic islands. Two species occur on the Galapagos; but both are near relations of South American serpents, and one, it is added, is scarcely to be distinguished from a Chilian species. Serpents are animals which are very tenacious of life, and their powers of swimming are also, on the whole, of a very well-developed kind.

"On one occasion," Dr. Wallace relates, "a boaconstrictor swam from South America to the island of St. Vincent, which is distant 200 miles, at the very least, from the continent." So that, as regards the snakes of the Galapagos, there is even less difficulty than is met with in the case of the lizards. Carried on floating trees, or even swimming across the intervening ocean, into which a river-flood may have swept them, snakes may readily reach lands far distant from their native habitats.

But that which is most interesting in connection with the Galapagos reptiles is the presence on their islands of huge tortoises. These huge reptiles must be familiar to visitors to the London Zoological Gardens. They represent enormously enlarged editions, as it were, of the familiar tortoises of every-day life; so large, indeed, that a man might easily sit on the back of one and be conveyed by the animal without the latter being aware of the burden it was carrying.

Big tortoises are not common animals. We find them also in the Mascarene Islands, which are associated 
with Madagascar itself. But the Mascarene tortoises have been shown to differ from the Galapagos ones, and there are thus practically no traces of these huge reptiles to be found near to the last-named islands themselves. Accordingly, taking his stand upon the general theory which accounts for the immigrantpopulation of volcanic islands, Dr. Günther tells us that the Galapagos tortoises are probably of American origin. They came from the continent, in short, which has given to the Galapagos Islands their other forms of life.

There is, besides, no difficulty in accounting for the passage by sea of these animals. They are very tenacious of life, and many tortoises emulate their turtle-neighbours in the fact of their taking freely to water. Doubtless the original parents or ancestors of the big reptiles of the Galapagos Islands were drifted out to sea by some flood which swept them from their land-haunts. A mass of driftwood may have formed a raft on which they would easily exist for days and weeks without food. Once stranded on the Galapagos shores, these reptiles would find themselves very much at home; and would settle down as colonists in these lonely isles of the sea.

It must be noted, however, that animals thus transported to foreign shores show that tendency to variation in form and habits which is so widely represented in all the children of life. We know, for instance, that as regards many islands of the Mediterranean Sea the lizards found thereon, which are identical as species with those of the mainland, nevertheless develop different colours in their island habitations. They usually become blue or black in tint. As regards the lizards of the Seychelles Archipelago, naturalists can 
tell, by the colour, "from which particular island a specimen had been brought." We learn from such facts the power which local conditions of life possess over living beings in the direction of inducing variation in form, colour, and other particulars. Now, as regards our big Galapagos tortoises, the same rule holds good.

Once introduce an animal or plant to new surroundings, in the shape of food, climate, and so forth, and you may assuredly bargain for alteration of its form and colour. The Galapagos tortoises differ from other big reptiles of that kind; but that the differences are due to this universal tendency to variation is, at the very least, a reasonable explanation, in face of the facts with which we are acquainted. We therefore see in the case of the Galapagos reptiles merely another proof of the wondrous fashion in which living beings suit themselves to new environments: a power of adaptation this, which really prevents the extinction and annihilation of life when placed in strange lands and under untoward conditions. 


\section{XLIII. \\ $\mathfrak{Z}$ Corner of Tkent.}

Strolling from Herne Bay towards Reculvers the other day, I found myself on a coast which is geologically classic as regards the action of the sea on the land. There are few coasts which can tell a more typical story of sea-invasion than this east-coast nook of Kent. Doubtless the sea which encompasses us acts perpetually on all our coasts, but Peterhead granite will withstand the buffeting of the waves for ages, while chalk and marls will go the way of their kind, when attacked by the sea, with amazing rapidity. I often think that a holiday, either by the sea or inland, might be made, for the vast majority of us, infinitely interesting, were the local history of the places we visit made an object of even superficial study.

How many of the hundreds of persons, for example, who visit Reculvers each summer know aught of its history, or realise how, as the old church stands, ruined and desolate, it testifies to the power of the sea on our coasts, and to the great geological lesson of waste of the land?-a lesson as old as Job, who speaks of the waters wearing the stones. The reason why we yawn and grow wearied over holidays is, that we have not learned to invest our leisure time with any meed of interest at all. But with a little geology in one's head, 
and with a mere soupçon of zoology or botany, aided, say, by a microscope, you may spend hours of keenest delight during your holiday-time, and rescue other souls dying of ennui from the horrors of having " nothing to do," which, I take it, are much worse than those attaching to the condition of having " nothing to wear."

This Kentish coast well illustrates the interest which may be made to attach to a simple study in sea-action. The Isle of Sheppey, to begin with, measures about six miles in length by four miles in breadth. Its substance consists of London clay, which is practically about the most feeble of materials, in so far as resistance to the sea is concerned. Now, Sir Charles Lyell records that, between 1810 and 1830 , no fewer than fifty acres of the Isle of Sheppey were swallowed up by the sea. The cliffs on the north, he tells us, which are from 100 to 200 feet high, decay rapidly under the influence of "the weather," under which term, of course, we must include the sea itself.

In 1780 the church of Minster was said to have been situated in the middle of Sheppey: it is now near the coast, so that, as far as the whole isle is concerned, it would not be a difficult matter, as Lyell says, to calculate the period when its annihilation would be accomplished. It is true, man intervenes in such cases with his breakwaters and sea-walls, and thus arrests the otherwise triumphant assault of the sea on the land; but the record of the ocean's victories and spoils is nevertheless a huge one, and the geological thought that all the matter stolen from the land will simply form the rocks of the future, possesses, I am afraid, but a poor meed of consolation for landowners to-day. East of Sheppey we come, of course, to 
Herne Bay itself. Here, sea-action has evidently been long and successfully at work; for of bay there is little or none, and the former contour of the coast has thus been materially altered by the attack of the waves.

Walk across to Reculvers-a pleasant stroll of five miles or so-and you come upon historic evidence of this theft of land by the sea. A hamlet nestles around the old dismantled church, which, with its twin towers, "the Sisters," forms a familiar landmark of the coast. A bungalow establishment lies to the west; below, and in the valley, as it were, are a house or two and the inn; while above, and nearly on a level with the church, is the coastguard station-as neat and trim a collection of dwelling-places as the eye can light upon anywhere, even among these proverbially ship-shape sailors' quarters.

The towers face you as you climb the ascent from the inn, and each is surmounted by a wind-gauge, which the Trinity House has erected, and which you can see distinctly from the windows of the train after you pass Herne Bay, on your way to Margate. The keeper of the towers unlocks the gate of the churchyard, and a conversation with him (he is Reculversbred) reveals the fact that, even in the short space of a human lifetime, the sea has played havoc with the cliff.

This man tells you that he remembers a time when the outlines of the cliffs and bays were very different from their present aspect. The tablet in front of the church tells you that the Trinity Brethren acquired the building in 1810 , and under their care it has remained. Looking down some twenty-five feet or so to the beach, you note the sea-wall, which has saved 
the church from sharing the fate of the cliffs aroundSir Charles Lyell aptly calls it a "causeway of stones." When he visited the church, in June $185 \mathrm{I}$, he beheld human bones and part of a wooden coffin "projecting from the cliff near the top;" and the keeper of the church, referring probably to that epoch, reminded me that visitors were fond of carrying off gruesome relics of the spot in the shape of the remnants of mortality which the sea had exposed on the cliff burial-ground.

We can go back, in the history of Reculvers, to the time of the Romans. Then, it was named Regulvium. It was a military station of importance in those days, and that it was an inland place cannot be doubted. For, in the time of Henry VIII., it was a mile or so distant from the sea. From that epoch onwards there has been a chronicle of sure and swift wear and tear by the ocean waves. The cliff is sand, with clay sandstone in slabs, interspersed among the softer material. This material presents no obstacle to the attack of the sea: so that we are not surprised to discover that when I78I dawned, and a drawing of Reculvers appeared in the Gentleman's Magazine, the mile of intervening ground seen in Henry the Eighth's time had dwindled away to a mere fraction of its former size.

The view of $178 \mathrm{I}$ is instructive. Taken from behind the towers, the church is represented still in its entirety. Looking towards Herne Bay we see an outjutting tongue of land on which stand several houses. Among them is an ancient chapel, now destroyed, while a cottage which stood between the chapel and the cliff was swept away in 1782 .

Before 1780 the ancient Roman camp had come to grief, under the resistless march of the waves, and for a time, we are told, the walls of the camp held firmly 
together (they built stoutly in those days), and overhung the waves, which had undermined their foundations. These walls were nearer the sea by eighty yards than the church, and in 1780 they were recorded as having recently fallen into the sea.

Then comes 1804, when part of the churchyard, with several houses, went by the board. The church itself then entered on its final stage of ruin. It was dismantled and abandoned, and its sister spires were left to form the familiar landmarks of the coast. A drawing taken in 1834 shows us the church very much in its present state. It overhangs the cliff, and to-day "its artificial causeway of stones" alone preserves it from sharing the fate of its once extensive surroundings.

You leave Reculvers impressed anew and forcibly with the power of the ocean on the land, and you learn a lesson of geological value, in that you can realise what science means, when it affirms that, among the agencies which are ever sculpturing and carving the earth, few or none excel in power the waves of the sea. 


\section{XLIV.}

\section{Tbe ¥nroads of the \$ea.}

THE history of Reculvers Church, just detailed, suggests that it may be instructive if we attempt to dive into the story of sea-action on our coasts at large, by way, perchance, of presenting holiday-seekers with niaterial for study when they visit our coasts, and, at least, of affording food for geological thought at large. Britain, as a "sea-girt isle," presents to us notable illustrations of sea-action, and the more so because the rocks of which our various coasts are composed exhibit such an infinite variety of texture, composition, and hardness.

Naturally, certain localities, whereof the rocks are soft and easily worn away, present us with more typical illustrations of the ocean wear-and-tear than those places in which rocks of dense hardness form the bulwarks of the island. But if we inquire into the fate of the coasts in the far north, and pursue our investigations, say, in the Shetland Islands, we may discover that, even on the hardest rocks, the ceaseless beat of the waves in due time makes a very marked impression.

Let us think for a moment what the power of the sea in a storm means. In Shetland, for example, it is calculated, on very exact evidence, that great masses 
of rock, weighing thirteen tons, have been excavated from the cliffs by the force of the waves acting at a height of 70 feet above the level of the sea. When a large wave strikes upon a rock, the pressure of the blow may equal three tons to each square foot. Thuswise, the air which all rocks contain is forcibly compressed, but as quickly, of course, expands when the wave has retreated.

It is chiefly this compression and expansion of the air in rocks which aids and effects their breaking-up by the waves; but the sea has other methods of procedure in its attack on the land. The boulders and blocks which have become detached from the rocks accumulate at the foot of the cliffs. The waves seize these blocks in their grasp, and dash them with fury against the cliffs; using thus the material it has stolen from the rocks as a kind of natural artillery wherewith fresh assault and battery are made upon the land. There is often a definite plan of sea-action to be noted in the case of many coasts. An outjutting portion of a cliff is first of all tunnelled by the waves, so that a natural archway is formed. Then the tunnel collapses, and its outermost part is left standing as a sea-stack or "needle." This stack, bit by bit, is worn down to the sea-level. It grows small by degrees, until it becomes a mere tangle-covered rock, which will be further planed down and worn to nothingness by the irresistible action of the waves.

The Yorkshire coast, as well as the east coasts farther south, present us with many characteristic historical examples of the action of the sea in robbing us of the land. There is one section of the Yorkshire coast, from the mouth of the Tees to the Humber estuary, which has suffered severely through sea- 
action. Old maps of this region do not represent its outlines as they exist to-day, and a comparison of these ancient charts with modern ones teaches us an eloquent lesson of the ocean's power. The rocks in the locality I have just named are, on the whole, of soft character, and present no adequate resistance to the waves. They are composed of chalk, lias, and oolite strata. At Flamborough we see the chalk worn into caves and into needles as characteristic as are those of the Isle of Wight-which, themselves, alter their form and dwindle away year by year. Between Flamborough Head and Spurn Point we meet with beds of boulderclay, which rise to a height of a hundred feet or so. This material offers no resistance to the waves. The tide scours and moves away the gravels which might otherwise protect the bases of the cliffs, and the wearand-tear in this region has therefore been typical in its amount and rapidity.

Whole tracts of land on this Holderness coast have thus bodily disappeared: villages, both seaport and inland, have been swept away. Since the time of the Romans a belt of land nearly three miles broad, has been regarded as representing the loss of territory on this coast. The late Professor Philips calculated that the cliffs from Bridlington to Spurn recede at a rate of two yards and a quarter per year, this action taking place over an extent of coast-line measuring thirty-six miles. Calculated as to the actual amount of land which the sea swallows up, we may safely set the loss down on this part of the coast at thirty acres annually.

The old maps of the coast to which I have alluded present a melancholy list of details in respect of their failure to identify the existing outline of the land. Thus, what were once towns and villages known as 
Auburn, Hartburn, and Hyde, in Yorkshire, are now sandbanks in the sea. Owthorne and Kilnsea, ravaged by the waves, have been rebuilt inland. But Norfolk and Suffolk suffer in equal extent with Yorkshire itself.

Speaking of Sherringham, Sir Charles Lyell tells us that in 1829 , when he investigated the rate of seawaste there represented, some seventeen yards had been swept away in five years. The inn, built in I805, had fifty yards between it and the sea; but in 1829 only a small garden was left; the builders of the house having vainly supposed that the sea would take at least seventy years to reach the inn. In I829, we are further informed, there was a depth of water sufficient to float a frigate -20 feet at least-in the harbour, where, only forty-eight years previously, a cliff 50 feet high, with houses upon it, had stood.

Ancient Cromer, it may be related, is now swallowed up in the German Ocean, and the Cromer cliffs are still being worn away. But the history of the parish and village of Eccles, and the villages of Shipden and Wimpwell, is as instructive as any that may be related of this ceaseless attack upon our coasts. The three villages have themselves disappeared, and the whole coast-line of Norfolk for a length of twenty miles in this locality has presented from time immemorial illustrations of rapid sea-wear.

Of Eccles we read that in 1605 , when pedantic James had come to the English throne, the good folk of Eccles petitioned the King for a reduction of taxes. Their ground of claim was very just and reasonable. No fewer than 300 acres of their land had been swept away by the sea, and all their houses, save fourteen, had disappeared. Lyell tells us that not I 50 acres 
remain in the parish, and hills of blown sand-dunes occupy the site of the houses wherein King James's petitioners resided. In 1839 the tower of Eccles Church could be seen rising from amid hills of blown sand. In 1862, after a celebrated November storm, the sand-dunes were seen to have been blown inland; the tower was bared, and the waves "washed the foundations of the edifice."

From John o' Groat's to Land's End, there is scarcely a coast-line which will not yield ample details of seaaction to the inquiring mind. Landslips may and do occur occasionally, and may hurl cliffs bodily seawards ; the land itself may sink and give up so much of the coast to the waves. But beyond these actions in constancy and power is the work of the sea itself. Indeed, whether grinding the pebbles and particles into the long ribbed lines of sand and kissing the coast with the gentle salutation of the summer wavelets, or grinding the boulders and tearing the cliffs in its winter fury, the sea is ever taking from us the land on which we dwell, and threatening our shores with a fate all the more terrible, because, relatively, we are so powerless to avert it. 


\section{XLV.}

\section{Tbe Grottoes of Than.}

ONE summer part of my holiday wanderings found me in the district of the Ardennes. Whether the Belgian quarter was that of Shaksperean fame, or whether the scene of Arden Forest is to be laid in Yorkshire, is a matter with which, happily (not being an archæologist), I have nothing whatever to do. Suffice it to say that, after a week spent in roaming about Dinant all-picturesque on the Meuse, and in making journeys to the ruins of Montaigle and to Maredsous and elsewhere, I set off for the Ardennes proper, and drove away one fine August morning en route, first of all, for Rochefort and the famous grottoes of Han.

In passing, let me recommend the Great Eastern Railway's tour to Dinant (via Harwich) and the Ardennes as a pathway to holiday-making of pleasantness combined with speed, and with what the paterfamilias will regard more favourably still-namely, high economy. Arrived at Rochefort, then, some four hours' drive or so from Dinant, you find yourself in a tolerably primitive Belgian district. The railway has not succeeded in spoiling it, although crowds flock daily in summer to see the grottoes of Han, which, by the way, you may notice advertised on the hoardings in the Belgian capital itself. 
There is a grotto at Dinant which is, in its way, well worth seeing. You enter it from the main street of the village, and it leads you right up through the limestone cliffs to the top thereof, and you can come down through the gardens of the Hotel de la Tête d'Or if so happen you are resting at that familiar caravanserai. But the Dinant grotto "pales its ineffectual fires" before its neighbours of Han, which, being tolerably near us, should certainly be visited by all geologically minded Britons at least once in their lives.

You drive from Rochefort to $\mathrm{Han}$ on the usual lumbering diligence or char-à-banc, and the drive is pleasant enough in its way. It occupies the best part of an hour, and there is the usual needless foreign delay about starting for the grottoes when you do get to Han village itself. In the lobby of the hotel at Han hangs a whole set of smock-frocks or overalls, and visitors may don these if they please. But I found no need for these protective garments (as an old geologist I scorned them, in fact), and those ladies who donned waterproofs (and who wore thick boots, by the way) came off in their turn exceedingly well.

Cave-hunting is apt to be wet work now and then, and below foot it is often muddy here and there; but, as far as the Han grottoes are concerned, there need be no great fear at any time on account of one's garments. There was quite a procession of visitors on the occasion of my visit to Han. Over eighty persons wended their way through the caves. We were a motley crew-English, Irish, Scotch, French, Belgians, Germans, Spaniards, one Russian, and the usual contingent of our American cousins. The ladies were present in fair proportion, young and old alike; but 
the prettiest and most winsome of them all hailed from the county of Cornwall, and from that fact made, I suppose, an excellent underground explorer.

When we did make a start, we were led a mile through the fields and copses by a female guide, who conducts visitors to see a rather interesting piece of behaviour on the part of the river Lesse. Into a big swallow-hole the river is seen to tumble, and is lost

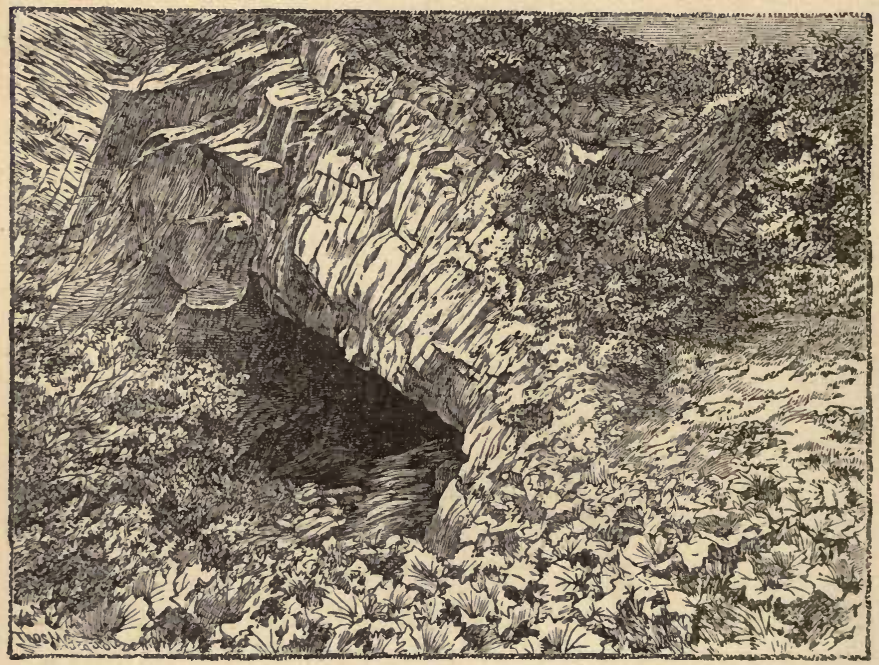

Fig. 35.-Cave into which the Lesse disappears.

to view. Not for a mile or so does it appear again, calm and peaceful, as if nothing the worse for its subterranean passage. Then back again you trudge to the mouth of the grotto itself, where you hear an official recitation by the master-guide to the effect that you are to pay five francs per head, with an extra half-franc if you desire a cannon-shot fired in the exit cavern. Wise persons will not desire any such 
thing. It is only a great deafening roar-which, by the way, you hear just as well outside, as if you had paid your half-franc extra "for a fine headache," as a sober English vicar put it last summer.

Armed with two paraffin lamps, one at each end of a crossbar, are the lads and lasses who walk one between every two or three visitors to show the way through the Stygian darkness of the caves. We fall into line and start off down stone steps into the gloom of the grotto. At first we follow apparently the windings of the river channels, and in succession pass through a series of caves, or salles, representing the slower work of water as regards their excavation.

The Salles Marée and Nouvelle are thus passed through, and then comes the Salle des Scarabées, deriving its name from the beetles which fed on the remains of the prey devoured therein by the foxes, which have given their name to the adjoining Salle des Renards. Now and then the guide, whose conversation is of a highly voluble kind, stops to direct attention to the wondrous limestone formations that mark the interior of the various caves. There are stalactites and stalagmites by the hundred, large and small.

Occasionally you may fancy you are standing in the nave of some cathedral, while at the next step you come face to face with a mass of limestone which has dripped and dripped through the long ages and in the silence and darkness until it has come to assume the form of a veritable solidified sheet of water. Hence the name of "cascade" it has received. The glare of the lamps causes this mass of limestone to glisten as if it were frozen water. Then we ascend higher, until we come to the Salle Vigneron and its curious 
stalagmites, which bear a close likeness to the pipes of an organ. Through grotto after grotto we passnow seeing the limestone wrought into the semblance of flags, in the Salle du Trophée, which has an arch over a hundred feet high, and now beholding the magnesium light of the guide reflected in a thousand sparkling coruscations of light and colour from the sides of the caves.

Later on, winding steps lead us to the Salle du Dôme, and we find ourselves in a vault 200 feet or more in height. Below the ledge on which we stand, rolls in darkness the river. Away up and beyond us is a mystic arch, as distant from us as the topmost seat in the gallery of a large theatre is from the stage; and at the top of the arch is a mass of stalagmitic rock, called Pluto's Throne. Now, the guide, torch in hand, mounts away upwards to the throne. Your eye follows him as he leaps from peak to peak like some weird spirit, and finally, as he rests on the throne torch in hand, he has lost everything that is human in aspect, and appears from afar as the sombre guardian and king of the nether world.

Below us, another guide dives down into the depths, and by the light of his torch shows us the black river flowing silently on. On this veritable Styx we all embark in two huge boats, and the plash of the oars sounds weird and strange in the caves. Ahead of us, at last, we perceive a curious pale-green light, resembling moonlight, but with a colour such as Luna's rays never possess ; and a few strokes of the oars bring us out into the light of a glorious summer's afternoon, after our two hours' travel through the earth. There is a walk of half a mile or so back to the hotel, and finally we board the diligence and trundle back to 
Rochefort, in time for the inevitable poulet and veal of the Belgian rural table-d'hôte.

This is a brief account, and a very imperfect one to boot, of a very notable excursion. To those of my readers who are in want of a new sensation for Easter or summer holidays, I say, "Go to Han and see the grottoes." There you will be taught, as nothing else can teach you, what underground water, aided by the dissolving action of carbonic acid gas, effects in the way of eating out huge caverns in the limestone rocks. Truly, it is the only fashion in which you may study geology this - by interrogating Dame Nature personally, and seeing the changes she is able to induce when, through the operation of the element of time, the waters are made to wear the stones, and the huge cliffs are tunnelled into the grottoes and the caves of to-day. 


\section{XLVI.}

\section{Coal at Dover.}

Although ordinary folks may not be very well versed in the facts of geological science, the announcement that coal had been found at Dover must have created some considerable amount of surprise. There is no district which less resembles the Black Country than the coast of the Channel, and it may be said that the unexpected, which always happens according to popular tradition, caused as much sensation in the ranks of science as it did beyond the confines of the learned circles. Yet the fact remains that below the chalk cliffs which form the characteristic mark of Albion the Perfidious, the black diamonds have been discovered, and a new source of industry - such as will not please Mr. Ruskin at all-is likely to be opened up close by the historic Cinque Port itself.

The men of Kent, instead of importing their coals from afar, may, in their turn, take to selling their carboniferous products to their less fortunate neighbours, and a geological discovery may, in truth, thus revolutionise a whole county. It seems that the suspicion that coal was to be found beneath the chalk, and within accessible distance of the earth's surface, is no recent speculation in geology. Some thirty-five years ago Mr. Godwin Austen laid before the Geological 
Society of London his views on this subject, and declared his belief in the existence of the valued mineral below rocks from which the coal was ordinarily presumed to be separated by many thousands of feet of different rocks. To enable us to understand the bold nature of this speculation of Mr. Austen's, we require to bear in mind the teachings of geology concerning the succession of the rocks which compose the crust of our earth.

First of all, let us note that the various ages or periods into which time past has been mapped out by geologists, correspond to or with as many groups of rocks, each marked by its own special structure, fossils, and other characteristics. Then, in the second place, we have to bear in mind that the order in which one rock-formation succeeds another never alters. Take as an example of this stable order of the rocks the following: the Coal rocks, in their natural order, lie above the Devonian or Old Red Sandstone, while, in turn, they are overlaid by the Permian rocks.

Thus, if we could see in any district a section showing the complete thicknesses of these three rockformations as they were deposited, we should find the oldest or Devonian strata lying lowest, the Coal in the middle, and the Permian above the Coal, this last formation being the youngest or most recently formed of the three. Suppose, further, that a person on whose estate the Devonian rocks came to the surface consulted a mining engineer as to the probability of coal being found beneath the soil of his possessions, it is very clear what the reply of the scientist would be. He would say that as the Coal is a younger rock than the Devonian, and was therefore formed after the latter, and as it lies in its natural order above the 
Devonian series, to spend money in boring for Coal through the Devonian would be as futile a proceeding as that of trying to lift water with a sieve.

Suppose, however, that the surface rocks of the estate were of Permian age, and that these latter rocks were not inconveniently thick, then the prospect of finding coal measures would amount well-nigh to a certainty. It is this succession of the rocks which forms the basis of all geological calculations about the finding of minerals and concerning the nature of the rocks which occur in any locality. It is this very thought which has to be taken into account in discussing the occurrence of coal at Dover.

If we inquire into the order of the rocks which crop up to the surface at the coast, we find them, of course, to belong to the Chalk series. Now, the Chalk is a long way younger than the Coal. It belongs to quite a distinct period of the earth's history from that which witnessed the growth and luxuriance of the Coal vegetation. Tracing the succession of the rocks from the Coal to the Chalk, we find the Permian lying, as we have seen, above the Coal. Then we pass upwards in point of position, and onwards in point of time, to the Trias formations.

After and above the Trias come the Oolite rocks, and, finally, above the Oolite lie the Chalk rocks themselves. These formations are divided each into a whole series of subordinate strata marked by local and other peculiarities; but the main point for us to keep in view is the plain fact that if the Coal rocks are separated from the Chalk by the Permian, Trias, and Oolite formations, which attain many thousands of feet in thickness, it would seem a practically hopeless idea to expect to be able to reach the Coal by any amount 
of boring capable of being carried out by human appliances.

Yet there is one consideration which comes to the aid of the geologist, who has to face many problems of very perplexing kind. What should we say, let us ask, if certain of the rocks lying in the natural order of things, between the Coal and the Chalk, happened to be absent? What if the Trias and Oolite, together with the older and scarcer Permian, had somehow or other slipped out of the series altogether? What if some geological cataclysm had swept them away, so that at Dover and elsewhere the earth should see the faces of these rocks no more for ever? Clearly, if these suppositions possess any grains of reality at all, the effect of the thinning away of the rocks between the Coal and the Chalk would practically be to bring these two formations into relatively close proximity.

Now, this is precisely what we know has occurred elsewhere. Mr. Godwin Austen long ago, told geologists that, from his study of the coalfields of Somerset and South Wales, and of Belgium and Northern France as well, he was certain coal also lay buried under the rocks of the intervening regions. If this idea were to be entertained, then it followed that underneath the white cliffs of Dover there was a possibility of coal being found. The only question remaining then came to be, Could it be reached from the surface so as to make it available for the use of man? Again there was support for this idea in the fact that coal is being worked in both France and Belgium, beneath the same chalk rocks which environ our shores.

There had been borings carried on in Sussex in the Wealden formations, which, as the lowest of the Chalk, 
were supposed to afford the best chance of getting at the strata below ; but this work had to be abandoned on account of an accident to the boring tubes, after some 1900 feet of strata had been passed through. In the London district a noteworthy observation showed that Devonian rocks older than the Coal had been met with at about 1000 feet from the surface. Clearly, then, it was a hopeful enough prospect to expect that the Coal itself might be met with under similar and favourable auspices.

The boring operations, as all the world knows, were duly resumed at Dover, and the section made-at Shakspeare's Cliff began with the Lower Grey Chalk, and, after 500 feet, passed to the end of that formation. Then succeeded 660 feet of thickness of strata, belonging to the Oolite rocks, which, as we saw, lie below the Chalk. The crucial point came next in order. What lay below the Oolite formation and beneath the Bathonian measures which formed the lowest set of Oolitic age? The reply of the boring came clear and distinct - in a single word, Coal.

Professor Boyd Dawkins, who has all along taken a deep interest in the solution of this interesting problem of geology, tells us that the coal measures at Dover were struck at a distance of I 80 feet from the top of the bore-hole. This is 68 feet below the point at which the coal was met with in the Calais borings. The Wealden strata, he further tells us, are thinned off in a remarkable manner, inasmuch as they are seen at Hythe and Folkestone, but at Dover are wanting, and this absence of the Weald rendered the work of getting at the coal all the more favourable.

The Dover coal is said to be of good blazing variety, and one may, therefore, anticipate the time when Kent 
coal will be quoted in the lists of the London dealers in the black diamonds. This is the economic side of things; but doubtless our coal-dealing friends will take good care that the price of coals is not at all reduced by the fruits of geological discovery. The scientific side is more to the point at present, and we may learn how exactly scientific prophecies come true in the case of the Dover coal. Scientific prophecies, however, have this great characteristic, that they are founded on certain pieces of evidence rather than upon the misty convictions and beliefs of dreamers who are always prophesying about events that are never likely to occur -in our time, at least-and among them the end of the world, which I understand a hopeful and sanguine professional prophet has decided will happen in the year 1893 .

Science reasons, in other words, about what is still in the dark, from the facts she has ascertained. In this respect the geologists at Dover took the advice of Hosea Biglow, who wisely advises nobody to prophesy unless he knows. The great advantage of this procedure is that one's prophecies are always certain to come true. 



\section{THE EARTH AND MAN.}

The Story of the Earth and Man. By J. W. Dawson, LL.D., F.R.S., F.G.S., Principal and Vice-Chancellor of McGill University, Montreal. New Edition with Corrections and Additions. With a Colored Diagram and Illustrations. $12 \mathrm{mo}$, Cloth, $\$ 150$.

This little book is, on the whole, the best popular geology that has ever come from the press. The subject is one that possesses the strongest possible interest for the writer and awakens his greatest enthusiasm. One of the strongest and most interesting chapters in the volume is the first of the two on primitive man. The whole book is remarkable for its simplicity, clearness, interest, and vitality.-Mail and Express, N. Y.

The work is full of absorbing interest.-Toledo Blade.

Tle book is a recognized authority on the subject of which it treats, and worthy of a place in the library.-S. S. Journal, N. Y.

We advise any of our readers who have been carried away with the evolution craze-as something that indicates advanced thinking-to read this most valuable work.-Christian Standard, Cincinnati, 0.

An excellent summary of geological history.-Boston Literary World.

The author is an able opponent of the theories of the evolutionists, and his discussion of the theme is interesting. His account of the lowest and earliest form of animal life as exemplified in what he calls the "dawn animal," found by him in fossil state in Canada, is of special interest.-Brooklyn Eagle.

The last two chapters of the work on "Primitive Man" contain an unanswerable argument against the Darwinian theory of evolution, and will be found invaluable by all who are called to face that phase of modern infidelity. We most earnestly commend the volume.-Chicago Interior.

This work has stood the test of criticism, and has won its way to the position of a standard text-book. The learned author does not accept theories for scientific facts, nor permit himself to be led away by mere clamor. He goes to the bottom of things, and gets at the truth if possible. He does not presume to build a scientific system upon finely wrought suppositions. What is known of the history of the earth and man the student will find in this book. It comes up to date with its facts. We do not know its equal as a text-book on this subject. It is sufficiently illustrated, and beautifully printed, and has a copious index.-San Francisco Christian Advocate.

We caunot but give the greatest respect to the writer of this book, who presents so vividly the history of the world's progress, and we cannot but express admiration for that clear and precise style he possesses. $-N$. Y. Tirnes.

\section{Published by HARPER \& BROTHERS, N. Y.}

15F HARPR \& BRoturns will send the above work, postage prepaid, to any part of the United States or Canada, on receipt of the price. 


\section{THE ORIGIN OF THE WORLD.}

\section{The Origin of the World, according to Revelation and Science. By J. W. DAwson, LL.D., F.R.S., F.G.S. $12 \mathrm{mo}$, Cloth, $\$ 200$.}

The revised work is a cyclopædia that will be welcome to all who desire a reconciliation of science and religion, in which the Scriptures retain their authority. The appendices contain valuable scientific criticism, and the treatise meets the controversy as it is to-day.-North American, Philadelphia, $\mathrm{Pa}$.

To all reverent students of the Bible this work will prove a valuable boon in enabling them to determine the precise import of Biblical references to creation, and how these may be harmonized with modern discovery.... In an appendix the volume furnishes several short essays on special points collateral to the general subject, and important to the solution of some of its phases.- - . Y. Evangelist.

Briefly described, the book is a singularly suggestive study of the first chapter of Genesis considered as an inspired revelation in the light of modern science.-Evening Post, N. Y.

The book will commend itself to both scholars and the common people; for, while the latter can understand, the former can enjoy it.-The Churchman, N. Y.

Although most scientists and many theologians will doubtless differ with the author's conclusions, yet he has shown so much ingenuity and care in sustaining them, and is so evidently inspired by a regard for what he desires to be the truth, that his book will command the attention of candid inquirers of whatever shade of belief.-Boston Globe.

Mr. Dawson has devoted much study to the treatment of the subject discussed in this volume. He has sought to get at the truth alone. ... The writer's style is clear and vigorous, and he has patiently wrought out his theories from a wide and comprehensive range of observation.Union-Argus, Brooklyn, N. Y.

The work treats of the mystery of "origins," the beginning; of creation, the "desolate void," the various created objects-light, land, plants, animals, and finally man, whose unity of origin and antiquity are made the subject of two chapters. An appendix, containing short essays on special points, is a valuable feature of the book.-Observer, N. Y.

Whether the reader accepts Dr. Dawson's conclusions or not, he will find the work a wonderfully suggestive study, and singularly fair in its treatment of the opinions and theories it antagonizes.-Free Press, Detroit,Mich.

As a summary of creation, the book is lively and fresh. It will be found interesting and profitable to all students of this alluring theme.Christian Advocale, N.Y.

At least no student of theology can afford not to possess this most excellent work.-Piltsburg Dispatch.

\section{Published by HARPER \& BROTHERS, N. Y.}

29 HАRткв \& Brotilers will send the above work, postage prepaid, to any part of the United States or Canada, on receipt of the price. 



